\title{
ÆUSGS
}

science for a changing world

\section{Colorado Canyons National Conservation Area 2003 Visitor Use Survey - Completion Report}

By Phadrea Ponds, Shana Gillette, and Lynne Koontz, U.S. Geological Survey

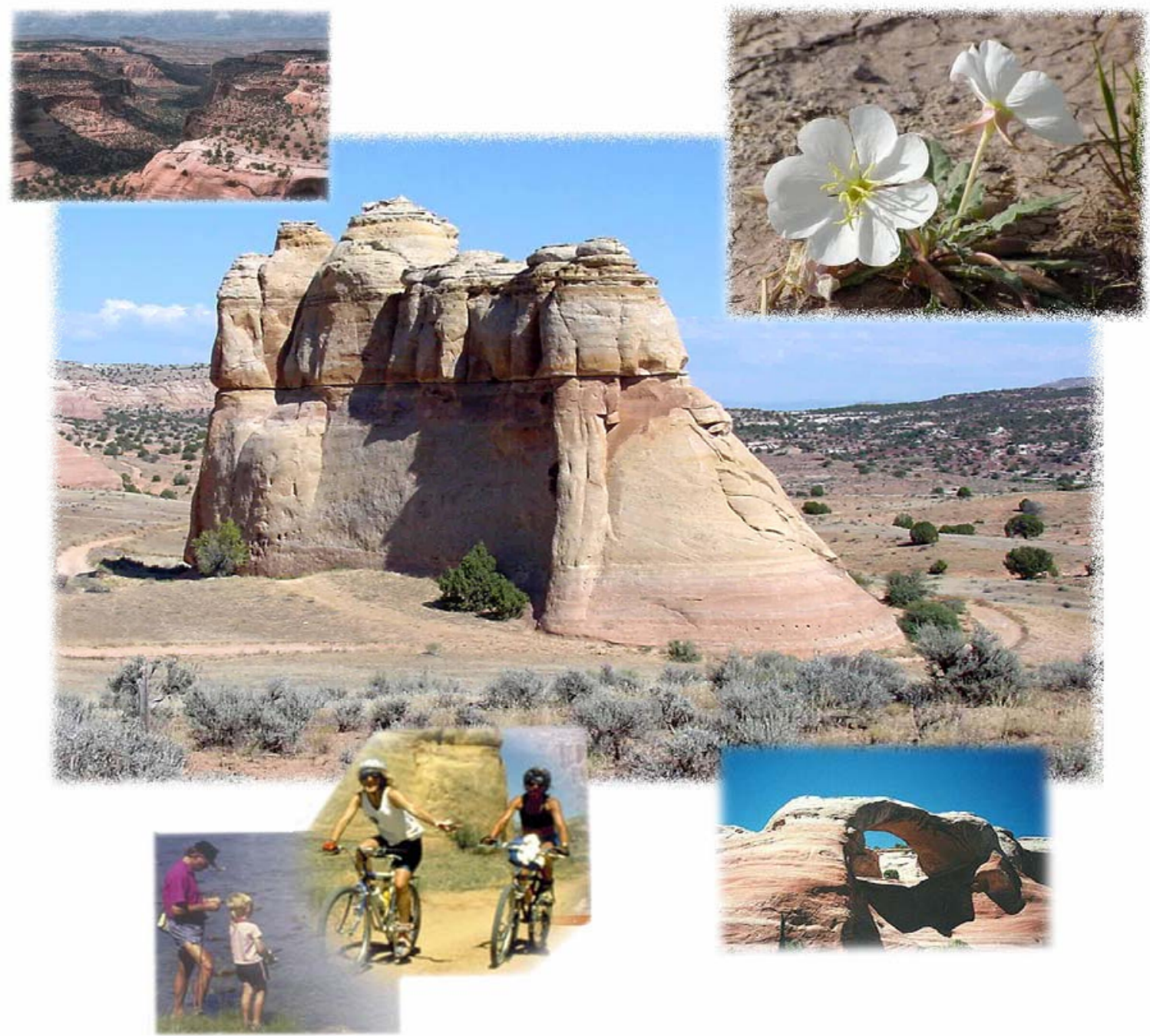

Any use of trade, firm, or product names is for descriptive purposes only and does not imply endorsement by the U.S. Government

\section{Open-File Report 2004-1281}

\section{U.S. Department of the Interior}

U.S. Geological Survey 


\section{Colorado Canyons National Conservation Area 2003 Visitor Use Survey - Completion Report}

By Phadrea Ponds, Shana Gillette, and Lynne Koontz, U.S. Geological Survey

Open-File Report 2004-1281 


\section{U.S. Department of the Interior \\ Gale A. Norton, Secretary}

\section{U.S. Geological Survey \\ Charles G. Groat, Director}

U.S. Geological Survey, Reston, Virginia 2004

For product and ordering information:

World Wide Web: http://www.usgs.gov/pubprod

Telephone: 1-888-ASK-USGS

For more information on the USGS - the Federal source for science about the Earth, its natural and living resources, natural hazards, and the environment:

World Wide Web: http://www.usgs.gov

Telephone: 1-888-ASK-USGS

\section{Suggested citation:}

Ponds, P., S. Gillette, and L. Koontz. 2004. Colorado Canyons National Conservation Area 2003 Visitor Use Survey: completion report. Fort Collins, CO: U.S. Geological Survey. Open-File Report 2004-1281. 68 p.

Although this report is in the public domain, permission must be secured from the individual copyright owners to reproduce any copyrighted material contained within this report. 


\section{Contents}

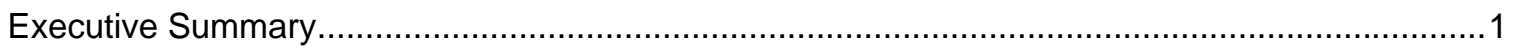

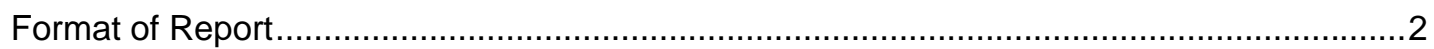

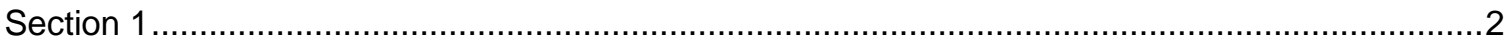

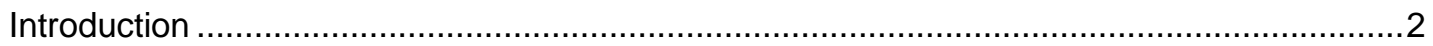

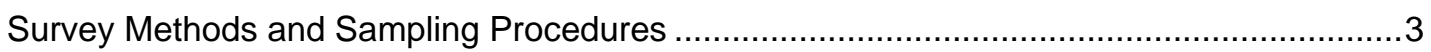

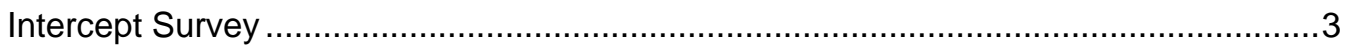

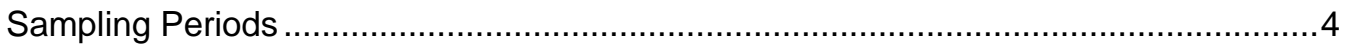

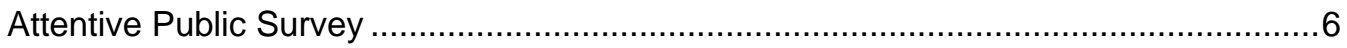

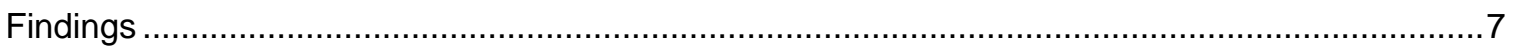

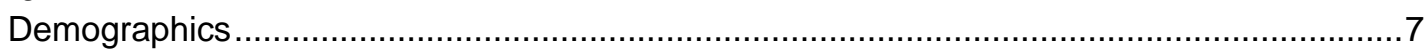

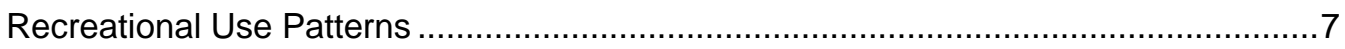

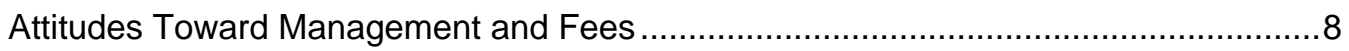

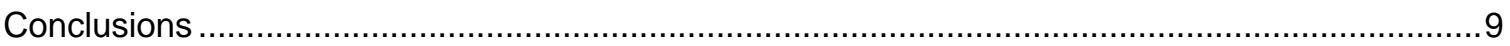

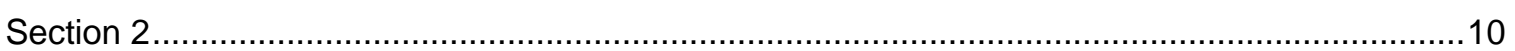

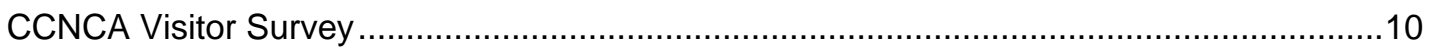

Recreational Profile: Loma, Kokopelli Loops, and Rabbit Valley................................10

Attitudes Toward Management and Fees: Loma, Kokopelli Loops, and

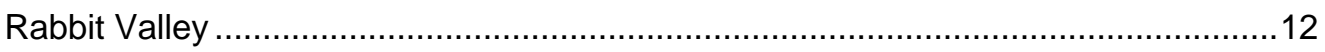

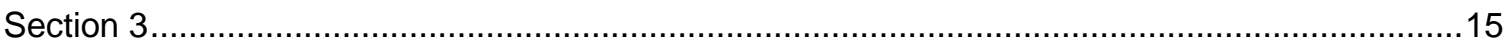

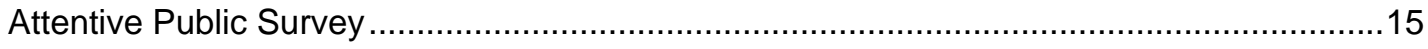

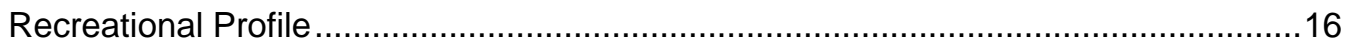

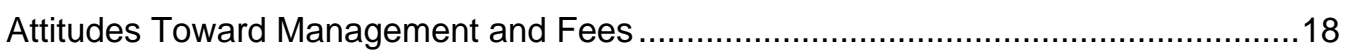

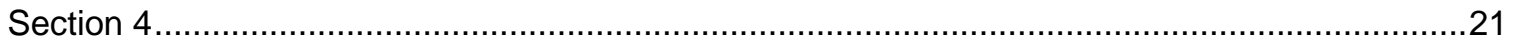

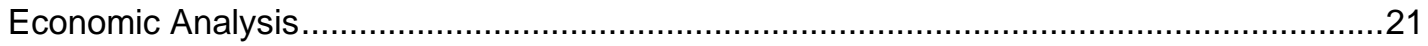

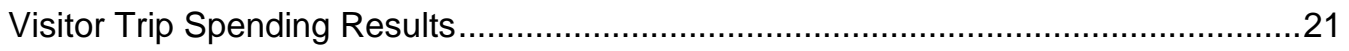

Economic Impacts Associated with Visitor Spending ...........................................23

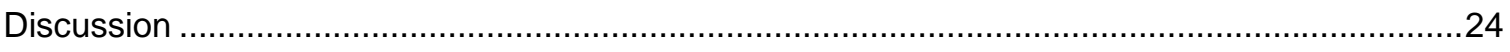

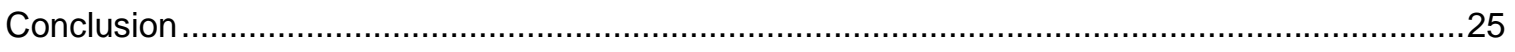

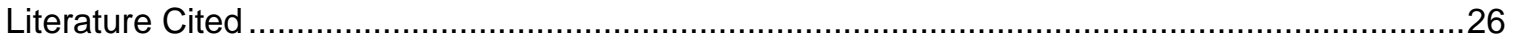

Appendix A - Intercept Survey - Question Summaries ........................................................29

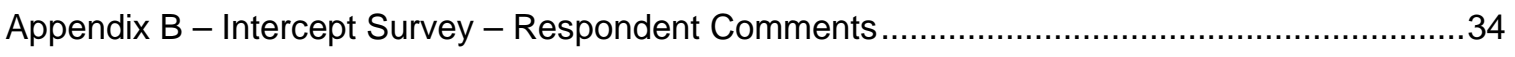

Appendix C - Attentive Public Survey - Question Summaries ..............................................54

Appendix D - Attentive Public Survey - Respondent Comments .............................................62

\section{Figures}

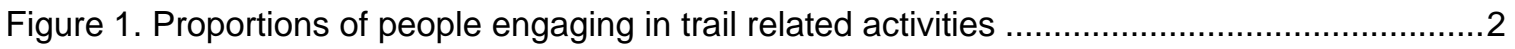

Figure 2. Colorado Canyons Conservation Area and Black Ridge Canons Wilderness.................. 3

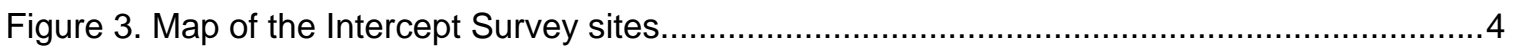




\section{Tables}

Table 1. Response rate for Colorado Canyons National Conservation Area visitor use survey......5

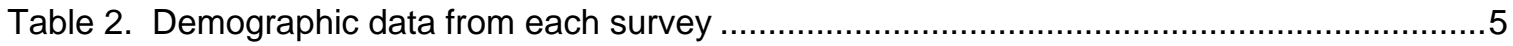

Table 3. Estimates for sample sizes based on different levels of response variation and margins

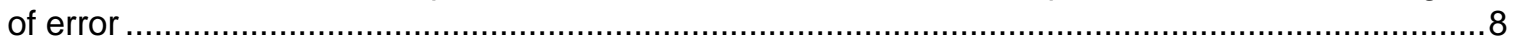

Table 4. Demographic data from each site and the aggregate sample .......................................11

Table 5. Recreational patterns at each site and the aggregate sample ....................................11

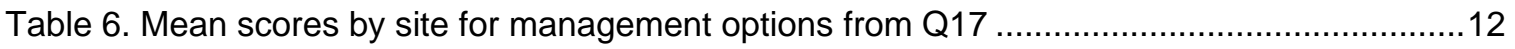

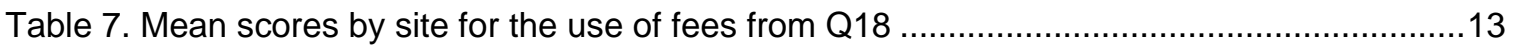

Table 8. Mean scores by site for the type of fees from Q19 ..................................................14

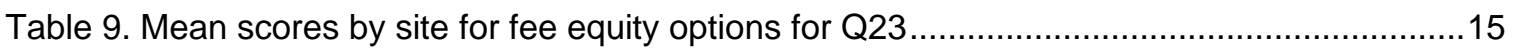

Table 10. Comparison between sites on whether fees would affect visitation from Q22 ..............15

Table 11. Response rate for Colorado Canyons National Conservation Area visitor use survey..16

Table 12. Importance of recreational experiences by respondent characteristics.......................17

Table 13. Distribution of recreational activities by respondent characteristics.............................17

Table 14. Percentages of respondents who agreed that the following management options

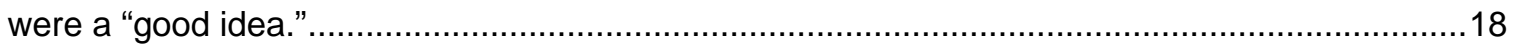

Table 15. Frequency distribution of respondents' willingness toward paying a fee to use

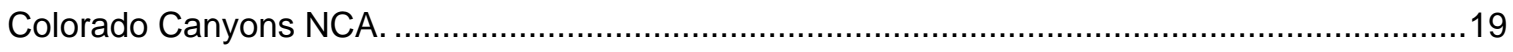

Table 16. Distribution of respondents answering "no" concerning the payment of \$1- 5 fee to

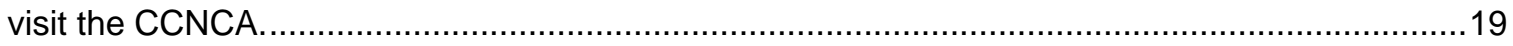

Table 17. Distribution of how monies collected from fees should be spent, as a percentage .......20

Table 18. Percentage of respondents that agreed that the following fee permitting operations

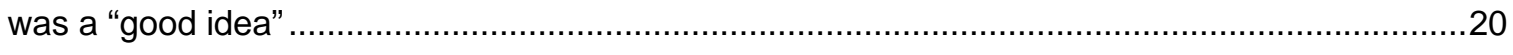

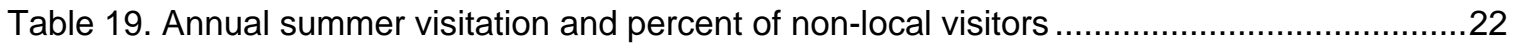

Table 20. Average NCA visitor spending in Mesa County, Colorado ......................................23

Table 21. Total annual spending in Mesa County, Colorado by non-local visitors (in millions of

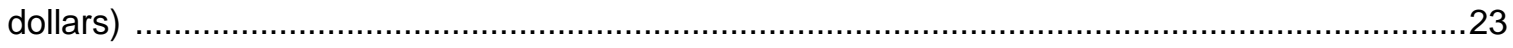

Table 22. Economic impacts of non-local visitor spending in Mesa County, Colorado ................24 


\title{
Colorado Canyons National Conservation Area 2003 Visitor Use Survey - Completion Report
}

\author{
By Phadrea Ponds, Shana Gillette, and Lynne Koontz, U.S. Geological Survey
}

\section{Executive Summary}

This report represents the analysis of research conducted by the U.S. Geological Survey (USGS) for the Bureau of Land Management (BLM). The purpose is to provide socio-economic and recreational use information that can be used in the development of a Resource Management Plan (RMP) for the Colorado Canyons National Conservation Area (CCNCA). The results reported here deal primarily with recreation-based activities in four areas: Kokopelli Loops, Rabbit Valley, Loma Boat Launch, and Devil's Canyon.

In the fall of 2002, researchers from the Policy Analysis and Science Assistance Program (PASA) of the Fort Collins Science Center (FORT) in the USGS met with the staff of the CCNCA to discuss the issues related to social, economic, and human dimensions of natural resource management related to the RMP. As a result, a research study was designed to investigate the recreational experiences of visitors and their attitudes toward the management of the conservation area.

In the spring of 2003, PASA conducted an intercept survey of recreational users at the CCNCA and a mail survey of local residents who were actively involved in decision-making regarding recreation on public lands in Mesa County, Colorado. Two hundred and three (203) mail surveys (66\%) were returned and all of them were completed in full and considered usable. The intercept survey had a response rate with a range from 56\%-64\% among the four sites that were surveyed. We developed a questionnaire (OMB Control Number: 1040-0001) to answer the following questions:

- What are the important differences in citizens' attitudes regarding recreation at the CCNCA?

- What are the factors that explain the differences in attitudes and preferences regarding recreation management of the NCA?

- What are citizens' attitudes and preferences regarding their attitudes about paying a fee to visit the CCNCA?

In general, respondents at all sites reported having an excellent or good recreation experience and almost all indicated that they intended to return. The results from the intercept survey indicated that across four sites ${ }^{1}$ (Kokopelli Loops, Devil's Canyon, Loma Boat Launch, and Rabbit Valley) respondents reported support for undeveloped use and recreation restrictions to limit resource impacts. Respondents indicated that managing sites for undeveloped use was a good idea.

The respondents from the mail survey generally had a positive orientation toward current management practices of the CCNCA. According to our surveys, non-motorized trail related activities were among the three most popular activities people engaged in both close to home and while away. These trail-based recreational activities included walking, running, mountain bike riding, and horseback riding. Research has shown that people participate in these activities for many reasons including learning about nature, exercising, to learning about paleontology, escaping for awhile, and socializing with family and friends (Taylor, 2000). National data indicate that larger percentages of the general American population engage in trail activities than in many other traditional outdoor

\footnotetext{
${ }^{1}$ The response rate at Dinosaur Hill was not significant enough to include in this report.
} 
activities (Cordell, 1999). Over 65\% of people in the U.S. engage in walking as a recreational activity (Figure 1). We found that people wanted to experience the outdoors and the CCNCA provided a good place to do it.

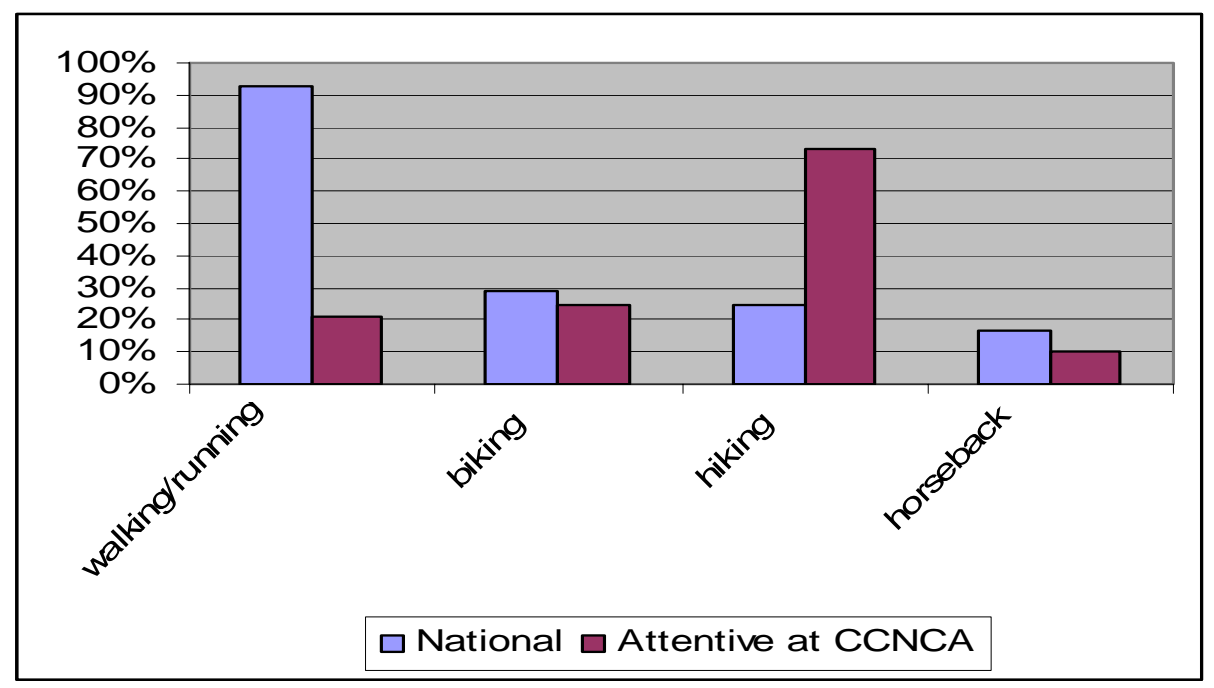

Figure 1. Proportions of people engaging in trail related activities.

Trail activities are often those that people participate in on a regular basis as a way to exercise. This can make trail related activities more attractive from a management standpoint because people who participate in an activity may be more likely to be repeat visitors.

\section{Format of Report}

After the summary and introduction, the report is divided into four sections. Section 1 provides an introductory overview of the project. Section 2 briefly describes the results of the on-site CCNCA Visitor Survey and outlines the issues related to visitor attitudes toward management and fees and acceptance of a hypothetical fee demonstration program at the CCNCA. Section 3 briefly discusses the results of the mail survey and likely effect of proposed management options and proposed fees on visitor use and recreational experiences. Section 4 presents the results of the visitor spending and economic analysis of the on-site survey. The frequency distributions and comments from both surveys are presented in Appendices A through D.

\section{Section 1}

\section{Introduction}

The Colorado Canyons National Conservation Area (CCNCA) is located in Mesa County, Colorado, and Grand County, Utah. This area was found to have unique and valuable scenic, recreational, multiple use opportunities, paleontological, natural, and wildlife components along with wilderness value that are worthy of additional protection. The CCNCA is comprised of 122,300 rugged acres of sandstone canyons, natural arches, spires, and alcoves carved into the Colorado Plateau along a 24-mile stretch of the Colorado River. Included in the CCNCA are 75,550 acres of wilderness designated as the Black Ridge Canyons Wilderness and at the western boundary of the CCNCA, 5,200 acres stretch into eastern Utah (Figure 2). The area contains an array of opportunities for many outdoor recreational activities anywhere from wilderness backpacking to off-highway vehicle (OHV) activities. 


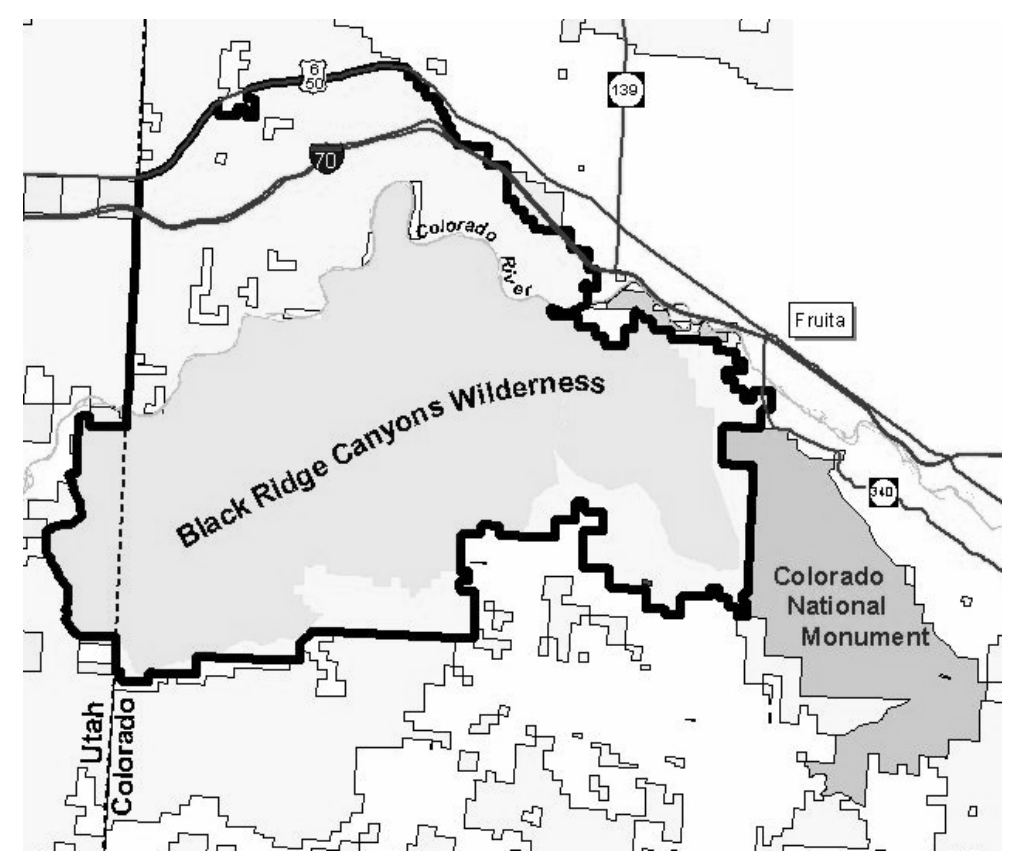

Figure 2. Colorado Canyons Conservation Area and Black Ridge Canyons Wilderness. ${ }^{2}$

The purpose of this study was to investigate the recreational experiences of visitors and their attitudes toward the management of the conservation area. To this end, we conducted an intercept survey of recreational users at the CCNCA and a mail survey of the "attentive public" (a select group of citizens who participated in public planning process regarding recreation on public lands in Mesa County between 2001 and 2003).

\section{Survey Methods and Sampling Procedures}

Administration of both surveys followed a modified Dillman (2000) procedure that included handing intercept surveys out at specified sites in the CCNCA, initial and subsequent follow-up mailings. A pretest of the questionnaires was conducted with a small sample of students and recreational users at Colorado State University to clarify instructions and wording on survey instruments. The questionnaires and sampling designs then went through a revision and peer review process as required by the USGS.

\section{Intercept Survey}

The CCNCA visitor survey of the recreational user public was designed to provide input from members of the general public who recreate at the CCNCA. The visitation estimates were calculated from the monthly totals of laser counts of vehicles at Rabbit Valley, Loma, and Kokopelli Loops and from laser counts of individuals at Devils Canyon in 2003 (Figure 3).

${ }^{2}$ Retrieved April 19, 2004, from http://www.co.blm.gov/colocanyons/ccncalandsmap.htm 


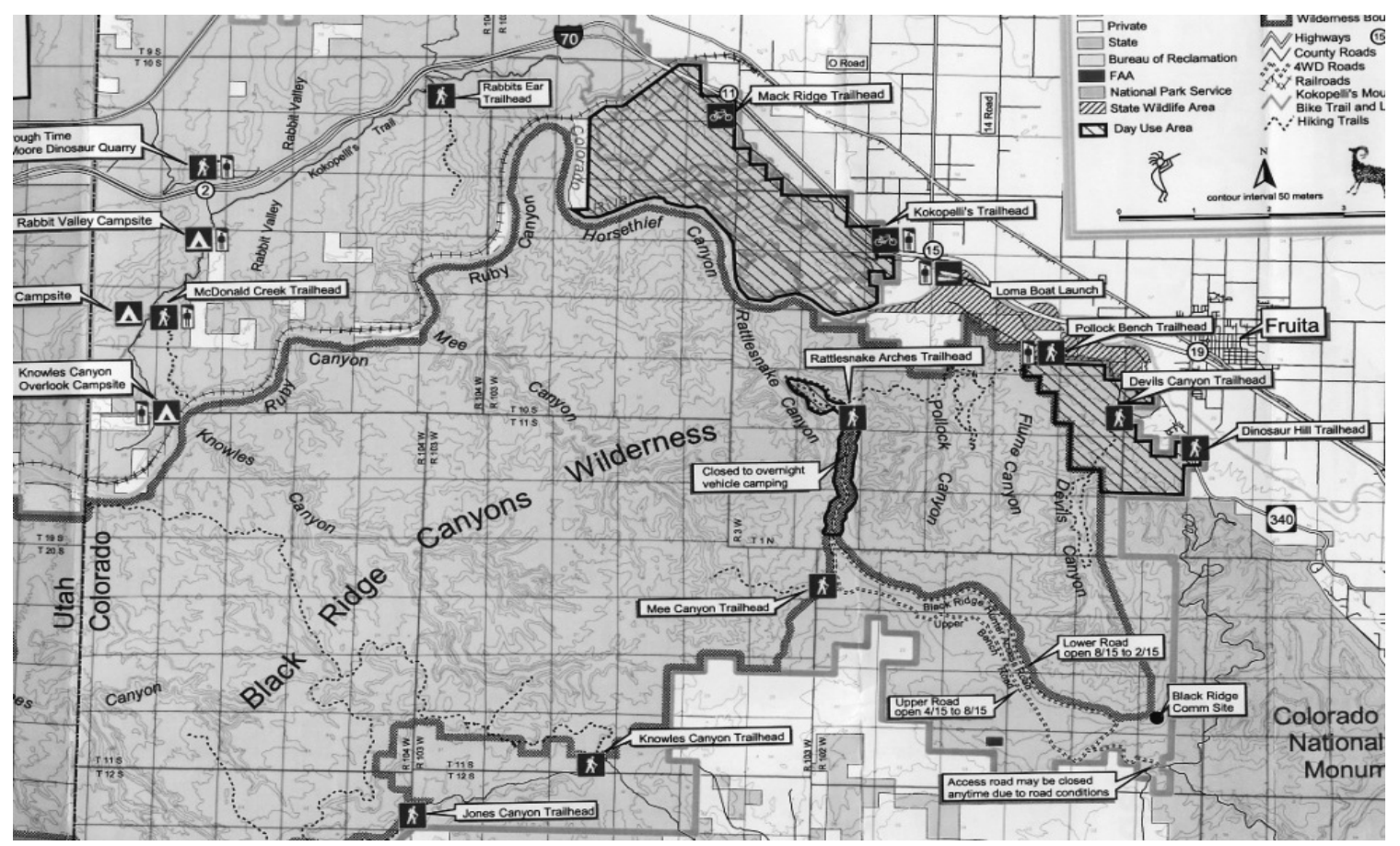

Figure 3. Map of the Intercept Survey sites. ${ }^{3}$

In order to obtain a composite profile of the CCNCA visitor population, a multiple frame approach was used. Five main recreational areas were selected within the CCNCA from which to sample. The population sample estimates were then combined at each site to arrive at a general population estimate1. Table 1 presents two sampling designs for the visitor population, based on different criteria for margins of error and response variation (Rea and Parker, 1997, Dillman, 2000). These differences in turn are based on frame population sizes and recreational use patterns. Due to smaller size of the other two sites, Devils Canyon and Dinosaur Hill were sampled at a higher margin of error, but with a 50/50 variance due to the homogenous user profiles of both sites (Table 1).

Response rates were good at all sites except Dinosaur Hill. Loma was a bit lower than the expected 65\%, but the other sites were very close to the expected return rate, achieving samples that were statistically significant (Table 2). Because Dinosaur Hill was so difficult to sample due to the erratic nature of visitor use of the site, the sample received was not significant and thus not included in the analysis. Frequency distributions of Dinosaur Hill responses are included in Appendix D.

\section{Sampling Periods}

Intercept surveys were handed out to visitors to the CCNCA during the peak spring visitation period (midMarch to mid-June in all sampling frames except Loma Boat Launch where visitation peaks in the months of June and July). The days and times that surveyors were at the five sites varied in order to achieve a good representation of recreational user activity. To disseminate surveys, surveyors intercepted users at the trailhead. Given the dispersed nature of Rabbit Valley recreationists, surveyors intercepted recreationists in their vehicles as they left or entered the site. Usually, one survey was handed to one member of a recreation group if it was a family, if more than one member of a family took the survey, it was noted on the intercept survey sheet and recorded in the data analysis if more than one survey came from one household. If the group was a group of friends, everyone received the survey.

${ }^{3}$ Source: CCNCA visitor map and brochure. 
Table 1. Estimates for sample sizes based on different levels of response variation and margins of error.

\begin{tabular}{|c|c|c|c|c|c|c|}
\hline \multicolumn{7}{|c|}{ Estimated sampling sizes } \\
\hline Sample frames & $\begin{array}{l}\text { Recreational uses } \\
\text { in CCNCA } \\
\text { recreational areas }\end{array}$ & $\begin{array}{c}\text { Estimated } \\
\text { spring } \\
\text { visitor } \\
\text { population }\end{array}$ & $\begin{array}{c}\text { Sample size } \\
80 / 50 \text { variance } \\
5 \% \text { margin of error }\end{array}$ & $\begin{array}{c}\text { Surveys } \\
\text { handed } \\
\text { out }\end{array}$ & $\begin{array}{l}\text { Surveys } \\
\text { received }\end{array}$ & $\begin{array}{c}\text { Response } \\
\text { rate }(\%)\end{array}$ \\
\hline Rabbit Valley & $\begin{array}{c}\text { OHVs, } \\
\text { motorcycles, } \\
\text { mountain-biking, } \\
\text { horseback riding, } \\
\text { hiking, camping }\end{array}$ & 20,000 & 243 & 375 & 235 & 63 \\
\hline Kokopelli Loops & $\begin{array}{l}\text { Mountain-biking, } \\
\text { horseback riding }\end{array}$ & 35,000 & 243 & 375 & 229 & 61 \\
\hline Loma Boat Launch & Water activities & 12,000 & 240 & 370 & 209 & 56 \\
\hline \multicolumn{7}{|c|}{ Estimated sampling frames } \\
\hline Sample frames & $\begin{array}{c}\text { Primary } \\
\text { recreational uses }\end{array}$ & $\begin{array}{l}\text { Estimated } \\
\text { spring } \\
\text { visitor } \\
\text { population } \\
\end{array}$ & $\begin{array}{c}\text { Sample size } \\
50 / 50 \text { variance } \\
10 \% \text { margin of error }\end{array}$ & $\begin{array}{c}\text { Surveys } \\
\text { handed } \\
\text { out } \\
\end{array}$ & $\begin{array}{l}\text { Surveys } \\
\text { received }\end{array}$ & $\begin{array}{c}\text { Response } \\
\text { rate }(\%) \\
\end{array}$ \\
\hline Devils Canyon & $\begin{array}{l}\text { Horseback-riding, } \\
\text { hiking }\end{array}$ & $5,000-8,000$ & 95 & 145 & 93 & $64 \%$ \\
\hline Dinosaur Hill & Hiking & 3,000 & 94 & 120 & 40 & $33 \%$ \\
\hline
\end{tabular}

Table 2. Response rate for Colorado Canyons National Conservation Area visitor use survey.

\begin{tabular}{|l|c|c|c|c|c|}
\hline & \multirow{5}{*}{$\begin{array}{c}\text { Attentive public } \\
\text { survey }\end{array}$} & \multicolumn{5}{|c|}{ CCNCA Visitor's Survey } \\
\cline { 3 - 7 } & Rabbit Valley & Loma & Kokopelli Loops & Devil's Canyon \\
\hline Sample size & 400 & 375 & 370 & 375 & 145 \\
Respondents & 203 & 235 & 209 & 229 & 93 \\
Response rate (\%) & 66 & 63 & 56 & & 61 \\
\hline
\end{tabular}

The purpose of the survey and the importance of its results to future management of the CCNCA were explained to the visitor. Visitors were also informed that their participation was voluntary. Incentives were provided in the form of bottles of cold ice water and CCNCA posters. People were thanked for their co-operation and asked to fill out their responses at the end of the visit and mail back the survey (a stamped, self-addressed envelope was provided). The participant's address was recorded at the time the survey was handed out to allow for follow-up of non-respondents. Based on some earlier surveys in this region, a response rate of $65 \%$ or higher was expected. ${ }^{4}$

\section{Efforts to Increase the Response Rate}

- The questionnaire was an easy-to-read, 6-page magazine format that took about 12 minutes to complete for non-residents. Residents could skip certain travel cost questions, which made the survey shorter to complete.

${ }^{4}$ The 2002 NAU Colorado Canyon National Conservation Area Visitor Study received slightly lower response rates with an intercept survey in the same area. 
- The interview team members were trained in the administration of the interview protocol, including procedures to increase the effectiveness of respondent communications, before they handed out the survey instrument. A well-trained survey team helped decrease non-response error by effectively communicating the survey's purpose and the BLM's desire for input from all recreational users.

- In order to encourage response, the BLM staff provided the incentive of CCNCA posters and cold bottled water.

\section{Attentive Public Survey}

A mail-back questionnaire was sent to local residents and others who had attended a BLM public meeting or who had been actively involved in decision-making processes regarding recreation on public lands in Mesa County, Colorado within the past two years as determined by the BLM staff. The target response goal was 280 usable surveys for this group.

This survey employed fixed alternative questions plus space for comments. The respondents were queried about their attitudes in the form of responses to potential ecosystem management practices. Technical terms and management strategies were developed and evaluated in conjunction with natural resource managers who were partners in this study. Data were collected using a non-probability sampling method described by Parker and Rea (1997). With non-probability sampling, population elements are selected on the basis of their availability (e.g., because they volunteered) or because of the researcher's personal judgment that they are representative. The consequence is that an unknown portion of the population is excluded (e.g., those who did not volunteer). One of the most common types of non-probability sample is called a convenience sample - not because such samples are necessarily easy to recruit, but because the researcher uses whatever individuals are available rather than selecting from the entire population (Babbie, 1975).

For the attentive public survey we used a mailing list, consisting of 400 names, provided to us by the BLM Grand Junction Field Office. This list consisted of members of the local communities and other people who had attended a BLM public meeting or were actively involved in decision-making processes regarding recreation on public lands in Mesa County, Colorado within the past two years. Several studies have looked at the difference between the general and attentive publics (Pierce and others, 1982: Lamb and Cline, 2003). These studies have found that the attentive public is composed of individuals who are more likely to have direct personal experience in dealing with recreation management issues, tend to be members of civic organizations, and are more frequently involved in policy issues that might help shape public opinion. Although there were many more people who could have been identified as having concerns or opinions regarding the management of the CCNCA, this list of respondents were of key interest and were accessible given the time are resources available. The respondents were not meant to be representative of the larger population potentially affected by CCNCA management strategies, rather they were selected to obtain a view of the ranges of attitudes regarding recreation management. Because some members of the population had no chance of being sampled, the extent to which this sample actually represents the entire population cannot be known. Therefore this data is not intended to be representative or generalizable of the members of the local community.

The survey instrument was administered as a mail survey. We anticipated a deliverable rate of $95 \%$ (useable addresses). The results of the mail survey were expected to provide us with input from the "attentive public" and to determine if there are differences in fee attitudes between members of the general public who recreate on public lands and members of the "attentive public" who are actively involved in decision-making regarding recreation on public lands.

Following the Tailored Design Method (Dillman, 2000), a cover letter accompanied the survey explaining the purpose and goals of the study, and requesting participation. The survey instrument was mailed by the staff at the BLM Grand Junction field office and received by PASA. For the purposes of confidentiality, all connections between respondent address and identification number were eliminated when completed questionnaires were received. No lists of respondent addresses were retained after data collection was completed. Respondent address lists, return envelopes, and address labels were disposed of by shredding. Only the identification number was recorded in the database. These efforts expected to yield a response rate of at least $70 \%$. A total of 203 respondents completed and returned the survey for a response rate of $66 \%$ (Table 2). 
The data were analyzed through the use of SPSS®11.0. In order to meet the stated objectives of our study plan, we subjected the data to a series of comparative analyses. Data analysis began with descriptive statistics to display the responses from the respondents. Parametric, nonparametric and cross tabulations were performed to identify any major differences or similarities in the responses to survey questions. The use of means, distribution, cross-tabulations, etc. provided information about program areas that are being considered as possible fee demonstration sites. One objective of the attentive public survey was to obtain rough indicators of relative acceptance of proposed management strategies. The general trends discovered can be used to assist the CCNCA recreation planners and staff with the development of the alternative strategies for the RMP. This research can also benefit management by providing an understanding of current public attitudes about events and preferences for management alternatives that may be related to the benefits of a fee demonstration program. This research could be used to enhance the ability of resource managers to forecast changes in public sentiment, in turn, improving mutually beneficial relationships between the agency and stakeholders. The managers and planners will be able to use the results of this survey to focus their attention on resources and areas addressed in their RMP.

The mail survey was not intended to generalize an entire population; it was designed to provide information that will help the BLM meet the requirements of their RMP process. However, from these results, managers will be aware of the concerns of an attentive public, people who have an active interest in the CCNCA, and that public's response to proposed management actions and their preferences for resource conditions.

\section{Findings}

\section{Demographics}

CCNCA Visitor Survey - recreational users were similar in their income distribution and work status while differing in age, gender, education, and the number of people in a household.

- Kokopelli Loops had the youngest age distribution, Loma the most equal split of older and younger respondents, and Rabbit Valley the greatest percentage of respondents over 50. Kokopelli Loops had the largest percentage of young male, nonresident respondents with college degrees or higher who reported one-person households. Rabbit Valley had the largest percentage of local respondents and Loma had the largest number of respondents reporting a household of 3 or more people.

- The Devils Canyon respondents were predominately local, with a mean age and income similar to that of other sites. Age groups were split almost equally between the 35-49 age range and 50 and above. Respondents were predominately female, not retired, college graduates, and part of a two-person household.

Attentive Public Survey - respondents were predominately middle-aged males (mean age of 53.5 years). More than two thirds of the respondents were self-reported as being residents of Mesa County, CO (Grand Junction, Fruita, etc.). Incomes varied widely, the self reported mean income was $\$ 55,000$ annually (Table 3).

\section{Recreational Use Patterns}

CCNCA Visitor Survey - the majority of respondents across sites reported having an excellent or good experience. The travel distance and time spent recreating differed significantly among sites.

- A large majority of respondents at Kokopelli Loops, Loma, and Rabbit Valley reported having an excellent or good experience recreating and almost all indicated that they intended to return. The majority of users reported visiting a site $1-3$ times in the last 12 months. 
Table 3. Demographic data from each survey.

\begin{tabular}{|c|c|c|c|c|c|}
\hline \multirow[b]{3}{*}{$\begin{array}{l}\text { Median age } \\
\text { Median income }\end{array}$} & \multirow[b]{2}{*}{$\begin{array}{c}\text { Attentive } \\
\text { public survey }\end{array}$} & \multicolumn{4}{|c|}{ CCNCA Visitor's Survey } \\
\hline & & $\begin{array}{l}\text { Rabbit } \\
\text { Valley }\end{array}$ & Loma & $\begin{array}{c}\text { Kokopelli } \\
\text { Loops }\end{array}$ & $\begin{array}{l}\text { Devil's } \\
\text { Canyon }\end{array}$ \\
\hline & $\begin{array}{r}54 \\
\$ 70,289 \\
\end{array}$ & $\begin{array}{r}44 \\
\$ 75,283 \\
\end{array}$ & $\begin{array}{c}42 \\
\$ 68,678 \\
\end{array}$ & $\begin{array}{r}39 \\
78,938 \\
\end{array}$ & $\begin{array}{r}49 \\
62,500 \\
\end{array}$ \\
\hline \multicolumn{6}{|c|}{$\begin{array}{l}\text { The following responses are reported as percentages }(\%) \text { unless otherwise noted. Also note that frequencies may be less than } \\
100 \% \text { because of non-response. }\end{array}$} \\
\hline Gender & $(n=196)$ & $(n=225)$ & $(\mathrm{n}=200)$ & $(n=229)$ & $(n=92)$ \\
\hline $\begin{array}{l}\text { Male } \\
\text { Female }\end{array}$ & $\begin{array}{l}73 \\
27\end{array}$ & $\begin{array}{l}57 \\
43\end{array}$ & $\begin{array}{l}59 \\
41\end{array}$ & $\begin{array}{l}73 \\
27\end{array}$ & $\begin{array}{l}40 \\
60\end{array}$ \\
\hline Level of education & $(n=196)$ & $(n=228)$ & $(n=195)$ & $(n=226)$ & $(\mathrm{n}=91)$ \\
\hline $\begin{array}{l}\text { High school or less } \\
\text { Some college/Associate Degree } \\
\text { College Graduate or Post-graduate degree }\end{array}$ & $\begin{array}{c}6 \\
21 \\
73\end{array}$ & $\begin{array}{c}1 \\
14 \\
58\end{array}$ & $\begin{array}{c}1 \\
6 \\
69\end{array}$ & $\begin{array}{c}2 \\
2 \\
78\end{array}$ & $\begin{array}{c}1 \\
14 \\
63\end{array}$ \\
\hline Income & $(\mathrm{n}=154)$ & $(\mathrm{n}=203)$ & $(\mathrm{n}=188)$ & $(\mathrm{n}=213)$ & $(\mathrm{n}=83)$ \\
\hline $\begin{array}{l}\text { Less than } \$ 24,999 \\
\$ 25,000-\$ 49,999 \\
\$ 50,000-\$ 74,999 \\
\$ 75,000-\$ 99,999 \\
\text { More than } \$ 100,000\end{array}$ & $\begin{array}{l}12 \\
31 \\
58 \\
15 \\
38\end{array}$ & $\begin{array}{l}10 \\
30 \\
24 \\
13 \\
24\end{array}$ & $\begin{array}{l}13 \\
25 \\
20 \\
19 \\
15\end{array}$ & $\begin{array}{l}12 \\
22 \\
25 \\
19 \\
21\end{array}$ & $\begin{array}{l}14 \\
29 \\
33 \\
12 \\
12\end{array}$ \\
\hline
\end{tabular}

- There is a significant difference among sites with regard to travel distance and time spent recreating. Kokopelli Loops respondents reported traveling farther and recreating longer than respondents at other sites. The Rabbit Valley recreational pattern differs significantly from the other two sites in that there are opportunities for more multi-use activities and it includes users from a larger region.

- At Devils Canyon, more than $95 \%$ of recreational users reported their intent to return, with $75 \%$ fewer respondents reporting that their recreational experience was excellent or good. Due to the proximity of the site to a residential area, use patterns are predominately local, frequent, and between two-three hours in duration.

Attentive Public Survey - although there were no significant differences among the respondents.

- $\quad$ Close to half of the respondents traveled less than 2 hours, one way, to reach their recreational site. One quarter traveled between 3 and 5 hours, while the remaining $25 \%$ travel more than 6 hours to reach their recreational site.

- $\quad 88 \%$ reported that their recreational experience was either excellent or good.

- More than three quarters of the respondents reported that they were able to enjoy physical exercise in a natural environment. And $82 \%$ said that the time at their chosen recreational site allowed them to get away from a developed setting to a natural setting. Almost all $(95 \%)$ indicated that they would return to the site.

\section{Attitudes Toward Management and Fees}

CCNCA Visitor Survey - willingness to pay a fee varied between sites while support for undeveloped use was evident across sites.

- At the Loma and Kokopelli Loops sites, more than $70 \%$ of the respondents were willing to pay a fee (of the fee ranges presented). However, at Rabbit Valley where there were more local respondents, there was slightly less willingness to pay a fee and at Devils Canyon, where the majority of users were local and it is near a residential area, less than half (around 45\%) were willing to pay a fee. 
- Respondents at Kokopelli Loops, Loma, and Rabbit Valley reported support for undeveloped use and recreation restrictions to limit resource impacts. Across sites, respondents indicated that not developing any facilities, and managing sites for undeveloped use was a good idea. Respondents at all sites also indicated that restricting recreation to limit impact on rare plants and wildlife species was a good idea. Differences appeared in management options that included some degree of development action. There are significant differences between sites regarding developing for more recreational experiences, trails, and day use.

- Across sites, respondents noted that guided tours of the area were a bad idea while using fees for education/interpretive materials (such as maps and brochures), toilets, and maintenance for roads and trails was a good idea. Respondents at all sites registered even greater support for wildlife protection, indicating that it was a good idea.

- No significant differences were found among sites regarding fee equity for low-income recreational users. Overall, respondents indicated that it was a good idea to not assess a fee on weekdays or on select weekends.

- No significant differences were found between sites in regards to recreational displacement if a fee were imposed. Slightly more than half of all respondents reported that they would continue to visit as often if a fee were implemented at the site. Devils Canyon respondents were fairly evenly distributed between the three possibilities on the affect of fees on visitation. Almost $30 \%$ would continue to visit, while slightly more than $30 \%$ would visit less often or would go recreate at another location and/or do some other activity.

Attentive Public Survey - the majority of the respondents were willing to pay a fee, however there were several caveats linked to this willingness - such as wanting the managing agency to receive the fees and the monies should be spent to manage and protect the resources of the area.

- Nearly three-quarters of the attentive public survey respondents indicated that they thought that it is a good idea to spend monies collected from fees on wildlife/habitat protection, dinosaur/fossil protection, educational materials, law enforcement, toilets and parking, and roads and trails.

- A total of 107 out of 203 attentive survey respondents were willing to pay a small fee (between \$1-5) to use NCA. Responses of willingness to pay $\$ 1, \$ 2, \$ 3$, or $\$ 4$ accounted for $90 \%$ of all respondents.

\section{Conclusions}

This study was conducted to seek information about the perceptions and experiences of visitors to the CCNCA and sought to identify future recreation and visitation patterns. The results from the surveys reflect the visitor's direct experiences at the CCNCA. Managers can use this information to develop a range of management options associated with visitor use and natural resource management.

What should managers and land-use planners take from these results? First, our research has highlighted that people prefer collective activities like spending time with friends, families, equally as well as time alone to experience the landscape (Taylor and others, 1999; Ponds, 2000). Managers could highlight the places and landscapes, described by this research, that provide opportunities for family-related activities, as well as opportunities for spending time alone. Next, this information allows managers to develop management plans that include quality of life, sense of place, and recreation resource management referred to in the BLM's priorities for recreation and visitor services (see BLM Work Plan FY2003-2007). By doing this, managers and planners will be able to provide quality experiences for people who have varying degrees of attachments to the resource.

There are two messages that emerge from this study: one is that finding strategies that engage people, encourage partnerships, and elevate the idea of public service requires multiple efforts, combining different means of discovering the values that ensure a quality experience and enjoyment of natural and cultural resources on public lands. Value of place and quality of life are critical elements to consider when making land and resource decisions, these values are especially sensitive to changes imposed on the landscape. 
The second message is that, people who are more engaged in the landscape tend to be more critically concerned with its maintenance, and more likely to have factored the environment into their decision to choose the locale, in this case the CCNCA, as their place of preferred recreation. Schreyer and Knopf (1984) suggested that individuals with a strong place attachment serve as reliable indicators of place quality for a variety of user groups.

Finally, this type of research can serve as a useful tool for identifying individuals or groups who ought to be included in public involvement processes. One of the most important roles for the agency is to establish mechanisms to listen to citizen concerns. Community residents and visitors can contribute invaluable knowledge about local, ecological, societal, and economical perspective to the discussion of natural resource management. Integrating this type of knowledge into resource planning and management would represent a significant shift in the natural resource and land management philosophy, because it would recognize that people are an integral part of ecological systems.

\section{Section 2}

\section{CCNCA Visitor Survey}

\section{Recreational Profile: Loma, Kokopelli Loops, and Rabbit Valley}

\section{Demographic Description}

Differences in age, number in household, and education were found to be significant between sites. Kokopelli Loops had the youngest age distribution, Loma the most equal split of older and younger respondents, and Rabbit Valley the greatest percentage of respondents over 50. The differences in income distribution between Rabbit Valley and Kokopelli Loops respondents were not significant, nor were differences in work status-most respondents were not retired. There were significant differences between sites in residency, education, the number of people in a household, and residency. Kokopelli Loops had the largest percentage of male, nonresident respondents with college degrees or higher who reported one-person households. Loma had the largest number of respondents reporting a household of three or more people. Rabbit Valley had the largest number of respondents who live within Mesa County, Colorado and/or within 65 miles of the CCNCA sites. A comparison of demographics across sites is presented in the Table 4 below.

\section{Recreational Use Pattern}

There is a significant difference between sites with regards to travel distance and time spent recreating. Kokopelli Loops respondents reported traveling farther and recreating longer than respondents at other sites. The Rabbit Valley recreational pattern differs significantly from the other two sites in that there are opportunities for more multi-use activities and includes users from a larger region. The largest percentage of respondents traveling less than 100 miles was at Rabbit Valley. Motorcycle/OHV riding, mountain bike riding, and hiking were the three main activities reported at Rabbit Valley while Kokopelli Loops respondents listed mountain biking as their primary main activity and Loma respondents listed kayaking and rafting. A large majority of respondents at all sites reported having an excellent or good experience recreating and almost all indicated that they intended to return. The range in number of visits was the same across sites, some respondents reported visiting for the first time while the majority has visited the site 1-3 times in the last 12 months. A comparison of recreational patterns between sites is presented in Table 5 below. 
Table 4. Demographic data from each site and the aggregate sample.

\begin{tabular}{|c|c|c|c|c|}
\hline & Rabbit Valley & Loma & Kokopelli Loops & All three sites \\
\hline Median age & 43 & 42 & 39 & 42 \\
\hline Median income & $\$ 75,283.25$ & $\$ 68,678.19$ & $\$ 78,938.97$ & $\$ 74,516.56$ \\
\hline $\begin{array}{l}\text { Age groups }{ }^{\mathrm{a}} \\
\text { Below } 35 \\
35-49 \\
50 \text { and above }\end{array}$ & $\begin{array}{c}29.7 \% \\
34.7 \\
35.6\end{array}$ & $\begin{array}{c}26.2 \% \\
45.6 \\
28.2\end{array}$ & $\begin{array}{c}33.9 \% \\
52.0 \\
14.1\end{array}$ & $\begin{array}{c}30.1 \% \\
44.1 \\
25.8\end{array}$ \\
\hline $\begin{array}{l}\text { Income levels } \\
\text { Below } \$ 40,000 \\
\$ 40,000-\$ 69,000 \\
\$ 70,000 \text { and above }\end{array}$ & $\begin{array}{l}21.2 \\
41.9 \\
36.9\end{array}$ & $\begin{array}{l}22.3 \\
39.4 \\
38.3\end{array}$ & $\begin{array}{l}18.3 \\
39.0 \\
42.7\end{array}$ & $\begin{array}{l}20.5 \\
40.1 \\
39.4\end{array}$ \\
\hline $\begin{array}{l}\text { Non-local (residing more than } 65 \\
\text { miles away from the site) }{ }^{\mathrm{a}}\end{array}$ & 58.7 & 67.7 & 87.0 & 71.4 \\
\hline Male $^{\mathrm{b}}$ & 57.3 & 59.0 & 72.9 & 63.3 \\
\hline Not retired & 87.6 & 93.0 & 91.1 & 91.4 \\
\hline $\begin{array}{l}\text { College graduate or } \\
\text { Post-graduate degree }^{a}\end{array}$ & 58.4 & 69.5 & 78.3 & 65.9 \\
\hline $\begin{array}{l}\text { Number in household } \\
1 \text { person } \\
2 \text { people } \\
3 \text { people or more }\end{array}$ & $\begin{array}{l}18.0 \\
42.8 \\
39.2\end{array}$ & $\begin{array}{l}15.4 \\
32.8 \\
51.8\end{array}$ & $\begin{array}{l}24.0 \\
44.0 \\
32.0\end{array}$ & $\begin{array}{l}19.3 \\
40.2 \\
40.5\end{array}$ \\
\hline
\end{tabular}

${ }^{\mathrm{a}} P<.000$

${ }^{\mathrm{b}} \mathrm{P}<.001$

Table 5. Recreational patterns at each site and the aggregate sample.

\begin{tabular}{|c|c|c|c|c|}
\hline & Rabbit Valley & Loma & Kokopelli Loops & All three sites \\
\hline Mean travel distance & 152.53 & 165.96 & 257.82 & 193.21 \\
\hline Mean number of visits in 12 months & 3.13 & 3.76 & 5.09 & 4.01 \\
\hline Mean number of hours recreated & 2.28 & 1.60 & 2.12 & 2.02 \\
\hline $\begin{array}{l}\text { Travel distance }^{\mathrm{a}} \\
\text { Less than } 100 \\
100-199 \\
200-299 \\
300 \text { and above }\end{array}$ & $\begin{array}{l}47.0 \% \\
17.2 \\
20.7 \\
15.2\end{array}$ & $\begin{array}{l}42.6 \% \\
13.8 \\
29.8 \\
13.8\end{array}$ & $\begin{array}{l}16.7 \% \\
18.6 \\
46.1 \\
18.6\end{array}$ & $\begin{array}{l}35.1 \% \\
16.6 \\
32.4 \\
15.9\end{array}$ \\
\hline $\begin{array}{l}\text { Number of times visited } \\
1-3 \\
4-6 \\
7 \text { or more }\end{array}$ & $\begin{array}{l}68.4 \\
11.4 \\
8.8\end{array}$ & $\begin{array}{l}71.2 \\
17.8 \\
11.0\end{array}$ & $\begin{array}{l}74.1 \\
11.1 \\
14.8\end{array}$ & $\begin{array}{l}74.2 \\
13.8 \\
12.0\end{array}$ \\
\hline $\begin{array}{l}\text { Hours recreated }^{\mathrm{a}} \\
2 \text { or less } \\
3-8 \\
9 \text { and up }\end{array}$ & $\begin{array}{l}11.0 \\
49.3 \\
39.6\end{array}$ & $\begin{array}{l}51.3 \\
37.4 \\
11.3\end{array}$ & $\begin{array}{l}14.4 \\
59.0 \\
26.6\end{array}$ & $\begin{array}{l}24.3 \\
49.2 \\
26.5\end{array}$ \\
\hline Most important activity $^{\mathrm{a}}$ & $\begin{array}{l}\text { Day hiking, mountain } \\
\text { biking } \\
\text { Motorcycle/OHV } \\
62.7\end{array}$ & $\begin{array}{l}\text { Rafting/ } \\
\text { kayaking } \\
72.1\end{array}$ & $\begin{array}{l}\text { Mountain biking } \\
89.6\end{array}$ & $\begin{array}{l}\text { Kayaking/rafting or } \\
\text { mountain biking } \\
63.9\end{array}$ \\
\hline Excellent/good recreational experience & 93.7 & 87.0 & 99.6 & 93.7 \\
\hline Intend to return & 98.2 & 93.8 & 99.6 & 98.9 \\
\hline
\end{tabular}

${ }^{\mathrm{a}} \mathrm{P}<.000$ 


\section{Attitudes Toward Management and Fees: Loma, Kokopelli Loops, and Rabbit Valley}

\section{Management Options}

In a one-way analysis of variance (ANOVA) of management options, there are significant differences between sites regarding developing more recreational experiences, developing trails, and developing day use areas. On average, respondents at all sites reported support for undeveloped use and recreation restrictions to limit resource impacts. Across sites, respondents indicated that not developing any facilities, and managing sites for undeveloped use was a good idea. Respondents at all sites also indicated that restricting recreation to limit impact on rare plants and wildlife species was a good idea. Differences appeared in management options that included some degree of development action. Respondents differed in their support of developing "recreational experience opportunities". Rabbit Valley registered less support for that option than Loma and Kokopelli Loops. Respondents also differed in their support of trail development for motorized off-road vehicle trail loops. Kokopelli Loops and Loma respondents reported that such development was a bad idea while Rabbit Valley respondents were more mixed, leaning more toward support. Day use areas were supported more by Kokopelli Loops respondents than respondents from Rabbit Valley or Loma. In written comments, Kokopelli Loops respondents mentioned the need for potable water, more sun shelters and perhaps more toilets. A comparison of mean scores is presented in Table 6 below.

Table 6. Mean scores by site for management options from 017.

"Listed below are a few management options for Rabbit Valley. Please circle the number that indicates what you think about the following options." [range: "1"very good idea - "4" very bad idea]

\begin{tabular}{|c|c|c|c|c|c|c|}
\hline & & Devmore $^{a}$ & Nodev & Restrict & Devtrail $^{a}$ & Dayuse $^{a}$ \\
\hline \multirow[t]{2}{*}{ Kokopelli Loops } & Mean & 2.55 & 2.00 & 2.25 & 3.44 & 2.61 \\
\hline & $\begin{array}{l}\mathrm{N} \\
\text { Standard } \\
\text { deviation }\end{array}$ & $\begin{array}{l}228 \\
.994\end{array}$ & $\begin{array}{l}227 \\
.984\end{array}$ & $\begin{array}{l}228 \\
.892\end{array}$ & $\begin{array}{l}232 \\
.919\end{array}$ & $\begin{array}{l}229 \\
.860\end{array}$ \\
\hline \multirow[t]{2}{*}{ Loma } & Mean & 2.93 & 2.11 & 2.40 & 3.56 & 2.33 \\
\hline & $\begin{array}{l}\mathrm{N} \\
\text { Standard } \\
\text { deviation }\end{array}$ & $\begin{array}{c}199 \\
1.144\end{array}$ & $\begin{array}{c}202 \\
1.168\end{array}$ & $\begin{array}{c}201 \\
1.059\end{array}$ & $\begin{array}{l}202 \\
.972\end{array}$ & $\begin{array}{l}203 \\
.913\end{array}$ \\
\hline \multirow[t]{2}{*}{ Rabbit Valley } & Mean & 2.52 & 2.22 & 2.25 & 2.51 & 2.26 \\
\hline & $\begin{array}{l}\mathrm{N} \\
\text { Standard } \\
\text { deviation }\end{array}$ & $\begin{array}{c}220 \\
1.062\end{array}$ & $\begin{array}{c}218 \\
1.006\end{array}$ & $\begin{array}{c}219 \\
1.051\end{array}$ & $\begin{array}{c}220 \\
1.214\end{array}$ & $\begin{array}{l}219 \\
.864\end{array}$ \\
\hline \multirow[t]{2}{*}{ Total } & Mean & 2.66 & 2.11 & 2.30 & 3.17 & 2.40 \\
\hline & $\begin{array}{l}\mathrm{N} \\
\text { Standard } \\
\text { deviation }\end{array}$ & $\begin{array}{r}647 \\
1.079 \\
\end{array}$ & $\begin{array}{r}647 \\
1.054 \\
\end{array}$ & $\begin{array}{c}648 \\
1.002\end{array}$ & $\begin{array}{r}654 \\
1.141\end{array}$ & $\begin{array}{l}651 \\
.890\end{array}$ \\
\hline & & & & & & \\
\hline
\end{tabular}




\section{Options for Using Fees}

In a one-way analysis of variance (ANOVA) of options for using fees, there are significant differences between sites regarding the use of fees for law enforcement, camping areas, and the protection of dinosaur fossils and cultural resources (such as prehistoric rock art and historical buildings). Across sites, respondents noted that guided tours of the area were a bad idea while using fees for education/interpretive materials (such as maps and brochures), toilets, and maintenance for roads and trails was a good idea. Respondents at all sites registered even greater support for wildlife protection, indicating, on average, that it was a good idea. Kokopelli Loops respondents indicated greater support for using fees to subsidize camping areas with some written comments indicating that either primitive campsites or passes to the state park would be preferred options. Support for using fees on the protection of dinosaur fossils and cultural resources differed in part because of the presence of either at the site. Kokopelli Loops and Rabbit Valley respondents, on average, indicated that protecting fossil and cultural resources was a very good idea, while Loma respondents were less supportive. A comparison of mean scores is presented in Table 7 below.

Table 7. Mean scores by site for the use of fees from 018.

"If fees were collected at Rabbit Valley, the money could be used in a number of ways. Please circle the number that indicates what you think about the following options." [range: "1"very good idea - "4" very bad idea]

\begin{tabular}{|c|c|c|c|c|c|c|c|c|c|c|}
\hline Site & & Educ & Tours & Toilet & Road & Lawenf $^{a}$ & $\begin{array}{l}\text { Camp } \\
\text { areas }^{\mathrm{b}}\end{array}$ & $\begin{array}{c}\text { Wild } \\
\text { pro }\end{array}$ & Dinopro $^{\mathrm{a}}$ & $\begin{array}{c}\text { Cultural } \\
\text { resources }^{\mathrm{a}}\end{array}$ \\
\hline \multirow[t]{2}{*}{ Kokopelli Loops } & Mean & 2.34 & 3.12 & 2.10 & 1.89 & 2.83 & 2.48 & 1.80 & 1.76 & 1.80 \\
\hline & $\begin{array}{l}\mathrm{N} \\
\text { Standard } \\
\text { deviation }\end{array}$ & $\begin{array}{l}223 \\
.822\end{array}$ & $\begin{array}{l}224 \\
.816\end{array}$ & $\begin{array}{l}228 \\
.804\end{array}$ & $\begin{array}{l}227 \\
.733\end{array}$ & $\begin{array}{l}223 \\
.970\end{array}$ & $\begin{array}{l}227 \\
.928\end{array}$ & $\begin{array}{l}226 \\
.766\end{array}$ & $\begin{array}{l}225 \\
.860\end{array}$ & $\begin{array}{l}224 \\
.871\end{array}$ \\
\hline \multirow[t]{2}{*}{ Loma } & Mean & 2.43 & 3.25 & 2.04 & 2.16 & 2.73 & 2.37 & 1.86 & 2.00 & 2.05 \\
\hline & $\begin{array}{l}\mathrm{N} \\
\text { Standard } \\
\text { deviation }\end{array}$ & $\begin{array}{l}198 \\
.979\end{array}$ & $\begin{array}{l}199 \\
.982\end{array}$ & $\begin{array}{c}201 \\
1.001\end{array}$ & $\begin{array}{l}199 \\
.918\end{array}$ & $\begin{array}{c}197 \\
1.094\end{array}$ & $\begin{array}{c}200 \\
1.029\end{array}$ & $\begin{array}{l}198 \\
.943\end{array}$ & $\begin{array}{c}199 \\
1.110\end{array}$ & $\begin{array}{c}202 \\
1.218\end{array}$ \\
\hline \multirow[t]{2}{*}{ Rabbit Valley } & Mean & 2.17 & 3.15 & 2.14 & 1.99 & 2.45 & 2.16 & 1.75 & 1.56 & 1.59 \\
\hline & $\begin{array}{l}\mathrm{N} \\
\text { Standard } \\
\text { deviation }\end{array}$ & $\begin{array}{l}217 \\
.863\end{array}$ & $\begin{array}{l}214 \\
.826\end{array}$ & $\begin{array}{l}224 \\
.939\end{array}$ & $\begin{array}{l}220 \\
.924\end{array}$ & $\begin{array}{r}216 \\
1.046\end{array}$ & $\begin{array}{l}222 \\
.862\end{array}$ & $\begin{array}{l}222 \\
.912\end{array}$ & $\begin{array}{l}223 \\
.768\end{array}$ & $\begin{array}{l}223 \\
.833\end{array}$ \\
\hline \multirow[t]{2}{*}{ Total } & Mean & 2.31 & 3.17 & 2.10 & 2.01 & 2.67 & 2.34 & 1.80 & 1.76 & 1.81 \\
\hline & $\begin{array}{l}\mathrm{N} \\
\text { Standard } \\
\text { deviation }\end{array}$ & $\begin{array}{l}638 \\
.892\end{array}$ & $\begin{array}{l}637 \\
.874\end{array}$ & $\begin{array}{l}653 \\
.914\end{array}$ & $\begin{array}{l}646 \\
.865\end{array}$ & $\begin{array}{c}636 \\
1.047\end{array}$ & $\begin{array}{l}649 \\
.947\end{array}$ & $\begin{array}{l}646 \\
.874\end{array}$ & $\begin{array}{l}647 \\
.932\end{array}$ & 649 \\
\hline
\end{tabular}

$\mathrm{a}_{\mathrm{P}}<.000$

${ }^{\mathrm{b}} \mathrm{P}<.001$

Educ: Educational and interpretive materials such as maps

Toilet: Toilets and parking

Lawenf: Law enforcement

Wildpro: Wildlife and habitat protection

Cultural Resources: Protection of cultural resources such as historical buildings

and prehistoric art

\section{Options for the Types of Fees}

Across sites, no significance difference was found on preferences for fee types. On average, respondents at all sites supported the different types of fees proposed and indicated that they would be a good idea. Some respondents $(<5 \%)$ did not respond to this question and many instead wrote "No Fees!" in large letters across the question. Other respondents added comments to help explain their choices. These written comments are provided in Appendix (B). A comparison of mean scores is presented in Table 8 below.
Tours: Guided tours of the area

Road: Road and trail maintenance

Campareas: Camping areas

Dinopro: protection of dinosaur fossil locations 
Table 8. Mean scores by site for the type of fees from 019.

"What do you think about fee-permitting options at Rabbit Valley? Please circle the number that indicates what you think." [range: "1"very good idea - "4" very bad idea]

\begin{tabular}{|c|c|c|c|c|c|c|c|c|}
\hline & & feestay & feeres & ncapass & feehiuse & feerec & blmpass & fedpass \\
\hline \multirow[t]{2}{*}{ Kokopelli Loops } & Mean & 2.22 & 2.55 & 2.25 & 2.63 & 2.08 & 2.07 & 2.12 \\
\hline & $\begin{array}{l}\mathrm{N} \\
\text { Standard } \\
\text { deviation }\end{array}$ & $\begin{array}{l}225 \\
.889\end{array}$ & $\begin{array}{l}226 \\
.971\end{array}$ & $\begin{array}{l}222 \\
.907\end{array}$ & $\begin{array}{l}224 \\
.938\end{array}$ & $\begin{array}{l}224 \\
.900\end{array}$ & $\begin{array}{l}222 \\
.970\end{array}$ & $\begin{array}{l}216 \\
.992\end{array}$ \\
\hline \multirow[t]{2}{*}{ Loma } & Mean & 2.32 & 2.66 & 2.35 & 2.68 & 2.27 & 2.25 & 2.26 \\
\hline & $\begin{array}{l}\mathrm{N} \\
\text { Standard } \\
\text { deviation }\end{array}$ & $\begin{array}{c}198 \\
1.020\end{array}$ & $\begin{array}{c}197 \\
1.001\end{array}$ & $\begin{array}{c}194 \\
1.044\end{array}$ & $\begin{array}{l}196 \\
.973\end{array}$ & $\begin{array}{l}197 \\
.972\end{array}$ & $\begin{array}{c}199 \\
1.047\end{array}$ & $\begin{array}{r}195 \\
1.088\end{array}$ \\
\hline \multirow[t]{2}{*}{ Rabbit Valley } & Mean & 2.10 & 2.66 & 2.19 & 2.60 & 2.26 & 2.11 & 2.12 \\
\hline & $\begin{array}{l}\mathrm{N} \\
\text { Standard } \\
\text { deviation }\end{array}$ & $\begin{array}{l}218 \\
.908\end{array}$ & $\begin{array}{l}221 \\
.943\end{array}$ & $\begin{array}{l}217 \\
.936\end{array}$ & $\begin{array}{l}220 \\
.904\end{array}$ & $\begin{array}{l}220 \\
.948\end{array}$ & $\begin{array}{l}219 \\
.968\end{array}$ & $\begin{array}{l}219 \\
.967\end{array}$ \\
\hline \multirow[t]{2}{*}{ Total } & Mean & 2.21 & 2.62 & 2.26 & 2.63 & 2.20 & 2.14 & 2.17 \\
\hline & $\begin{array}{l}\mathrm{N} \\
\text { Standard } \\
\text { deviation }\end{array}$ & $\begin{array}{l}641 \\
.940 \\
\end{array}$ & $\begin{array}{l}644 \\
.970 \\
\end{array}$ & $\begin{array}{l}633 \\
.961 \\
\end{array}$ & $\begin{array}{l}640 \\
.937 \\
\end{array}$ & $\begin{array}{l}641 \\
.942 \\
\end{array}$ & $\begin{array}{l}640 \\
.995 \\
\end{array}$ & $\begin{array}{r}630 \\
1.015 \\
\end{array}$ \\
\hline
\end{tabular}

Feestay: Different fees for different lengths of recreational stay (for example, a week versus a day).

Feeres: Different fees for residents vs. non-residents

Ncapass: An annual pass that includes the Colorado National Monument and the Colorado Canyons National Conservation Area.

Feehiuse: An entrance fee for high-use periods such as holidays and weekends.

Feerec: A fee for specific recreation use, such as the use of camping sites.

Blmpass: An annual pass that would allow you to visit all BLM locations as often as you would like.

Fedpass: An annual pass for all of the areas within the region managed by different federal agencies (e.g., U.S. Fish and Wildlife Service,

National Park Service, and the BLM).

\section{Fee Equity}

No significant differences were found among sites regarding fee equity for low-income recreational users. Overall, respondents indicated that it was a good idea to not assess a fee on weekdays or on select weekends. As with the other fee question, some respondents chose not to respond to this question and instead wrote "No Fees!" across the question. Other respondents took the time to provide other suggestions that they thought might be feasible as well as their thoughts on fee equity. These written comments are provided in the Appendix. A comparison of mean scores is presented in Table 9 below.

\section{Recreational Displacement}

No significant differences were found between sites in regards to recreational displacement if a fee were imposed. Slightly more than half of all respondents reported that they would continue to visit as often if a fee were implemented at the site. An almost equal percentage of respondents report that they would either visit less often $(22.5 \%)$ or go somewhere else/do something else (24.6\%). A comparison between sites is presented in Table 10 below. 
Table 9. Mean scores by site for fee equity options for 023 .

"If a fee were collected at Rabbit Valley, people with a limited income may stop visiting this location. The BLM would like to know which fee options would allow people with a limited income to continue to visit Rabbit valley. Please circle the number that indicates what you think about the following options" [range: "1"very good idea - "4" very bad idea]

\begin{tabular}{|c|c|c|c|}
\hline & & nofeewk & nofeewknd \\
\hline \multirow[t]{3}{*}{ Kokopelli Loops } & Mean & 1.99 & 2.16 \\
\hline & $\mathrm{N}$ & 195 & 194 \\
\hline & Standard deviation & .969 & .946 \\
\hline \multirow[t]{3}{*}{ Loma } & Mean & 2.15 & 2.16 \\
\hline & $\mathrm{N}$ & 174 & 173 \\
\hline & Standard deviation & .997 & .998 \\
\hline \multirow[t]{3}{*}{ Rabbit Valley } & Mean & 2.03 & 1.96 \\
\hline & $\mathrm{N}$ & 182 & 182 \\
\hline & Standard deviation & .907 & .885 \\
\hline \multirow[t]{3}{*}{ Total } & Mean & 2.05 & 2.09 \\
\hline & $\mathrm{N}$ & 551 & 549 \\
\hline & Standard deviation & .959 & .947 \\
\hline
\end{tabular}

Nofeewk: No fees would be charged on weekdays

Nofeewknd: No fees would be charged on selected weekends

Table 10. Comparison between sites on whether fees would affect visitation from 022.

"If the BLM collected a recreation fee at Rabbit Valley, how likely would the fee affect your visits to Rabbit Valley in the future?"

\begin{tabular}{|l|c|c|c|c|}
\hline \multicolumn{1}{|c|}{ Options } & Rabbit Valley (\%) & Loma (\%) & Kokopelli Loops (\%) & All sites (\%) \\
\hline Continue to visit as often if fee & 44.7 & 58.9 & 54.9 & 52.9 \\
\hline Would visit less often if fee & 27.4 & 20.8 & 19.6 & 22.5 \\
\hline Would go / do something else & 27.9 & 20.3 & 25.5 & 24.6 \\
\hline
\end{tabular}

\section{Section 3}

\section{Attentive Public Survey}

In addition to the primary objective of the overall study, the attentive public survey also investigated: (1) visitors' preferences regarding visitor use and recreational experiences at the CCNCA, (2) the important differences between local and non-local residents regarding their attitudes about the management of the CCNCA and; (3) the important difference between local and non-local regarding their attitudes about paying a fee to visit the CCNCA.

In the spring of 2003 we sent a questionnaire ${ }^{5}$ by mail to 400 potential respondents who had attended BLM public meetings, within the past two years, or were actively involved in decision-making regarding recreation on public lands in Mesa County, Colorado. A total of 203 respondents completed and returned the survey for a response rate of $66 \%$ (Table 11) which is above the minimum response rate of 50\% called for by Dillman (2000). Response rates ranged from just $75 \%$ of Mesa County Residents (local) to $25 \%$ of Non-Residents (non-local). These analyses

\footnotetext{
${ }^{5}$ Approval to conduct the survey was obtained through the formal OMB approval process (OMB Control Number 1040-0001.
} 
separate the visitor into two groups: local and non-local visitors. The division reflects the likelihood that local visitors would have a different propensity to visit a near area than non-local visitors pursuing other recreation activities. The assessments presented in this section generally focus on the relationship between the local and nonlocal visitor.

Table 11. Response rate for Colorado Canyons National Conservation Area visitor use survey.

\begin{tabular}{|l|c|}
\hline Total addresses & 400 \\
\hline Undeliverable addresses & 91 \\
\hline Respondents & 203 \\
\hline Response rate & $66 \%$ \\
\hline
\end{tabular}

This section of the report provides a recreational profile and a summary of responses from the attentive public survey. Please note that frequencies may range from $99 \%$ to $101 \%$ due to rounding.

\section{Recreational Profile}

Questionnaire results are presented in sections beginning with a descriptive approach to survey respondents, moving to a comparison of respondent characteristics, then proceeding to focused questions designed to understand willingness to pay user fees, as well as perceived impacts and general opinions about recreation and resource management. A complete listing of all survey data is given in Appendix C.

Demographic Description - in general, a majority of the respondents were males (73\%), middle-aged (mean age of 53.5 years), and well educated (73\% had a college or post-graduate degree). Two thirds of the respondents $(75 \%)$ are self-reported as being residents of Mesa County, Colorado (Grand Junction, Fruita, etc.). Incomes varied widely, the self reported mean income was \$55,000 annually (Appendix C).

Recreational Use Patterns - a variety of researchers have explored the emotional attachments, feelings, and personal experiences that people have about specific places or landscapes (Mitchell and others, 1991; Rasker and Glick, 1994; Purcell and others, 1994; Taylor and others, 1995, 1999, 2000; Ponds, 2001; Warzecha and Lime, 2001). A close relationship between humans and their surroundings often leads to an attachment to important places that ultimately hold special meaning or value (Warzecha and Lime, 2001). The concept of sense of place in environmental management represents an integral component of ecosystem management, because it recognizes that people are a part of ecosystems; and that human pursuit of past, present, and future desires, needs, and values (including perceptions, beliefs, values, and behaviors) influences ecosystem management (Cordell et al. 1999). Cordell and his colleagues go further to suggest that in principle and practice, contemporary ecosystem management should consider physical, emotional, mental, spiritual, social, cultural, and economic well being (Cordell and others, 1999).

Most visitors come to the area to slow down/relax and get way from the city to an undeveloped area (83\%), enjoy physical exercise in natural environment (91\%). On average the respondents reported that being able to experience the environment in a setting such as the CCNCA was very important to their recreational experiences. There was not a significant enough difference between the visitors in each category to report here. Table 12 shows the percentages of the responses in each category.

In some of our previous research on the Colorado Plateau, for example, local residents and "old timers" had issues with new comers coming into the area and "messing up everything" (Ponds, 2001). All of the respondents seemed to have a healthy respect for the environment and wanted to preserve it for future generations.

Recreational and use patterns were consistent between both groups as well. Most of the respondents live in the area and acknowledged the CCNCA as being a part of their "backyard." This is a place where they can enjoy everyday activities such as walking, running, bike riding, etc. There was not a noticeable concern among local residents about non-locals using the area for recreational purposes (Table 13). 
Table 12. Importance of recreational experiences by respondent characteristics.

\begin{tabular}{|c|c|c|c|c|c|c|c|}
\hline Importance of experience & $\begin{array}{c}\text { Male } \\
(\%)\end{array}$ & $\begin{array}{c}\text { Female } \\
(\%)\end{array}$ & $\begin{array}{c}\text { Mesa County } \\
\text { resident } \\
(\%) \\
\end{array}$ & $\begin{array}{c}\text { Non- } \\
\text { resident } \\
(\%) \\
\end{array}$ & $\begin{array}{c}\text { Retired } \\
(\%)\end{array}$ & $\begin{array}{c}\text { Not } \\
\text { Retired } \\
(\%) \\
\end{array}$ & Total $(\%)$ \\
\hline $\begin{array}{l}\text { Able to enjoy physical exercise in a } \\
\text { natural environment }\end{array}$ & 75 & 87 & 7 & 0 & 74 & 81 & 91 \\
\hline $\begin{array}{l}\text { Helped me to slow down and relax for a } \\
\text { while }\end{array}$ & 67 & 83 & 73 & 63 & 52 & 80 & 83 \\
\hline $\begin{array}{l}\text { Helped me to better understand the } \\
\text { environment and the history of the area }\end{array}$ & 61 & 46 & 56 & 29 & 63 & 56 & 82 \\
\hline $\begin{array}{l}\text { Able to be active in a dynamic setting } \\
\text { instead of reading about it }\end{array}$ & 72 & 73 & 75 & 62 & 70 & 75 & 79 \\
\hline $\begin{array}{l}\text { Allowed me to enjoy a range of physical } \\
\text { challenges }\end{array}$ & 52 & 50 & 56 & 40 & 55 & 51 & 77 \\
\hline $\begin{array}{l}\text { I was able to share this experience with my } \\
\text { family }\end{array}$ & 54 & 64 & 61 & 40 & 57 & 57 & 65 \\
\hline It was intellectually stimulating & 39 & 39 & 38 & 39 & 39 & 40 & 62 \\
\hline $\begin{array}{l}\text { Allowed me to get away from a developed } \\
\text { setting to a natural environment }\end{array}$ & 81 & 90 & 13 & 15 & 81 & 85 & 60 \\
\hline $\begin{array}{l}\text { I did something here that I've never done } \\
\text { before }\end{array}$ & 9 & 25 & 11 & 21 & 7 & 17 & 55 \\
\hline
\end{tabular}

Table 13. Distribution of recreational activities by respondent characteristics.

\begin{tabular}{|c|c|c|c|c|c|c|}
\hline & $\begin{array}{c}\text { Male } \\
(\%)\end{array}$ & $\begin{array}{c}\text { Female } \\
(\%)\end{array}$ & $\begin{array}{c}\text { Mesa County } \\
\text { resident } \\
(\%)\end{array}$ & $\begin{array}{c}\text { Non- } \\
\text { residential } \\
(\%)\end{array}$ & $\begin{array}{c}\text { Retired } \\
(\%)\end{array}$ & $\begin{array}{c}\text { Not } \\
\text { Retired } \\
(\%) \\
\end{array}$ \\
\hline Day hiking & 73 & 79 & 77 & 65 & 82 & 72 \\
\hline Walking/running & 19 & 27 & 22 & 19 & 14 & 24 \\
\hline Picnicking & 23 & 17 & 21 & 27 & 24 & 21 \\
\hline Mountain bike riding & 29 & 14 & 23 & 25 & 19 & 31 \\
\hline Motorcycle/OHV riding & 8 & 10 & 10 & 4 & 7 & 8 \\
\hline Backpacking/backcountry & 18 & 12 & 11 & 29 & 7 & 21 \\
\hline Camping near vehicles & 12 & 6 & 11 & 17 & 2 & 1 \\
\hline Horseback riding & 8 & 19 & 13 & 4 & 16 & 8 \\
\hline Tubing & 3 & 2 & 2 & 6 & 3 & 3 \\
\hline Kayaking/rafting & 28 & 25 & 22 & 40 & 15 & 33 \\
\hline Fishing & 8 & 6 & 8 & 6 & 0 & 11 \\
\hline Sunbathing & 6 & 10 & 5 & 13 & 9 & 3 \\
\hline Viewing fossils or rock art & 30 & 48 & 34 & 35 & 31 & 37 \\
\hline Wildlife watching & 54 & 44 & 50 & 50 & 55 & 50 \\
\hline Scenery & 69 & 56 & 69 & 54 & 81 & 59 \\
\hline Photography & 46 & 48 & 43 & 54 & 47 & 47 \\
\hline Motor boating & 3 & 6 & 4 & 4 & 0 & 6 \\
\hline Hunting camp & 4 & 4 & 4 & 4 & 0 & 6 \\
\hline
\end{tabular}




\section{Attitudes Toward Management and Fees}

Management Options - regarding management options for the CCNCA, more than half of the respondents were in favor of not developing any facilities and that recreation in the area should be restricted to limit the impacts on rare plants and wildlife species (Table 14). The largest percentage of respondents indicated that not developing any facilities, and managing the area for undeveloped use was a good idea. In a written comment one respondent stated:

"The BLM is a crucial and very important entity in the preservation and protection of our natural lands. It is our increasing perception that the emphasis for the BLM and many lands in Colorado is a bias to development and more intensive and inappropriate uses and activities on these lands. It seems the needs for short term exploitation or inappropriate uses such as off-road vehicles is taking precedent over the need for long term balanced preservation and appropriate human activities on these lands. We are active users of recreational low impact visitation to these lands and it seems most of the citizens of this state would agree with this. Often more local and intrusive users are given too much influence over these decisions. These lands belong to all not just those whom by reason of geography or location may be closer to these areas" (Appendix D).

Respondents differed in their support for day use areas. Non-residents were more supportive of adding picnic areas, toilets, and camping areas for day camping. Local respondents were less in favor of these types of amenities (Table 14). Local respondents indicated greater support for limiting the amount of recreational opportunities (65\%) and motorized vehicle use in the area (79\%). One responded suggested the following in their written comment:

"Restrict the number of motorized conveniences. While mountain bikes are mechanized they are quiet. Put the 4-wheelers out at the Go-Kart track east of GJ. Don't let Rabbit Valley be the Yellowstone of ATVs!" (Appendix D)

Table 14. Percentages of respondents who agreed that the following management options were a "good idea."

\begin{tabular}{|c|c|c|c|c|c|c|}
\hline & $\begin{array}{c}\text { Male } \\
(\%)\end{array}$ & $\begin{array}{c}\text { Female } \\
(\%)\end{array}$ & $\begin{array}{l}\text { Mesa County } \\
\text { resident } \\
(\%) \\
\end{array}$ & $\begin{array}{l}\text { Non- } \\
\text { resident } \\
(\%)\end{array}$ & $\begin{array}{c}\text { Retired } \\
(\%)\end{array}$ & $\begin{array}{c}\text { Not } \\
\text { Retired } \\
(\%) \\
\end{array}$ \\
\hline $\begin{array}{l}\text { Developing more recreational opportunities } \\
\text { at this location }\end{array}$ & 35 & 17 & 34 & 22 & 34 & 29 \\
\hline $\begin{array}{l}\text { Not developing any facilities, and manage } \\
\text { this area for undeveloped use only }\end{array}$ & 57 & 65 & 49 & 83 & 53 & 62 \\
\hline $\begin{array}{l}\text { Restrict recreation in this area to limit } \\
\text { impact on rare plants and wildlife species }\end{array}$ & 55 & 71 & 55 & 71 & 61 & 58 \\
\hline $\begin{array}{l}\text { Develop a series of motorized off-road } \\
\text { vehicle trail loops, managing for all-terrain } \\
\text { vehicles and motorcycle use. }\end{array}$ & 24 & 19 & 21 & 22 & 15 & 26 \\
\hline Add all-day use areas such as picnic areas & 46 & 42 & 38 & 48 & 46 & 45 \\
\hline
\end{tabular}

Attitudes Toward Fees - charging fees for use of public lands can be controversial (Kerr and Manfredo, 1991; McCarville, 1995) and managers of public lands are often concerned about public acceptance of the introduction of new fees. In order to understand the respondent's attitudes toward paying a fee to visit the Colorado Canyons NCA and how monies collected from fees should be spent, we asked four questions. The third question asked consisted of two parts: part A asked the respondent if they would be willing to pay an amount between $\$ 1$ and $\$ 5$ to visit the CCNCA. (This amount was agreed upon in consultation with the BLM management staff as the lower 
and higher amount for fees.) In general, 107 out of 203 respondents (53\%) were pretty open to paying a small fee (between \$1-5) to use NCA (Table 15).

Table 15. Frequency distribution of respondents' willingness toward paying a fee to use Colorado Canyons NCA.

\begin{tabular}{|c|c|c|c|}
\hline Fee amount & $\begin{array}{c}\text { Number of respondents } \\
\text { answering } \\
\text { "Yes" }\end{array}$ & $\begin{array}{c}\text { Number of respondents } \\
\text { answering } \\
\text { "No" }\end{array}$ & No answer \\
\hline$\$ 1$ & 23 & 13 & 0 \\
\hline$\$ 2$ & 24 & 3 & 1 \\
\hline$\$ 3$ & 25 & 20 & 7 \\
\hline$\$ 4$ & 26 & 23 & 3 \\
\hline$\$ 5$ & 10 & 23 & 2 \\
\hline Total $(\mathrm{n}=203)$ & 108 & 82 & 13 \\
\hline
\end{tabular}

Because we were also concerned about public acceptance and the risks of reduced visitation, part B of this question, asked the respondents who indicted that they would not be willing to pay the amount listed to indicate why (Table 16). Of the 82 respondents answering "No" to this question $28(34 \%)$ said that they were opposed to paying for the use and maintenance of public lands.

Table 16. Distribution of respondents answering "no" concerning the payment of \$1- 5 fee to visit the CCNCA.

\begin{tabular}{|l|c|}
\hline I would pay but not this much & $6 \%$ \\
\hline I cannot afford to pay this much & $3 \%$ \\
\hline It is unfair to expect me to pay for better management of these lands & $3 \%$ \\
\hline I am opposed to paying for the use of public lands for recreational purposes & $17 \%$ \\
\hline I am opposed to paying the government for maintenance of these public lands & $17 \%$ \\
\hline I come here now because it is free. & $2 \%$ \\
\hline No answer & $48 \%$ \\
\hline
\end{tabular}

We wanted to know how the respondent felt about fee collection as a future management option for the BLM. These questions were structured for response on 5-point Likert scales of agreement. The responses shown in the table below were collapsed into good idea and bad idea. The respondents were asked, "... iffees were collected at the Colorado Canyons NCA, how should the money be used? (Table 17). Three-quarters of the respondents indicated that they thought that it is a good idea to spend monies collected from fees on wildlife/habitat protection (75\%), dinosaur/fossil protection (73\%), educational materials $(69 \%)$, law enforcement (67\%), toilets and parking $(64 \%)$, and Roads and trails $(61 \%)$. Local residents agreed that monies collected from fees should be spent on wildlife habitat protection (78\%), increased law enforcement (74\%), educational materials (73\%), and more toilets and parking (71\%). However, more than half of the local residents said that it was a bad idea to spend monies on guided tours of the area.

More than one third of the respondent agreed that if recreation use fees were implemented, then they would like for them to be in places where the user can easily recognize and appreciate generally what the fee provides. At the same time, more than three quarters of the respondents said that any recreation use fees should first be used to operate and maintain the facilities from which they are collected and that managers should be given authority to use the balance of collected fees elsewhere in the CCNCA on other recreational priorities. 
Table 17. Distribution of how monies collected from fees should be spent, as a percentage.

\begin{tabular}{|l|c|c|}
\hline & Good idea (\%) & Bad idea (\%) \\
\hline Wildlife/habitat protection & 75 & 6 \\
Dinosaur and fossil protection & 73 & 18 \\
Educational materials & 69 & 20 \\
Law enforcement & 67 & 23 \\
\hline Toilets and parking & 64 & 24 \\
Roads and trails & 61 & 43 \\
Camping areas & 41 & 59 \\
Guided tours of the area & 23 & \\
\hline
\end{tabular}

Options for Types of Fees - we asked seven conditional acceptance-type questions concerning fee permitting options for the CCNCA (Table 18). In general, respondents supported the idea of an annual pass that included the CCNCA and the Colorado National Monument as well as an annual pass that would allow them to visit all BLM locations as often as they would like. There were a few comments that suggested that fees were a good idea for large recreational groups and overnight campers. Many respondents (37\%) wrote "NO FEES" across this section without answering any of the questions. Several respondents offered suggestions for alternatives to charging fees:

"Local Pass" or Pass exchange for say 2 days a year of working with bonafided trail maintained efforts or trash pick up days. For Mack/Loma/ Fruita and Redlands residents this is part of your backyard. 3-5 remote hike-in, only overnight camp spots on a pre-reserved (extra fee to anyone using) basis for full moons, holiday weekend, etc.” (Appendix D).

Table 18. Percentage of respondents that agreed that the following fee permitting options was a "good idea."

\begin{tabular}{|c|c|c|c|c|c|c|}
\hline & $\begin{array}{c}\text { Male } \\
(\%)\end{array}$ & $\begin{array}{c}\text { Female } \\
(\%)\end{array}$ & $\begin{array}{c}\text { Mesa } \\
\text { County } \\
\text { resident } \\
(\%) \\
\end{array}$ & $\begin{array}{l}\text { Non- } \\
\text { resident } \\
(\%)\end{array}$ & $\begin{array}{c}\text { Retired } \\
(\%)\end{array}$ & $\begin{array}{l}\text { Not } \\
\text { retired } \\
(\%)\end{array}$ \\
\hline $\begin{array}{l}\text { Different fees for different lengths of } \\
\text { recreational stays }\end{array}$ & 61 & 67 & 67 & 50 & 63 & 64 \\
\hline $\begin{array}{l}\text { Different fees for resident versus non- } \\
\text { resident }\end{array}$ & 70 & 46 & 30 & 10 & 15 & 29 \\
\hline $\begin{array}{l}\text { An annual pass that includes the } \\
\text { CCNCA and the Colorado National } \\
\text { Monument }\end{array}$ & 68 & 75 & 71 & 62 & 73 & 70 \\
\hline $\begin{array}{l}\text { An entrance fee for high use periods } \\
\text { such as holidays and weekends }\end{array}$ & 41 & 42 & 43 & 40 & 44 & 41 \\
\hline $\begin{array}{l}\text { A fee for specific recreation use, such as } \\
\text { the use of camping sites }\end{array}$ & 65 & 62 & 67 & 60 & 68 & 60 \\
\hline $\begin{array}{l}\text { An annual pass that would allows you to } \\
\text { visit all BLM locations as often as you } \\
\text { would like }\end{array}$ & 66 & 65 & 71 & 52 & 63 & 68 \\
\hline $\begin{array}{l}\text { An annual pass for all of the areas } \\
\text { within the region managed by different } \\
\text { federal agencies (e.g., U.S. Fish and } \\
\text { Wildlife Service, National Park Service, } \\
\text { U.S. Forest Service, and the BLM) }\end{array}$ & 61 & 65 & 66 & 52 & 68 & 60 \\
\hline
\end{tabular}


Half of the local respondents felt that they should not have to pay for something that they have "been using for free" all of their lives." However, many written statements, in response to this question, revealed that the respondents were open to paying a small fee, if the monies from fees were used to improve the NCA and "not go back to Washington, DC." While other's suggested that paying a fee would be "double taxation" or double billing because they are already paying the government once in property and income taxes. BLM should not implement a practice of collecting user fees for casual recreation use. Many respondents reported that the BLM should not collect fees to substitute for tax based funding for the basic management of public lands.

\section{"Stewardship of these lands and resources is the responsibility of all of the citizens and should continue to be funded through the managing agency budget process." (Appendix D)}

It is interesting to note that local and non-local respondents reacted the same way to the possible collection of fees at the CCNCA. Both groups were interested in paying a fee only if the monies were going be used directly for the upkeep and maintenance of the CCNCA. The responses were almost identical concerning the distribution of how monies collected from fees should be spent. Across both groups the respondents felt that protecting the resources was the most important use of funds collected from fees followed closely by increased law enforcement. Although there was some disagreement about guided tour groups, there was an interest in educational awareness and law enforcement information about the area. This could come in the form of updated outreach materials or personal contact with a resource professional. In general people are more accepting of fees when they have paid fees for recreational experiences in the past and if the perceived benefit of paying the costs is linked to services provided. Finally, the dilemma associated with charging for use of public recreational opportunities is the adverse affect of public loyalty to particular places and the managing agency. Those most loyal to public recreation may prefer it primarily because of price, which is typically subsidized and therefore lowered or free (Bogle and others, 1992).

\section{Section 4}

\section{Economic Analysis}

\section{Visitor Trip Spending Results}

Spending associated with recreational and tourism activities generate considerable economic benefits for the local economy. A tourist usually buys a wide range of goods and services while visiting an area. Major expenditure categories include lodging, food, supplies, and gasoline. NCA management activities can impact the numbers and types of visitors. As more visitors come to an area, local businesses will purchase extra labor and supplies to meet the increase in demand for additional services. The income and employment resulting from visitor purchases from local businesses represent the direct effects of visitor spending within the economy. In order to increase supplies to local businesses, input suppliers must also increase their purchases of inputs from other industries. The income and employment resulting from these secondary purchases by input suppliers are the indirect effects of visitor spending within the county. The input supplier's new employees use their incomes to purchase goods and services. The resulting increased economic activity from new employee income is the induced effect of visitor spending. The indirect and induced effects are known as the secondary or multiplier effects of visitor spending. Multipliers capture the size of the secondary effects, usually as a ratio of total effects to direct effects (Stynes, 1998). The sums of the direct and secondary effects describe the total economic impact of visitor spending in the local economy.

Economic impacts are typically measured in terms of number of jobs lost or gained, and the associated result for employment income. Economic input-output models are commonly used to predict the total level of regional economic activity that would result from a change in visitor spending. The IMPLAN modeling software was used to analyze the economic impacts associated with NCA visitor spending. IMPLAN (IMpact Analysis for PLANning) is a computerized database and modeling system that provides a regional input-output analysis of economic activity in terms of 10 industrial groups involving as many as 528 sectors (Olson and Lindall, 1996). 
For the purposes of an economic impact analysis, a region (and its economy) is typically defined as all counties within a 30-60 mile radius of the impact area. Only spending that takes place within this local area is included as stimulating the changes in economic activity. The size of the region influences both the amount of spending captured and the multiplier effects. Most NCA visitor spending takes place in the Grand Junction and Fruita area therefore, Mesa County was assumed to comprise the economic region for this analysis. The IMPLAN Mesa County level data profile for the year 2000 was used in this study. The IMPLAN employment data estimates were comparable to the US Department of Commerce, Bureau of Economic Analysis, Regional Economic Information System data (U.S. Department of Commerce, 2003) at the 1 digit Standard Industrial Code level for the year 2000 .

To analyze the local economic impacts, visitors were split between locals (e.g., residents of Mesa County) and those living outside of the local area (hereafter referred to as non-locals). The reason for this split is two fold. First, Mesa County is the main focus of our impact analysis. It is the impact area. Money flowing into Mesa County from outside is considered new money injected into that economy. Second, if local residents visit the NCA more or less, they will correspondingly change their spending of money elsewhere in the local area, resulting in no net change to the local economy. These are standard assumptions made in most regional economic analyses at the local level.

Table 19 shows the percentage of non-local visitors by area and the corresponding number of non local visitors per year. Annual summer visitation estimates for each visitor area were provided by the BLM. The visitation estimates were calculated from the monthly totals of laser counts of vehicles at Rabbit Valley, Loma, and Kokopelli Loops and from laser counts of individuals at Devils Canyon in 2003. The visitor survey results were used to determine the annual percentage of visitors that are non-local. As shown in Table 19, the majority of summer visitors to all three areas are non-local with Kokopelli Loops having the highest percentage of annual non-local visitors $(86 \%)$.

Table 19. Annual summer visitation and percent of non-local visitors.

\begin{tabular}{|lccc|}
\hline & $\begin{array}{c}\text { Annual visitation } \\
\text { estimates }\end{array}$ & \% of non local visitors & $\begin{array}{c}\text { Annual \# of non local } \\
\text { visitors }\end{array}$ \\
\hline Kokopelli Loops & 35,000 & $86 \%$ & 29,936 \\
Loma Boat Launch & 12,000 & $64 \%$ & 7,663 \\
Rabbit Valley & 20,000 & $58 \%$ & 11,579 \\
\hline
\end{tabular}

Table 20 illustrates the average amount non-local visitors indicated spending locally in Mesa County on their most recent visit. Not every group had expenditures in every category, so the numbers reported in Table 20 represent an average across all visitors, including some who had no expenditure in that category. Besides the categories reported in Table 20, the survey also included expenditure categories related to hunting activities (hunting license, taxidermy, and game processing). However, the visitor survey was distributed during the summer visitor season and no hunting expenditures were reported.

Table 20 shows that on average, non local Kokopelli Loops visitors spent the most per trip (\$85.42) while Loma Boat Launch visitors spent the least per trip (\$35.42). This difference in spending per trip between the visitor areas is due to the average length of trip and the types of expenditures. Loma Boat launch visitors spend on average $51 / 2$ hours per trip, while Kokopelli Loops visitors spend on average 1.1 days and Rabbit Valley visitors spend on average 1.6 days. Even though Rabbit Valley visitors have a longer trip length on average than Kokopelli Loops visitors, average spending per trip is higher for Kokopelli Loops visitors due to spending more on local hotels and restaurants. 
Table 20. Average NCA visitor spending in Mesa County, Colorado.

\begin{tabular}{|l|c|c|c|}
\hline & \multicolumn{3}{|c|}{ \$ per person per trip } \\
\hline Gasoline/related automobile costs & Kokopelli Loops & Loma Boat Launch & $\begin{array}{c}\text { Rabit } \\
\text { Valley }\end{array}$ \\
\cline { 2 - 4 } Hotels & 12.60 & 7.77 & 14.59 \\
Camping & 22.39 & 5.74 & 5.79 \\
Restaurants & 5.22 & 0.85 & 1.55 \\
Grocery stores & 22.54 & 6.71 & 10.57 \\
Supplies \& souvenirs & 9.46 & 9.51 & 8.46 \\
Equipment rental & 7.39 & 1.42 & 10.96 \\
Rental car & 1.36 & 1.21 & 2.62 \\
Other costs & 2.30 & 0.00 & 0.24 \\
Total spending & 2.16 & 2.21 & 2.16 \\
\hline
\end{tabular}

\section{Economic Impacts Associated with Visitor Spending}

The economic impacts associated with spending by NCA visitors are estimated by the following equation:

\section{Number of NCA visitors*average spending* regional multiplier = Economic Impact}

For the purposes of this analysis, NCA annual visitation estimates for each visitor area were provided by the BLM (Table 19). Survey results on visitor spending (Table 20) provide the average spending per visitor day. The IMPLAN modeling system was used to derive the multipliers that capture the secondary (indirect and induced) effects needed to determine the economic impacts of visitor spending.

Visitor spending is typically estimated on an average per day (eight hours) and/or an average per trip basis. For this analysis, visitor spending was calculated on a per trip basis to keep consistent with NCA visitation records. As shown in Table 19, the annual non-local summer visitor trips are estimated at 29,936 for Kokopelli Loops, 7,663 for the Loma Boat Launch site, and 11,579 for Rabbit Valley. Multiplying the annual non-local visitation estimates by the dollar spent per person per trip (Table 20) yields the total annual non-local visitor spending in Mesa County. Table 21 shows the current level of annual spending in Mesa County by non-local visitors for each management site.

Table 21. Total annual spending in Mesa County Colorado by non-local visitors (in millions of dollars).

\begin{tabular}{|c|c|c|c|}
\hline Kokopelli Loops & Loma Boat Launch & Rabbit Valley & Total \\
\hline$\$ 2,557,148$ & $\$ 271,436$ & $\$ 659,305$ & $\$ 3,487,889$ \\
\hline
\end{tabular}

As shown in Table 21, the current level of NCA visitation accounts almost \$3.5 million of spending annually by non-local visitors in Mesa County. Table 22 shows the economic impacts associated with the current level of NCA visitation for Mesa County by visitor area. The table shows the direct impact, the indirect impact (e.g., the multiplier effect), and the summed total impact of income and jobs. 
Table 22. Economic impacts of non-local visitor spending in Mesa County, Colorado.

\begin{tabular}{|lccc|c|}
\hline \multicolumn{1}{|c|}{ Mesa County } & $\begin{array}{c}\text { Kokopelli } \\
\text { Loops }\end{array}$ & $\begin{array}{c}\text { Loma Boat } \\
\text { Launch }\end{array}$ & $\begin{array}{c}\text { Rabbit } \\
\text { Valley }\end{array}$ & Total \\
\hline Direct Effects & & & & \\
Income (\$/year) & $\$ 786,498$ & $\$ 70,973$ & $\$ 171,070$ & $\$ 1,028,541$ \\
Jobs & 46.6 & 3.9 & 9.4 & 59.9 \\
Indirect and Induced Effects & & & & $\$$ \\
Income (\$/year) & $\$ 699,206$ & $\$ 63,721$ & $\$ 152,985$ & $\$ 915,912$ \\
Jobs & 24.0 & 2.1 & 5.1 & 31.2 \\
\hline Total Effects & & & & \\
Income (\$/year) & $\$ 1,485,704$ & $\$ 134,694$ & $\$ 324,055$ & $\$ 1,944,453$ \\
Jobs & 70.6 & 6.0 & 14.5 & 91.1 \\
\hline
\end{tabular}

As shown in Table 22, annual CCNCA non-local visitation accounts for $\$ 1,944,453$ in personal income and 91 jobs in Mesa County. Most of the CCNCA visitor spending personal income and job impacts are in the eating and drinking and the hotel and lodging places industries. In 2000, Mesa County total personal income was estimated at \$2,922,073,000 and total employment was estimated at 71,081 jobs (U.S. Department of Commerce, 2003). Therefore, CCNCA non-local visitor spending represents approximately one-tenth of $1 \%$ of total income and employment in the overall Mesa County economy. Any decrease in visitation associated with a change in CCNCA management will not have a significant economic effect at the County level. An increase in both the length of stay on the CCNCA (and in the local economy) and the number of people visiting the CCNCA could have a considerable impact on increasing the role NCA visitors play in the local economy.

\section{Discussion}

The results from this study represent a snapshot of the challenges that the CCNCA managers and planner face concerning the increasing demands for natural resources. This study, and many others, point out that recreation is at the forefront of those demands. In order to provide a satisfactory or higher level of service, changes in the current management paradigm are seen by some as a necessary part of the future. The controversy of multiple use paradigms has been expressed, both from the perspective of public land managers and the publics that they serve (McCarville 1995). Any anticipated public response to land management strategies is important, therefore, managers equipped with an understanding of the likely response to proposed strategies are better positioned to develop programs that will enhance and expand visitor services, expectations and satisfaction.

There are several messages that managers and land-use planners could take from these results. First, BLM manager should recognize that undeveloped use is important to the overall CCNCA recreational experience. The desire to recreate in an undeveloped area is indicated across multiple measures of visitor satisfaction and experience. Second, although the economic impacts associated with current CCNCA visitation are somewhat limited in terms of the general local economic activity at the County level, the CCNCA plays an important part in the overall recreational opportunities and scenic open space that makes the area a popular tourist destination. Finally, outreach strategies by managers could involve educating the community about activities that will encourage ecosystem stewardship. However, if funds are limited, managers could dedicate resources toward building ecosystem management plans that better reflect an understanding of the people and communities they serve (Johnson and Bowker, 1999). Field (1996) suggested that most managers today require training that involves interdisciplinary development of ecological strategies that enable integration of social, cultural, and biophysical values within the ecosystem management process (Brunson 1993; Decker et al. 1996).

Our findings suggest that the CCNCA could consider a fee demonstration program. We found that in general, visitors would support a minimal user fee. However, this support may come with some opposition from local users who may consider the CCNCA to be an extension of their "backyard." We found that local users reported slightly less support for fees than non-locals. At Devils Canyon where use is predominately local, 60\% of respondents indicated that they would reduce the number of visits or go elsewhere to recreate. If user fees are 
implemented, the BLM should recognize that recreational user support for the fees may be contingent on the following factors: fees are spent at the local level, fees are used to limit resource impacts, and fees are used to maintain current trails and facilities. We also found that support for fees for trail and facility development varies among sites.

To address this, natural resource managers and planners could focus on working toward an easy-tounderstand, consistent, and efficient means of studying visitors. New methods in monitoring and analyzing visitor flows can benefit BLM management in more accurately assessing recreational use over a widely dispersed area.

\section{Conclusion}

Because people are a part of the ecosystem we must continue to integrate human-ecosystem relationships into land management practices; this type of integration will enhance the ability to manage natural resources and minimize conflicts among competing uses of the resource (Cordell and Bergstrom 1999; Galliano and Loeffler, 1999). Natural resource managers and administrators are beginning to recognize the importance of multidisciplinary information on the magnitude and potential effects of disturbances that affect human use of and access to natural resources. Increases in human population, recreational activities, and industrial and residential developments all create divergences in human behavior and resource management. A human-ecosystem or human dimensions perspective can document a variety of viewpoints and by studying the attitudes and perceptions of the general public we can attempt to build a more holistic understanding of the science that informs ecosystems management (Cordel and Bergstrom, 1999).

The results from this study attempted to assist BLM managers in making informed decisions about the development of future management plans and practices that will impact visitor and the residents of the local community. Our research gives an idea about the trends and issues that the management agencies are beginning to face (i.e. overlapping visitor use, rising levels of visitation, and a mismatch between visitor and manager expectations). We feel that by focusing on the environmental values that ultimately contribute to quality of life, research such as this has the potential to assist natural resource managers develop policies that will result in publicly acceptable and politically viable programs.

Finally, conducting research on visitor use patterns involves a close, cooperative working relationship between scientists and natural resource managers. The close working relationship between the BLM NCA managers and the U.S.G.S. scientists was the fundamental component of this research effort. Through the development of this relationship we were able to identify at several areas of additional research that should be considered for the CCNCA:

- What are the national trends in recreational use and management on federally managed lands?

- What are the current and potential visitors' needs, expectations, and motivations for visiting public lands areas?

- What are the demographic shifts that are going to affect recreational behaviors and attitudes in the next 10 to 20 years?

- Do socioeconomic and demographic shifts affect local or regional public preferences for resource use and management

- Are there differences in the way that different culture groups use the CCNCA

- Does the current management strategy reflect the diversity of cultural values in the local community?

- What are the information and educational needs of current and potential visitors of the CCNCA?

Natural resource and outdoor recreation managers, planners, and researchers have been primarily concerned with the effects of how recreationist habits and behaviors alter wildland communities. The majority of existing research has largely focused on recreation use patterns and behaviors of the general population. However, with the expected socio demographic changes natural resource researchers are encouraged to study the recreation use patterns of ethnic and minority groups, older visitors, women, and other nontraditional users. Cooke and Borrie (1995) noted that because visitor attitudes towards recreation use have remained relatively consistent despite socio demographic changes in the U.S., it is time to move beyond the characteristics we have typically monitored (age, income, education, etc) and focus on quality of life and sense of place issues, ethnicity changes in communities, disabled and 
minority uses of natural resource areas. We must begin to consider how diverse groups and people experience and value places such as the CCNCA. Quality of life and sense of place depends not only on how we use or value wilderness when we are there, but how we value it when we are not there.

\section{Literature Cited}

Babbie E. R., 1975, The Practice of Social Research: Belmont, CA. Wadsworth Publishing Company, Inc., 510 p. “The BLM's priorities for recreation and visitor services." BLM Work Plan Fiscal Years 2003-2007, (http://www.id.blm.gov/publications/data/recvisit.pdf) (Retrieved May 5, 2004).

Bogle, T., Havitz, M., and Dimanche, F., 1992, Sector bias in adults' recreation fitness selections: Journal of Park and Recreation Administration. vol. 10, no. 3, p. 49-74.

Brunson, M.W., 1993, Socially acceptable forestry: What does it imply for ecosystem management?: Western Journal of Applied Forestry, vol. 8, no. 4, p. 116-119.

Cooke B., and W. Borrie, 1995, Trends in Recreation Use and Management of Wilderness: International Journal of Wilderness, vol. 1, no. 2, p.

Cordell H.K., and Berstrom, J.C., (eds.), 1999, Integrating Social Sciences with Ecosystem Management: Human Dimensions in Assessment, Policy and Management: Champaign, L: Sagamore Publishing.

Decker, D.J., Brown, T.L., and Knuth, B.A., 1996, Human Dimensions Research: Its importance in natural resource management, in A.W. Ewert (ed.) Natural resource management: The human dimension: Boulder, CO: Westview Press.

Dillman, D.A., 2000, Mail and Internet surveys: The Tailored Design Method (2 ed.): New York, John Wiley and Sons.

Field, D.R., 1996, Social Science: A lesson in legitimacy, power and politics in land management, in A.W. Ewert (ed.) Natural resource management: The human dimension: Boulder, CO, Westview Press.

Galliano, S. J. and Loeffler, G. M., 1999, Place assessment: How people define ecosystems: General Technical Report PNW-GTR462, Portland, OR: U.S. Department of Agriculture, Forest Service, Pacific Northwest Research Station, $31 \mathrm{p}$.

Johnson, C.Y. and Bowker J.M., 1999, On-site wildland activity choices among African Americans and White Americans in the rural south: Implications for management: Journal of Park and Recreation Administration, vol. 17, no. 1, p. 21-39.

Kerr, G.N. and Manfredo, M.J., 1991, An attitudinal based model of pricing for recreational services. Journal of Leisure Research, vol. 23. no. 1, p. 137-50.

Lamb, B.L., and Cline, K, 2003, Public knowledge and perceptions of Black-tailed Prairie Dogs: Human Dimensions of Wildlife, vol. 8, no. 2, p.127-143.

McCarville, R.E., 1995, Pricing for leisure services: An ethical dilemma?: Journal of Applied Recreation Research, vol. 20 no. 2, p. 95-108.

Mitchell, M.Y., Force, J.E., Carroll, M.S., and Mclaughlin, W.J., 1991, Forest places of the heart: Incorporating special places into public management: Journal of Forestry, vol. 914 p. 32-37.

Olson, D. and Lindall, S., 1996, IMPLAN Professional Software, Analysis, and Data Guide: Minnesota IMPLAN Group, Inc,.

Pierce, J.C., Beatty, K., and Hagner, P., 1982, The Dynamics of Americ an Public Opinion: Patterns \& Processes: Glenview, IL, Scott, Foresman \& Company.

Ponds, P.D., 2001, Quality of life on the Colorado Plateau: A report to the respondents in southwestern Colorado and northwestern New Mexico: U.S. Geological Survey Open File Report 01-233, 23p.

Purcell A.T., Lamb, R.J., Mainardi, E., and Falchero, S., 1994, Preference or preferences for landscape?: Journal of Environmental Psychology, vol.14, p. 195-209.

Rasker, R., and Glick, D., 1994, The footloose entrepreneurs: Pioneers of the new west?: Illahee, vol. 10, no. 1, p. $34-43$.

Rea, L. and Parker, R., 1997, Designing and Conducting Survey Research: a Comprehensive Guide: San Francisco, CA, JosseyBass Inc., Publishers.

Stynes, D., 1998, Guidelines for Measuring Visitor Spending: Department of Park Recreation and Tourism Resources: Michigan State University.

Taylor, J.T., Burkardt, N., Caughlan, L., and Lamb, B.L., 2000, Thinking outside the lines: Parks and the quality of life in area communities: Park Science, vol. 20, no. 1, p. 14-17.

Taylor, J.G., Reis-Ruehrwein J.B., Sexton, N.R., and Blahna, D.J., 1999, Quality of life on the Colorado Plateau: A report to camerasurvey collaborators in southeast Utah. Fort Collins, CO: USGS, Midcontinent Ecological Science Center (http://www.mesc.usgs.gov/products/presentations/rep/rep.shtml), (Retrieved April 20, 2004). 
Taylor, J.G., Czarnowski, K.J., Sexton, N.R., and Flick, S., 1995, The importance of water to Rocky Mountain National Park Visitors: An adaptation of visitor employed photography to natural resource management: Journal of Applied Research, vol. 20 no. 1, p. 61-85.

U.S. Department of Commerce, Bureau of Economic Analysis, Regional Economic Information System, 2003, www.bea.gov Warzecha, C, and Lime, D., 2001, Park attachment in Canyonlands National Park: Visitors' assessment of setting attributes on the Colorado and Green Rivers, Journal of Park and Recreation Administration, vol. 19, no.1, p. 59-78. 



\section{Appendix A}

Intercept Survey - Question Summaries 
Appendix A 
Appendix A 
Appendix A 
Appendix A concluded 


\section{Appendix B}

CCNCA Visitor Survey - Respondent Comments 


\section{Loma}

Comment: Fees collected for use of "public lands" should not be allowed, except where someone is using that land to make money I.e. grazing of livestock, commercially guided tours and/river. Once fees are charged, a whole government industry of collection, accounting, law enforcement grows out of them. This "government industry" only grows in size and cost thus fees always rise, they never go down. Also, in this process policing regulation increases and some of the values that brought people here in the first place are lost.

Comment: Please restrict motorized boat travel please do not require permits to float ruby/Horsetheif. We are happy to pay fees and would like camping areas at Loma. Thank you!* River camping on first come first serve instead of signing up.

Comment: High speed motor boat and jet ski activity in Ruby Horsetheif Canyons detracted from our raft/kayak accessed wilderness experience. Would prefer ban on motorized boats or restricting them to wakeless speeds. 2) Would like to see more ranger activities related to educating the river users on leave no trace concepts, particularly in the Black Rock camping areas. 3) currently, I like the permitless access to Ruby Horsetheif canyons, but would be receptive to permit system if in the future river use and associated problems increase.

Comment: The ability to camp at the put-in would be great.

Comment: A ban on gasoline motors would help with water and noise pollution. (Electric motors OK) Developing a trail for all terrain vehicles and motorcycles would SUCK! The thought of it makes me sick. Tell the OHV owners to get off their lazy assess and try hiking or paddling through this amazing country. It's hard to enjoy when you are going $45 \mathrm{mph}$. It would ruin the experience for everyone else on the river, and completely thrash the natural environment. <respondent name

Comment: As a canoe guide for a commercial outfitter my biggest concerns center around convenient access and regulation of river users (proper toilets, removal of trash, etc.) private users have a poor history of compliance. There needs to be a comprehensive "on" river patrol and regulation.

Any fees collected I would spend to that end. Further signage and interpretive material say along Rattlesnake Canyon, Mee Canyon, Black Rock, and McDonald (and Knowles) would be good. I STRONGLY disapprove of motorized traffic in the down river corridor, i.e., ATVS and jet boats.
Comment: Please don't limit the number of boats or people to use this area. There are already too many restrictions for the number of people on the White $\mathrm{H} 2 \mathrm{O}$ areas. It is nice to just go and not have many government rules to follow. The size of the government is already too large!

Comment: If campsites are added. Provide restrooms with showers, like California.

Comment: <answer no to $\$ 4>$ Personally would use no difference I'm sure the USFWS a sister DOI agency would be example.

Comment: <a. answer is does not apply> just camping for boat launches $<b$. answer is very bad idea $>$ there are just going to be more people do something else-fees ok.

Comment: Please come up with fees and camping for this resource it needs financial input badly before it gets ruined more. Its like on one is minding the store and we're getting robbed blind. We need gates and fees at Loma (boat launch, Kokopelli trail) and Rabbit Valley ATV trails and ATV enforcement with ATV's motor less trails and areas. There will just be more use, no one can stop it. Make it self-supporting-it can do it--with nominal fees!!

Comment: I use this launch as part of a contracted guide job with a canoe company only. If there were use fees, I'm not sure if the company would continue to use the launch or not. Maybe such companies could pay an annual fee for unlimited use.

Comment: 1) Prohibit motorized boats from the Loma-Westwater section 2) Develop a 2nd take out/put in at Westwater and designate one for the commercial boaters and one for private boaters. Thank you!

Comment: The fees are just fine of they are not too high. I think people should have the ability to camp at the put in when they are doing a multi day raft trip. When we used the boat ramp, we arrived at 10:30pm. The ranger told us to leave at about 11:30. Too late to find a public camp ground. I also would not like to see the river permitted.

Comment: I've only had this one visit but my experiences with camping and putting in a raft at the boat launch were excellent. It was not too crowded and would be great if the launch could stay the same but with increased use there is always a need to protect the environment.

Comment: Loma boat launch is such an amazing gateway to incredible places. Of course I would love to see its access remain free, but I also understand that funding must come from 
Comment: The number of people, vehicles, amount of noise, etc. at the Loma put-in really detracts from the experience of getting on the water. Full campsites are also a problem.

Comment: In my opinion, the biggest need for the Loma boat ramp is to limit the number of river launches on big weekends (I.e. Memorial Day, Labor Day, July 4, etc.) The only other improvement that would help me is some campsites at the Loma boat ramp.

Comment: Loma boat Launch is a small area with too much going on. It is maxed out at peak times, just with boat launching, rangers did a good job of organizing and facilitating flow on the boat ramp. Do something about the dogs. Too many loose dogs. We to move a couple of droppings piles to be able to rig our boat. Then two loose dogs decided to have a dog fight in the middle of our gear. Suspect dogs harassing wildlife in the canyon is also a problem. Ban--limit or restrict dogs. Look at Desolation Canyon dog policy.

Comment: The BLM range was very informative and helpful. Thank you!!

Comment: During my last visit there were a few fairly large boats with noisy outboard motors racing up and down the river, including through the "Black rocks" area where people were canoeing, kayaking, and swimming. I felt the motorboats were a nuisance and an endangerment to most people on the river. I wish they would not be allowed on the river. That is the only reason I might not return to Loma.

Comment: Have more trashcans available. Outhouse needs to be cleaned more often. Otherwise it's a great place.

Comment: 1) Some seriously drunk bait fishermen congregate here and play loud music at night 2) small but increasing numbers of motorboats and jet skis impact non-motorized use. 3) This is the only overnight river trip in the region which can be done without getting a permit. Please leave us one canyon we can just go visit on the spur of the moment 4) I am a citizen and a taxpayer. I OWN this region. You provide little or no services down in the canyon and I like it that way. Don't charge me a fee to visit MY public lands.

Comment: 1) This is the only no fee, no permit, no application process or restricted number of launches river canyon left. 2) How can you charge a fee for no services and no facilities? Leave it undeveloped, don't charge.
Comment: during summer when water drops on Colorado River, Loma Boat Launch is only place where you can launch aluminum river boat. The only activity at the Loma Launch is the Launching of rafts, canoes, and boats. To ask $\$ 5$ to spend 10 minutes launching a boat is a lot. We would probably try to find an alternative somehow.

Comment: CAMPING!! We love to rig our boats the night before in order to launch early the next morning but we can't rig if we can't camp.

Comment: I don't like the idea of paying to use public lands, however I completely understand that agencies such as BLM, NPS, etc. have been reeling from sever budget cuts over the years, while dealing with rising visitors and conservation concerns. You have my support--keep up the great work!

Comment: There is no right answer to the question of how to develop this area. Please err on the side of developing it too little-not too much.

Comment: I think that keeping the area natural is a good idea. Too many facilities or allowing offroading in the area may cause problems and would also be expensive. A small fee to use the site would be okay, but it should be universal. I greatly enjoyed my experience at Loma! My survey actually got soaked during some rough water in the canoe, so I appreciate another copy <draws smiley face>

Comment: Bush's plan to trash the west is horrible. I hope you as BLM employees who are to protect the land, you will continue to manage the land, for what is best for the land and wildlife and protect it for future generations. Thank you.

Comment: I think the launch should be kept the way it is. Campgrounds would destroy the area by increasing the traffic. Primitive sites are acceptable, but developed ones would detract from the area. Most people I saw were river-bound. We camped 1 night at the launch and found it completely acceptable.

Collection of a small fee should be initiated and used to maintain the area. We met a local rafter who complained about the area getting trashed. We picked up a few extra pieces of garbage that were not our own, but found the area fairly pristine. Organizing a clean up the river weekend annually might help. The USGS employee who gave us these surveys could have checked river runners for appropriate equipment including a firepan and waste disposal system. That's where the river trashing is concentrated.

Comment: A place like Loma cannot be kept secret forever. Sad as it is to say, charging a fee may keep some "riff-raff" energy out. Most of us come to a place like Loma to appreciate the serenity and beauty, 
not to destroy, contaminate, or impose ugly energy on others. We would, naturally, consider any fee (\$315 ) as a fair exchange for a nice and safe experience. I would hope that others could/would too.

$<$ respondent name $>$

Comment: <answer no to \$5> BLM land should be free to the public

Comment: I am a single mom, with an 8 yr old son who enjoys fishing. I work all week so my son and I can do things together on the weekends. Charging more money is ok for some, but why does it always have to come out of the low income families? I pay for a yearly fishing license for myself, my mother and my annual park pass, what's next?

Comment: Continue to have BLM personal to check for goovers, fire pans, etc.-Minimize control - No fees

Comment: BLM, USFS, USGS, etc. etc. Why so many agencies? It would be SO much more efficient if there was ONE agency for all of this. Pass this on, please.

Comment: Don't double tax me! I already pay for this facility. Issuing permits and policing those permits would consume the lion's share of revenue generated. It's not broke--don't fix it.

Comment: No motors on River. No extra large groups. Maximum number of people 25/group.

Comment: I am $101 \%$ opposed to any other fee implementations. I can not see how Corn Lake or any other State Parks have enhanced my recreational opportunity. The staff is rude, slow, and obsessed with "rules". I know they are not BLM. Education and conservation should be the goals of public land use. I would willingly contribute every time to a box which was labeled "voluntary contribution". Thanks.

Comment: You wouldn't have to charge to use the land if you didn't spend your money on mail and printing brochures.

Comment: It's apparent to me that the Loma Boat Launch and camping areas downstream to Westwater are heavily used. I don't think motors on boats is a good idea on this section of the Colorado River.

Comment: I think the FED should issue one pass, for a fee, to access all FEDERAL FACILITIES and LANDS. Golden Age, Golden Eagle, etc. Don't nickel and dime me to poverty with pilot program fees and different fee cards to carry around. (I.e. Yankee Boy Basin and Lower cataract Lake ) as far as discounts for low-income--I pay more than enough in taxes subsidizing others.
Comment: would like restriction on jet skis, motor boats.

Comment: I am opposed to paying additional fees to the government to maintain these public lands. I believe the taxes which are already collected from businesses and individuals should be sufficient to maintain public lands.

Comment: The federal govt. should fund BGLM, Forest Service, National Park Service etc. well enough that they do not have to rely on all these extra fees.

Comment: Send the Yuppies back where they came from. We don't need more restrictions, we need more things that will boost our area like the Domingues Project.

Comment: Quit printing surveys to save trees--don't send any info or surveys or other mailings asking for money--save that money to build other recreational areas for motorboats and wave runners.

Comment: The Loma boat ramp should be for boats to launch, not for rafters, canoes, and kayakers to camp.

Comment: I did not even notice that there were other activities available besides the one we were there for: to launch our rafts and float to West water. However, I truly appreciated the available parking, clean $<$ draws smiley face $>$ bathrooms, excellent space for launching rafts, etc. We would all be willing to pay a SMALL fee to park our car while we raft and even a fee per group to launch our boats. We would NOT be willing to pay for other activities for which we would not be partaking, such as an annual all-inclusive type pass for other areas or other activities. We think some types of activities should remain free, such as hiking/running or picnicking, or sight-seeing/hanging out. More impactful activities should pay the most, such as horses, bikes, off-road vehicles, etc. Please, please, please do NOT go to a lottery-style permit system for river trips as this is one of the few left without it!

Comment: <checked 1 and 2> I can't check these without some idea of how much the fee might be! If fees are high I would visit less often. If fees are low I would continue to use this place, we only come at once/yr.

Comment: answer yes to $\$ 3$ ? But that is the limit

Comment: It is my belief that this survey is intended to determine if a fees should be charged to use the Loma Boat Launch Area -this is my first and only time here--it was O.K.--nothing special (the rafting trip was very nice though) this reminds me of fee 
demo programs that have been put in place around the country--"another form of taxation" as a U.S. citizen--we already own the land--why should we be taxed twice. I say no fees. Leave the area as a natural setting--w/ low impact maintenance. Let the people see nature as it is.

Comment: My family and I have enjoyed this area for years. As time goes on, it continues to be used by more and more people. Finding a way to allow continued enjoyment of the area, while maintaining the "specialness" and protecting the environment is extremely important.

Comment: 1) We understand the budget situation, so our feeling about fees is that we don't mind paying to visit a site or area as long as the resource is protected. 2) We like the solitude of the river and prefer not to see or hear large numbers of motorized vehicles.

Comment: I am against charging fees for use of public lands. Before implementing any such fees I would like to suggest trying a donation box, with wording that highly encourages people to pay what they can and based on their use. Then, provide only the services that you can afford to, based on donations. Start with toilet and trash cans, then maintain parking.

Comment: < didn't answer> only if necessary to launch my boat.

Comment: <answered no to \$4 I would put in at Fruita or on private and use the river anyway.

Comment: I've been to a number of meetings this is a waste of time. You will do what you want anyway. You will cater to rafters etc. more money coming into the valley to businesses. But they do the most amount of damage to the environment, human waste in large amounts of camping etc. also they are much more disruptive to the environment with large numbers on the river. Jet boats are few and usually are just day trips. This survey in the end will be useless but costly to taxpayers etc. most got. Ventures are. But they provide you with jobs paid by people like me. What a joke.

Comment: The local public does not want fees

Comment:<didn't answer, wrote across question $>$ What's to keep people from launching in Fruita or anywhere on the river?

Comment: < no answer, wrote Comments across table $><$ in answer to a. $>$ you have signs up already, materials create debris $<$ b. $>$ There are river tours already $<\mathrm{c}>$ These are in place $<\mathrm{e}$.? You have this already $<$ f. $>$ state park highline Fruita $<$ g. $>$ signage is there $<$ h. $>$ its in law
Comment: <no answers a.-d.> The state park is 4 miles East, that's what Kokopelli is for. <answered e. very bad idea $>$ this creates a huge problem with trash the theory--build it and "they" will come.

Comment: < didn't answer, wrote "No Fees" in large letters across table $>$

Comment: Enlarge parking area, provide picnic and camping areas, coordinate w. Colorado state parks boat launch, no motorized except for BLM and DOW.

Comment: Loma boat launch is fine the way it is-just keep it clean! No motorized vehicles on or off the river.

Comment: I prefer an undeveloped recreational area, however, I also think clean restrooms and trash pick up is important. We only use Loma boat launch as a launch. For the \# of people on the river weekend of June 13th, I thought things were basically good. I don't know if volunteer groups are too difficult to organize, but perhaps volunteers for outdoor Colo. Could run Ruby Canyon and do a trash pick up occasionally. I prefer no motorized vehicles including boats and ski jets!!

Comment: I am opposed to fee program as it creates an incentive for local offices to develop natural areas and draw in more people in order to have more friends for needed projects. Instead the BLM needs to get these funds to protect and maintain our public lands from the federal government.

Comment: This entire questionnaire is bogus, you guys do what you want anyway--all this stuff is just so much pap for covering your squares re. Public input. All these alternatives are fairly disgusting-leave this waterway alone--you control almost everything else.

Comment: The public has maintained the boat ramp and ruby Horsetheif campsites well-clean-we do not need a ranger or more bureaucracy. Please leave alone what is working well as is.

Comment: <responded yes to $\$ 5>$ Because I would have no choice! Put in at Fruita State Park is also \$5.

Comment: How about an Honor System box for overnight camping only. $\$ 2.00$ a head--no more.

Comment: We use the boat launch to launch personally owned rafts. A shaded picnic area would be nice, but how would we unload gear and set up rafts around other picnickers? It would be too crowded. 
Comment: I think access to public lands should be free, but use of services (camping, ATV trails) should require a fee.

Comment: I am against fees for access to public land, but I am willing to pay fees for services. This is an important distinction.

Comment: This questionnaire does not seem targeted for Loma Boat Launch's most used reason for coming--launching on a river trip. I think attention needs to be given to the river section--less on the boat ramp. Example: many boaters are ignoring the sign up system you put in place--nice new sign and all. Troy (BLM) at the Loma Boat Launch suggested that sign up does not guarantee a site--hence, why bother?

Comment: get the damn dogs under control. Dog fights on the boat ramp, dog poop on the ramp, dogs chasing wildlife in the canyon, barking dogs in camp-all out of control and detracts from experience. By the way, I have big retrievers--issue is too many and inappropriate behaviors. Ran into 3 BLM staff-all very positive and helpful. Fees are OK but should be used to provide a high quality experience--not amenities. Loma boat ramp is a portal from a nearly (or soon to be) urban area to a more primitive zone. Don't overdevelop this site. Consider placing limits on number of overnight river trips--people are pioneering new sites.

Comment: The Loma Boat Launch turned out to be a bad experience for our group on 7/3/03. We unloaded all of our boating gear for 8 people, cooked dinner, and were promptly removed rather unceremoniously by the ranger who told us we couldn't camp anywhere in the vicinity. So, at 11:30 at night, our group had to disperse to Rabbit valley. Rangers the next morning seemed to have no problem with people staying with their gear at the launch. Comment: 1) Get rid of motor boats 2) Charge Extreme $\$ \$ \$$ if motors must be allowed $\$ 40 /$ day and $\$ 2$ for non-motor visitor 3) facility is fine now. <included name and address>

Comment: I am willing to be involved in planning or volunteer stewardship projects. <includes name, email, and phone

Comment: No jet skis or motorized boats carrying rafts should be on the rivers with the kayaks, canoes and rafts, unless they were with the park ranger services.

Comment: Non-motorized vehicles only this would the environmental and habitat no jet skis

Comment: Fees collected for use of "public Lands" should not be allowed, except where someone is using that land to make money I.e. grazing of livestock, commercially guided tours land/river. Once fees are charged, a whole government industry of collection, accounting, law enforcement grows out of them. This "government industry" only grows in size and cost thus fees always rise they never go down. Also in this process policing, regulation increases and some of the values that brought people here in the first

\section{Kokopelli Loops}

Comment: I like what you've done so far to enhance the area. More camp ground with facilities would be fantastic.

Comment: <answered yes to $\$ 3$ fee> this would probably cut down on my frequency of visits.

Comment: I have a problem paying additional money for public lands when taxes, that I pay, already go toward public lands. I am also against the BLM closing public lands to mountain biking, for wildlife and habitat reasons, when horses do just as much damage if not more to trails. My fear, also, is that once fees are put toward Kokopelli trail it will become more commercialized bringing more and more people to that area.

Comment: <answered does not apply to c.> what's there is plenty <answered good/bad idea to wildlife and dino protection and good idea to rock art protection $>$ there's a tendency to get too carried away with preservation.

Comment: <crossed out law enforcement and wrote in rescue groups and answered good idea>

Comment: <answered yes to $\$ 5>$ paying stinks, but we must protect the environment first!

Comment: <answered good idea> Away from nonmotorized vehicles

Comment: Perhaps have foot and/or bike camping on Koko trail (w/o car access). Should separate motorized (ATV, motorcycle, car) and non-motorized (bike, hike, horse) areas..

Comment: A great experience. I support keeping the area natural and free from development, including for motorized travel. An exception is development that works to limit impact in areas that are already heavily traveled. Fees are reasonable but it'd be best to have an easy method of payment (i.e. week-long or yearlong pass rather than having to carry cash on the trail).

Comment: <answered yes to $\$ 5>$ If we arrived and heard there was a fee, we'd be more likely to pay, but 
if we knew prior to arriving, we'd probably go elsewhere. Don't our taxes pay for this stuff?

Comment: Keep the trails as they are. Do not make them any easier or less technical. If you charge a fee, let the public campground (state park) fee be inclusive of the Kokopelli area. Keep things the way they are now. I have not gone to Moab due to the changes that happened there! Thanks for asking for input! <respondents name>

Comment: I avoid fee areas, as do most people I know. We are tired of paying to use our land that we pay for already. Instead of spending 89 billion on Iraq, why not spend 1 Billion on Parks and get them the maintenance they need? All you are doing is keeping the poor out, which we all know is pathetic!! The parks were created for the poor--and everyone else.

Comment: The Kokopelli trail system is one of my favorites in the state because of the scenery, the variety of trails, the location, and the limited number of riders I see on the trails. I wouldn't mind paying a daily fee, but unfortunately, a lot of the revenue goes towards enforcement and that defeats the purpose. Fee's that fund maps are good as well as trail expansion. An idea for additional services would be more trash cans in the parking lot and maybe drill and well with a hand pump for a potable water source.

Comment: What happened to the Ruby canyon management plan that took 5 years and many hours of input to happen? I think BLM is trying to justify their jobs with more paper work. Mesa Co. takes care of the roads and service clubs take care of the trash pick-up and the trail maintenance and the signage was paid with contributed $\$$ from community and town they Valley $\$$ maps are printed with donated \$ What's the problem with maintenance?

Comment: <answered No to a fee of $\$ 5>$ It will cost more to collect and police this then it's worth!

Comment: <didn't answer any questions, wrote "No Fees" in large letters across the table $>$

Comment: Thank you for the free trails I consider myself very lucky to have them. If fees are needed to maintain these areas this is understandable.

Comment: <answered very good idea $>$ an easy/moderate single track between Loma and Moab along the $\mathrm{N}$ side of the hills. To provide loop opportunity other than boring road or strenuous Moore Fun/Mock Ridge routes.

Comment: <answered yes to a $\$ 4$ fee> free recreation opportunities seem to be disappearing.
Comment $<$ didn't answer $>$ not in favor of fees on public lands

Comment: Great trail, will become more and more crowded. Need more trails in the area to compete with Moab. Fees are a bad idea use tax money or lottery money. Develop campgrounds and after riding entertainment. Breakfast locations etc. This is as much about Fruita as it is about BLM land.

Comment: I think Slickrock in Moab has come up with a very successful fee area. The fees don't seem to have reduced the usage and they are able to afford the maintenance for trails, campsites, etc..

Comment: Please do not open any of the Kokopelli or Bookcliffs area to motorcycles or ATVs. It would destroy the trail system that has been built. Right now you have a world class mtn. Biking experience that people travel from all over the world to experience. If opened to motorcycles you would lose that. It would be nice to have some public restrooms built at the end of $18 \mathrm{road}$.

Comment: Improved signage indicating recommended direction of travel on loops would be a good idea.

Comment: < didn't answer any questions, wrote "Don't Collect Fees!" in large letters over the table>

Comment: One of the biggest reasons for moving back to GJ was to hike. As I said before, GJ is a very expensive place to live. I more than understand the need for funding. Perhaps passes like on \#19g. Would work, but it can't bee too expensive like the state park is. Perhaps a semi-annual pass would be an option. I remember when state parks were free. I LOVE this area. Don't make it impossible to enjoy it. Families can't afford vacations as it is.

Comment: Great Mountain biking management should be directed at the maintenance and keeping people on the trails. Fees would be ok, but would seem to discourage use of public lands. Too much management would ruin experience. Trash and toilets are important. Parking seems adequate. Additional camping areas with toilets would be useful. People that are uneducated about desert are trashing the place.

Comment: <didn't answer a. $>$ need more info. $<$ didn't answer c. $>4$ people who stay on trails, it shouldn't be an issue.

Comment: $<$ answered good idea and specified nonres as "of county and Colorado, reinforce locals"> 
Comment < answered good idea to c.> If you want to increase the number of people using trails < answered good idea to e. $>$ if this is a crime problem.

Comment: This was a top 10 weekend for me. I will definitely be back to experience the Kokopelli Trail system!

Comment: <answered yes for fee of \$5> all depends on what $\$$ would be spent for and how much pass would cost. I love to travel and to see new things but if I had to pay for every entry into every experience, I would have to limit my experiences!

Comment: The Kokopelli trailhead needs trash services.

Comment: Kokopelli too primitive, dry, and small to allow camping. Adequate sites at Fruita State Park, $\mathrm{RV}$, motels for pay sites etc. NEARBY. So many hikers and bicyclists so ask motorized use to drive farther out elsewhere. Separate motorized from nonmotorized use, please. \$1-2/day for bicyclists OK for trail/loop maintenance, bathrooms, parking lot. Keep camping out of Book Cliffs, keep motorized use also

Comment: The dirt road that goes down to the river from the troy built junction is not on the big map on Mary's Loop. That threw us off and we paid an unscheduled visit to the river. It will be a good idea to show this road on all maps.

Comment: Please don't charge fees. We pay taxes and it is our right to recreate on public lands! We shouldn't have to pay more! We just want a soft trail to run on.

Comment: Great Area. Don't Spoil it.

Comment: <answered very bad idea> seems most people are bikers, not hikers

Comment: Don't know. You didn't ask if we though a fee was a good idea at all??

Comment: I usually support fees as I am an avid supporter of protecting our resources. I understand that many users of a particular area will negatively impact the environment. However, it seems that everywhere that there are more users, a fee is initiated. I think that there are certainly places where we should leave well enough alone. The vast majority who use that area are mountain bikers--we don't need historical markers, fancy bathrooms, etc. Organize volunteer trail days for maintenance. Keep it lean and mean! <draws smiley

Comment: answered Bad idea to c.> just do signage $<$ answered bad idea to $\mathrm{d}$. $>$ seems there are a lot already Rabbit valley, etc.
Comment: This is some beautiful terrain for mtn biking. Please do not ruin the experience by opening it up to motorized use.

Comment: I'd recommend that you consider the cost of using the area (user's fee) in the context of the total expenses for the trip. In my case, I drove about 300 miles, round trip, to ride here, and I know that a lot of people from Vail do the same. At \$2-3 user fee doesn't amount to much when taken as a part of the total cost of the trip. But don't make it too much..

Comment: It seems that the area just North of the ridgeline and parallels the highway would be a great place for a campground as it is away from the sensitive / unique /aesthetic areas on the river side. I'm sure it would be well utilized as Highline fills quickly and is expensive.

Comment: Don't make people pay for public lands. Don's close trails to mountain bikers. Rednecks with motor vehicles do much more damage than anybody. I have witnessed this. Open Pollacks Bench to mountain bikers. Closing this trail is B.S. ! I also hike and some of those people are assholes. They think the whole world should just hike and nothing else. The BLM should make the right decision. Spend time on the trail and do some research. Find out who needs education on the environment and warn them with signs at trailheads this is a great area, don't make long-term decisions without good

Comment: I have many, many, many, years riding Fruita / G.J. you guys are right on it! Thanx! Way to go G.J. BLM! Yeah baby! Who loves ya baby! You ROCK! Way to go! Fees: yes please! A "suggested" fee--no enforcement required. We will pay. PLEASE BRING BACK PRIMITIVE CAMPING to the frontage road areas @CCNCA. It can work. P.S. Proactive is the only way! Thank you for 18 road. Truly one of the great experiences in the "free" world is camping on 18 road and riding from camp. Thank you so much--seriously!!

Comment: Charge us!! Bikers will pay !! < draws smiley face>

Comment: If you do charge people, locals or trail maintenance volunteers should not be charged. I can understand why you want to charge people. However, since your community does so much for the area, it should be free. Though I'd still visit. I might decide to skip Fruita sometimes on my way through. I can find free trails on the front range that are still great.

Comment: Please do not allow motorized vehicles on any of the existing established mountain bike trails in the Fruita area. 
Comment: I give all my money for this to Congress, it is not my fault they abuse and misuse it! <answer to e. is good idea $>\$ 5<$ answer to $\mathrm{f}$. is very bad idea $>$ they are free now! <answer to 20 is yes $>$ but would not pay fee

Comment: <answered very bad idea> already offered privately commercial

Comment: Great Job. Keep up the good work !! $<$ draws a smiley face $>$

Comment: This is an incredible area. The trails are fabulous and well designed/maintained. I love to escape the Front Range when the weather's bad and visit here. I like the rough, unfinished nature of the area. I wouldn't like to see it become too developed with giant restrooms and elaborate parking. But of course, it's easy to say that NOW. As recreation visitors increase, they must be managed. I also don't want to see recreation restricted from where it is now. The area has been developed with recreation in mind, so I think the current trails should remain open. I can understand if no further trails are built to limit any further disruption to native animals and plants, and I support that. But I'm getting very weary of trails being closed to maintain bikes under the misguided idea that they are more destructive than hikers or horses. At least every ride I go on, I see hikers wandering off the trail, which to me seems much more impactful than mountain bikers, who at least stay on the trail--thanks for maintaining a wonderful place! P.S. If you organize trail maintenance days and contact (gives mtn. biking org name and phone number)

Comment: All of the ideas seem reasonable, I expect recreation to require maintenance, and therefore cost money to users.

Comment: We need to think of new ways to keep single track single w/out closing trails (i.e., Pollack bench)

Comment: A group of 3-4 of us run Mary's Loop / Rustlers Loop / Horsetheif Loop on a regular basis from November to June (about / time / week) I would not object to a fee but here are a couple of suggestions 1) use a pass for frequent visitors similar to the Colo. Nat'1 Monument \$10-15 for a seasonal pass is reasonable 2) Don't charge for the off season in the late fall-winter-early spring no one is out there anyway !!

Comment: <didn't answer> Depends on how it developed. No paved trails--No more 4-wheel drive roads --picnic areas -- yes
Comment: Most Impacts I see are from: 1) vehicles motorized (ATV's, Jeeps) 2) Grazing/Invasive Species Range Impacts 3) Horses. Please limit these impacts to along Frontage Road--N side of Ridge Area. IE--close Colorado River consider to Valuables and Livestock.

Comment: I have been riding the trail for 8 years, usually from Moab to Loma over several days with a group of high school students. We do this to experie3nce physical activity in a primitive setting. I would not like to see development that would alter this experience but I also don't want to see the area ruined do to overuse. Try to keep this in balance.

Comment: A small user fee would be well accepted if amenities are provided; namely, trash cans, pit toilets, potable water, picnic tables, shelters, etc. Most trails are now constructed w/volunteers and maintained. So fees should not be collected solely for trail use; rather, volunteerism should be fostered. The less amenities, the less the fee should be, but it should apply equally to all visitors (local, out of state, elderly, handicapped) and be changed at all times.

Comment: I would like fees to be applied towards making the Kokopelli trail safe for bicycle trekking along the length of the trail most importantly, campgrounds with water supplies.

Comment: This is such a difficult issue. I understand that shrinking budgets and increased usage forces change and/or further evaluation. I just don't know what the best answer is. I lived in Oregon for a while and the fee structure was \$3 / visit and I think \$25 for an annual pass. That seemed reasonable as it covered all state fee areas. However, there was a tremendous amount of controversy about this. I would welcome the opportunity to hear the various ideas people have. I am a regular user of BLM lands and am aware of multi-use issues, trail maintenance, over-use, etc. Hoe that helps..

Comment: $<$ b. answered undecided $><$ on $\mathrm{c}$. answered bad Idea that national monument already included in NM. Parks Pass><answered to d. as undecided.>

Comment: < didn't answer to $\$ 5$ fee and provided own answer $>$ Seems HIGH considering a user who comes for 3 days --that's 15 bucks!!

Comment: <answered good idea> separate from biking trails.

Comment: fees all the time <answered bad idea>

Comment: What does "undeveloped" use mean?<didn't answer> 
Comment: I really enjoyed visiting and riding on the Kokopelli Trails. A \$ charge per vehicle is reasonable. A small fee would not deter most people from visiting CCNCA.

Comment: < answered all as very bad idea $>$ FeeFree!!

Comment: <answered now to a $\$ 5$ fee> Don't make me (us) into a outlaw!!

Comment: A lot of departments would (in the BLM) divide the funds up. The trails would a small percentage of the funding. I've been mountain bike riding for 21 years in Summit County and above 9,000 thousand I've been involved with several organizations and volunteer duties. To rebuild and cut trails. Why can't we do that here with our trails, I would volunteer. But to pay and use, that's not what our forefathers intended. I am very anti-pay and use lets keep out resources free of fees. Thank you $<$ respondent's name $>$.

Comment: Signage was excellent. Rope barriers to keep vehicles off fragile area was good. Add more signs reminding people to stay on trail. Use volunteers. Keep motorcycles separate from horses separate from biking.

Comment: The rustic beauty of these trails makes me travel more than 1,500 miles as often as I can to enjoy them. Keeping the trails open and in good shape for all non-motorized users is important to me. Adding motorized users to these trails would increase the environmental impact to the point where animals and plants will be impacted. Trail fees are fine with me but there needs to be an allowance for very reasonable passes for local trail users. I like the "adopt a trail" system used at the18th Rd. (Book Cliffs) Area. Thank you for taking interest in maintaining and improving these trails. I like the new toilets and the shade canopy.

Comment: <answered very bad idea to b.> Let that be Private <Answered Bad Idea to d.> Use volunteers.

Comment: <answered very important> Escape not a slow activity.

Comment: <Answered No $>\$ 2$ or less is fair Why not ask for donations?

Comment: Some question were vague and ambiguous. This area needs more trails, loops and connections for each user group. Many of these should be segregated by user group and difficulty level indicated. Directional travel on some trails should also be employed. A hiking route to the river could be established also, where people could Park a bike on the Rim and cool off in the river. Smart management, partnering and alternative funding should help the BLM avoid charging fees other than camping. Thanks for Asking.

Comment: I think if you have to charge a fee to maintain the integrity of the land then that would be okay, but a very minimal fee. I.E. $\$ 2$ day use fee on weekends. I am opposed to charging fees to build more man made features and make the area less primitive.

Comment: Money should NOT be collected at all!! $<$ and in answer to very good idea on law enforcement, specified that enforcement be "environmental">

Comment: < didn't answer> I bicycle and hike only and don't think I should be charged for exercise. I pay tones of money in taxes!! I would be angry.

Comment: <answered yes> I rode there ON my bicycle

Comment: No new fees for public lands!!

Comment: This was my 1st time visiting the trail system at Fruita. Our group is made of avid mountain bikers and we normally head straight to Moab but decided to stop at Fruita for an afternoon of riding. It was a pleasant experience. We especially enjoyed the "More Fun" Trail.

Comment: This was a very nice place to visit and ride. Extreme views on either side of an issue make the most noise, yet represent the fewest. Manage this facility for the general public that paid for this land. Not the extreme conservationist nor those who would exploit the natural beauty for profit.

Comment: Like most surveys this one to is a con job and contrives in such a manner to make people feel like paying is a small past of these weekend. It would be very profitable for you to charge $\$ 5$. I do not believe in user fees!!! If you must charge, and I'm sure you will I think \$1 per vehicle would cover the cost of an outhouse!! And a cheap seasonal pass for locals. We don't need more signs, paved parking, law enforcement and all the bullshit national parks have. It is a great place. Just the way it is!! Volunteers built these trails with support from the BLM. Don't ruin it!! The people you are surveying on the weekend are weekend warriors. Save the Kokopelli and take your biased survey away. I will never pay to ride my mountain bike!!

Comment: No Motorized Vehicles. Keep trails open to hikers, mtn. Bikes, horses. There is plenty of space elsewhere for motors. Fees for the BLM as a whole make sense, but no more than $\$ 25$ annually or \$5 / 
visit. Is it possible to do a pass for BLM Forest SVC, and national parks?

Comment: I feel uncomfortable commenting on whether or not fees should be collected at these sites. However, as a former frequent user of Alabama State Parks, I am comfortable paying a \$2 or \$3 dollar daily use fee; provided the proceeds are used to maintain current facilities and not expand

Comment: With regard to road and trail maintenance, I think it should be limited to ensuring that they are safe--that ledges haven't eroded back so that the trail is gone, or no dangerous holes have formed. Keep facilities to a minimum--bathrooms and parking at the trailhead. The more facilitates and recreation options constructed the less natural the environment

Comment: I understand the need for management of public lands, I also understand the financial burden. Over management diminishes the overall experience. Campsites with one or two restrooms are enough. No need to go in and set up tables and maintained roads. The becomes harder to reclamate and or relocate. Other avenues to help maintain trails. In which you have used extensively as well as local mtn bike club. Get other user groups to help, runners, rafters, hikers, equestrians to help individual areas in need. Local business in also willing to help! Then apply for grant and state lottery funds. If every area takes pride in there own they will happily share with others work.

Comment: Fees are a bad idea! <answered bad idea to a.> Waste-use internet/bike shops <answered d. 3, Bad Idea> Volunteers!<answered Bad Idea to e.> For What? <answered Very Bad Idea to f. > Next to I-70? $<$ Didn't answer the rest. $>$

Comment: <didn't answer any demographic questions $>$ How much did this survey cost? What existing problem could be alleviated using funds?

Comment: <didn't answer a. developing more rec exp opp at Koko > too vague--like what? < didn't answer $17 \mathrm{~b}$. Not developing facilities $>$ Too many people are coming for there to be no facilities. <didn't answer 17 c. Adding day-use $>$ Toilets only--Let it be !!

Comment: I hope the BLM does not go the way of the forest service and park system. Super regulation does not necessarily guarantee a better outcome... and it is expensive. Users need to solve problems on their land with your assistance and resources. The govt's job is to lead the people toward a better existence. Many areas of Business are learning to collaborate to facilitate working to save money and increase ownership of ideas and resources. Recreation (Public) should be developed only the amount. That it does not degrade the land and experience beyond natural human scarring.

Comment: I would like to see motorized ATV/motorcycles use prohibited in the chutes and ladders area of Fruita. They destroy single track. Mountain Bikers have very few areas of fantastic single track like that in Fruita and it would be terrible to lose it.

Comment: I thought that BLM land was national if so.. $<$ Answered 4 , very bad idea $>$

Comment: Development and promotion of an area only bring more people, which requires more development and more promotion to justify the development and it just goes on. I realize that the situation is difficult. However, I also think that BLM land should be left more primitive. Let the NPS create the Disney World's. Let local recreation group maintain the trails and leave BLM money for something else. Of course, local groups will want to promote the trails and there you have it. Good luck, you'll need it.

Comment: $\mathrm{t}$ is becoming less natural but still very impressive

Comment: minimal <didn't answer>

Comment: This is a beautiful biking trail. I have been visiting here for over 5 years. I used to drive from Vail and had friends from Denver come as well. Great mountain biking for EVERY level, that is the appeal of this trail. $95 \%$ of the people I see are mountain bikers. Charging money to ride a trail would be a first for most people that visit and I personally would choose to ride other trails that my current tax $\$$ support. Thanks.

Comment: $<$ did not answer any of the questions under question 18. Wrote "NO FEES" across the table>

Comment: This survey asked how much I spent on this one visit. Past visits have included more expenditures, such as dining, purchase of guide books, patronization of local bike shop, etc. Also, while a $\$ 4$ fee is reasonable, I am opposed to paying high rates--\$10 / day --to the Gov't to use public lands unless that fee includes services like a national park, for instance.

Comment: I'm quite concerned about fee usage in public lands. Low income people should never be restricted from using public lands. Hopefully alternative funding methods can be found.

Comment: You must be making a lot of money doing this survey. Paying for using public lands is a BAD idea!!! I will never pay to ride my bike, hike etc.!!! 
Like most surveys this one is contrived so that no matter what, you will be charging to ride Kokopelli. Well I hope you choke on the \$\$. Hayduke lives!! $<$ circled the Paperwork Reduction words at the bottom of the page and put exclamation marks $>$

Comment: <answer yes> Unless you start charging

Comment: <answer 6 does not apply> keep it that way

Comment: This was my first recreational trip to Colorado. I was completely impressed and in awe with the beauty of the land. The people were so helpful and friendly. I really enjoyed the slower pace. The Kokopelli trail was great fun. Technical but not too technical. Better than Moab!

Comment: <Answer Yes> \$15 would be my limit.

Comment: Beautiful area, great biking trails. I will be visiting again in the future. The day that I visited, they were giving away a map of the Kokopelli Trail area. I didn't get one, could you please mail me a map? < respondent name and address $>$ Thanks, $<$ respondent name $>$.

Comment: I just think u guys $r$ awesome! Thank You!

Comment: I only use the Mary's Steve Horse Thieves area. I have no trouble paying a usage fee providing it was available as a seasons pass.

Comment: It's great the way it is now. Fees could provoke more careless use of the land by visitors. People will thank since they paid to enter, they can trash it and someone else will pick it up. Public use land should be "free" -> taxes.

Comment: I believe better management of the existing tax money is in order here. If trail damage is the main concern, limit off-road vehicles such as jeeps, 4-wheelers and other motorcycles as they mostly destroy trails. I know for a fact most mountain bikers will not continue to come here if fees are required. I for one will certainly not.

Comment: Change a fee for mtn bike usage during peak seasonal times. If picnic or campsites are developed, charge for these activities year around. Add another mtn. Bike parking area west of Loma Boat Launch area 3-5 miles.

Comment: The location of the Kokopelli to I-70 and the rocky terrain make it a local favorite. To publicize it more would be good for the BLM in the short run but have a devastating affect in the future. Its location makes it too accessible and to make it easier for motorized use would create conflict between Mountain Bikers and Motorists to develop areas is a good idea but some things should be left alone.

Comment: I, like many, many people, would very much like to see OHV use decreased in areas like the Kokopelli Trail. It is so harmful on the environment and is so annoying!! It can't be good for wildlife, wildlife habitat, and the natural beauty of the area, which is the main reason people hike/mountain bike in

Comment: Motorcycle/OHV riding and Hunting should be eliminated!!

Comment: Free during weekdays?

Comment: I don't think we should pay to camp on BLM. I will gladly pay to ride b/c of the impact on the land. This was my 1 st $\mathrm{mtn}$ bike experience and Kokopelli was the PERFECT place. Thanks for giving your time to this cause.

Comment: Rustic and undeveloped is good and becoming a rarity. I am concerned about the idea of adding a fee for use as it would limit equal access. I am more willing to live without the extras than add a fee.

Comment: I do not want to be charged a fee but..

Comment: I do not want fee; but if...

Comment: <Answer was NO> I say this because undeveloped is best and access should be fore all; not just those who can pay.

Comment: Good Idea if the rec exp opp are developed for kayak river activities and hiking

Comment: Keep Kokopelli wild. Provide only trash pickup and bathroom facilities. If necessary charge a minimal fee for camping. If you need to raise $\$$ maybe sell $\mathrm{H} 20$ at the trailhead.

Comment: <Answer does not apply> \#17dmanagement of, or management for motorized use??? There are many areas of BLM open to motorized off Road (ATV, Jeep, Motorcycle) abuse already. You need to manage this area to save some non-motorized trails to quiet clean users!

Comment: this was our 4th year out here for a weekend of biking. The number of people using the trails seems bigger every year. Unfortunately, not all users have the same level of respect for the area. Levels of trail etiquette vary as well. I think a bit more trail management (signs for areas that need protection, one-way arrows on parts of some trails) may be helpful

Comment: I am completely in favor of a fee system. As long as the money stays at the area it was 
collected. I believe environmental impact should be the primary consideration when developing a usage plan for this area. For example, Hikers have very little environmental impact, so the largest area should be available to them. On the other hand, motorized vehicles have a very large impact on the environment, so their allotted areas should be small and

Comment: Nice job on the trail system. I would like to see a similarly developed motorized trail system on the North side of I-70. Preferably with lots of single track motorcycling opportunities.

Comment: Fruita has the potential to be a great mountain biking Mecca, but unless more trails are opened and the elitist attitude of the locals is tempered, I doubt this will happen. (of course, the aforementioned locals will be glad).

Comment: <Answer Bad Idea to No fees charged on weekdays $>$ Those on a limited income probably have a decreased opportunity to recreate on WEEKDAYS.

Comment: Please preserve this incredible resource by minimally development. Please do not develop off-road trails for ATV--they are extremely destructive! Send them to the desert--with no populated areas near. Thank you, $<$ name of

Comment: <Answer to Toilets and parking, Good Idea $>$ Already Exists Minimal

Comment: No fees!

Comment: No fees please!

Comment: More single track! Go across the river.

Comment: I think the terrain is very fragile and needs protecting. After the third day of the Fruita Fat Tire I thought the terrain had deteriorated on some of the trails. I loved being able to ride them but worry about the terrain being able to withstand extended high volume use.

Comment: Great trails in the area! My 2nd fat tire festival in a row.

Comment: If fees become necessary, it's important that they be used locally for maintenance and educational activities at the site they were collected. I would much rather see the environment and recreational activities given a higher priority in the national budget. Perhaps we could forgo invading some small, oil-rich country for a year or two to help fund these

\section{Devil's Canyon}

Comment: I'm very wary of effects to get more people to visit the trail. As overuse will detract from the experience and damage the trails. Also please, please, please keep motorized vehicles off the trail.

Comment: Terminate to Fee Demonstration Project. Petition Congress to Fund the USFS, BLM, NPS, and others at their full level so they do not rely on fees. I avoid "Fee Demo" areas and seek free public land recreation.

Comment: No Fees at all

Comment: this was a beautiful area--lots to see on mountain bikes. We could easily have ridden several days to see everything. We especially enjoyed it because the area is open, free, non-restrictive, varied terrain, friendly and not crowded-not commercialized. We'd love to see it remain as it is. However, I am sure that camping areas would be appreciated by many (but with that would cause more roads!)

Comment: <Answer was 2, I would visit this location less often in the future $>$ and use other biking trails in the area. $\$ 3.00 \times 5$ people $=\$ 15.00 /$ day for use. It all adds up.

Comment: NO FEES PLEASE!! Keep public lands open and free, this is why I chose Devils Canyon instead of Co. Nat Monument I appreciate what you've done with the area, especially closure to motor vehicles and ATV's It's great just the way it is, don't need another national park type experience.

Comment: I am getting sick and tired of government agencies trying to find new ways to tax me. I'm already paying sales taxes, state income tax, federal income, user taxes galore, etc. , etc. If the BLM is having difficulties staying afloat maybe they do like the civilian sector and start trimming the useless fat from within. The BLM keeps converting our best local usage areas into high-overhead, fee-based areas that require additional funding simply to advertise to other heavily populated areas (I.e. the Front Range and SLC areas). The end result is that I will eventually have to travel hundreds of miles to go on a trail run rather than be able to go out into our local PUBLIC lands. Oh yeah, I'll be happy to pick-up my dog's excrement when the BLM requires horse owners to do the same. At least my dog doesn't shit all over 'th f'n trail'. I don't give a damn if horse shit is cleaner or not, I'm tired of the preference demonstrated toward horse owners.

Comment: The purpose of our trip to Fruita and Moab was to mountain bike. It was disappointing to 
find access basically closed in the Devils Canyon. A person doing a survey informed me it was due to wildlife preservation, which I respect, but at the same time these trails are open to hikers and horses, which will effect wildlife as much as bicycle access. This makes me think the real reason is conflicting uses coupled with a closed mindset. I strongly support reopening these trails to bicycle access.

Comment: I feel it is important to preserve the beautiful environment that we have at Devils Canyon. It would be a mistake to open this area to motorized vehicles / ATVs and/or camping.

Comment: Hi Shana, I love those canyons so much. I started going there 15 yrs. Ago. No trails except the sheep trails. Got permission from the back. I would simple die if it wasn't there. . I saw the jeeps and all terrain vehicles tear it up so badly for years. So SAD! I think it is developed enough. The poor fish and frogs in the ponds what happened with that? Also, 200 house all being built. What effect will that bring. My partner for 9 yrs and I are so concerned with the future of these great lands. When you build a parking lot for horse trailers--you need input from people with the big rigs--we use to park on the top of the hill and ride down into the road--not where the lot is now on top over looking the river anyway. The lot they put in there--on top--we can't park there too small / my trailer is $22 \mathrm{ft}$. 4-door truck. Is there some way to stop the 200 houses? I do care about these beautiful canyons. "Flume" is my favorite. So the rocks slide down wall one day. What a experience. I've walked and ridden every part from Kings view to "mee"-wow isn't "mee" something!! Thanks <respondent name and telephone number>

Comment: I like that Devil's canyon is off limits to motorized vehicles. It is one of the few places you can ride horses and not have a motorcycle or ATV drive up next to you while you are enjoying the views and the wildlife. IT has a peaceful environment for the riders, horses, wildlife and hikers.

Comment: Maps of trails, or approx. time to hike trails would have made our hike perfect!

Comment: Trail maps or approx. hiking time would be helpful

Comment: A very wonderful and beautiful area! Trails could be better marked (we got a little confused) camping would be awesome! One of my favorite areas!

Comment: This is the first time I heard about the plan to charging a fee for Devils Canyon Area and it saddens me to think that there are people out there who seem to think that this area needs to be developed further. I'm sorry to think that there are dollar signs in people's minds and not common sense! I am in devils canyon a great deal. It is never overcrowded, almost no litter, most no ecological destruction, it does not need any trail improvements and ultimately does not need to be managed in any way.

Comment: The recent addition to Devils Canyon of "doggie bags" would not be irritating to me if I didn't have to constantly move off trail because I've encountered a large pile of horse droppings directly in my path. Are there plans for horse users to have to pick up their animals excrement? This would only seem fair, I don't see how the impact of horses is any less. Also PLEASE zero ATV use; conservation includes the QUIET experience of hiking as well.

Comment: <a. bad idea> restrict camping/0camping $<$ e. very bad idea $>0$ camping please $<$ g. no answer $>$ I do not go to the National Parks because of pet restrictions; only use BLM areas in the valley

Comment: Annual Pass is applicable

Comment: $<$ d. very good idea $>$ if pass is useable on weekends

Comment: <a. bad idea > people will litter them!

Comment: I LOVE the fact that I can run these trails w/ my lab, Abbey. It gives me and her such joy to exercise in the splendor of these canyons. I often pick up trash in the parking lot while I cool down after a run. Please maintain the low profile nature of the area--that is so much of its chain and allure.

Comment: <No for $\$ 2>$ I have trouble paying to just go trail running--I'll run on the monument trails instead

Comment: <d. now answer > No unless the pass from item "c" does not exclude weekends.

Comment: We love being able to take our dog for long hikes but we were glad to see signs asking people to clean up after their dogs!

Comment: I had a great day at Devil's Canyon and would like to return to do additional day hikes. I would NOT like to see motorized vehicles allowed. I also liked the fact that most of the hiking trails did not allow mountain bikers--it's sometimes scary to share the trail with high-speed bikers. I do think there SHOULD be bike trails in the area. Though. It would be nice to someday have a brochure of the area with a trail map to take along on the hike--maybe charge a small fee for the maps. I think a fee of $\$ 5$ or less is fine. I think more would discourage people from coming. But if fees are changed, there should be an 
annual pass so locals / people who use area a lot don't have to pay so much.

Comment: < didn't answer, but wrote in big letters across the table, "No FEES">

Comment: *With the exception of the rapidly growing elderly day-hiker population, judging by the Comments at the Pollock Bench Log Book. I am sick and tired of the inept, wasteful and biased mismanagement of public lands within the control of the BLM. Forest and foremost, quit classifying mountain bikes as "motorized vehicles". The closest classification would be to pair mountain biking with horseback riding. I have yet to witness one circumstance where an altercation has taken place. Everyone appears to get along on the trails*. Secondly, I am sick and tired of constant trial closures to mountain bikers (and presumably soon to come, runners) when the BLM consistently suckers IMBA and COPMOBA members to come out to help with trail maintenance and then close the trails off to them. I have yet to see ANY members of other special interest groups (I.e. ATV, 4x4s, horse owners) volunteer or self-police the trails, yet most existing areas remain open to their groups. Stop catering to big-business (gas and oil interests) and ranchers. I am tired of subsidizing their businesses. There are plenty of remote areas to "manage" Leave the local accessible areas alone. BLM apparently wants to make the Devils canyon area a tourist attraction at the expense of the locals who have used it for years. It will become another god-damned Mary's Look fiasco. For the most part, the locals now avoid that trail system since it was "developed" for the front range population.

Comment: This survey SAYS Devils Canyon, but questions are more toward CO Cyns total area. Camping would be OK, but near the road only. I would like to be able to backpack. I think it is fair to collect fees from those using the areas, so long as fees are used in those areas. Thanks for seeking out the

Comment: You ask that you pick up after pets!! There is horse poop everywhere!! What's up with that--the horses make the biggest impact--they are there every day--charge them--if you own a horse you have $\$ \$ \$$ !

Comment: It is frustrating to have to pay for every visit to State, National and now BLM land. I would volunteer to clean trails or other activities. I would like to see it undeveloped as possible. I like the condition of the trails in Devils Canyon--just right for day hiking. I also like to hike with my dog and this is a great place for us to go. I do clean up after my dog and keep him close to me. All other horse and dog people I've met have been

Comment: Please leave Devil's Canyon as it is. I actually liked it BEFORE you came and restricted travel and put signs up. It just increases the number of visitors. Leave it alone!

Comment: I believe the Federal Government should put more of my tax dollars to work for Parks and Recreation, including land acquisition, maintenance, supervision, repair and restoration and interpretation. I do mind paying an annual fee for my personal use of these lands on top of my taxes. I do not want to have to pay with each day use. The cost of acquiring and administrating public lands should be shared by all taxpayers. Those who actually use the lands can pay and user fee as well, but that money should go towards maintenance and restriction from use.

Comment: Only saw a little of the area. Was taken there by a resident to see it briefly. Didn't have time to stay long but did enjoy the national setting and would hope you could keep it that way as much as possible. We already have too many beautiful places ruined with recreational use in excess.

Comment: No every piece of BLM land needs to be a fee area. Don't advertise it. Let people find it and use it as is without "improving" it.

Comment: BLM is public land - - for all the public -young and old--rich or poor. I donate all my "free" volunteer time for the good of the public. My talents, skills, knowledge, energy and interests are extensive-as is my desire to give back to the country, people, and community I love. My financial resources are now extremely limited. At this moment I feel defeated and cheated, if public lands are only for those who can afford it. I am sorry it has come to this--I always wanted to be a paleontologist. $<$ respondent name $>$

Comment: Many people are willing to donate their time to help maintain trails, close unnecessary trails, etc. in this community. The BLM needs to do a better job of reaching out to these people to get them to participate in helping to maintain high-use areas. This could eliminate the need for more funds being needed through a fee program. I am extremely opposed to any type of user fees for low impact use such as hiking.

Comment: We live in Colorado and have since I was 2 yrs old, we should not have to pay to go for a hike. Our taxes are high enough! The wilderness should stay the wilderness go to a recreational area, to be paid for: "Wake up and smell the wild roses! Without paying for them" 
Comment: < no answer, writing across table in large letters, "Leave it as is, no change" $>$

Comment: <no answers but large writing across the table, "Leave it as it is, no changes">

Comment: Please don't regulate BLM property as heavily as National Monuments. I enjoy staying to paths. I enjoy the SAFETY of having my canine friend accompanying me on my runs. I've been running the cabin trail for six years. Although the numbers of people have increased, I've not noticed negative changes to the environment. More water holes would be appreciated by both domestic and wildlife. Remove the unsightly port-a-potty. BLM is doing an excellent job of maintaining this remote area!

Comment: <answer yes to $\$ 2>$ probably, more than likely I would be one of those pay and is hoping not to get a ticket.

Comment: I enjoy running on the trails at Devils Canyon. I enjoy not being run over by mountain bikes. We like to bring our puppy for walks. I DO NOT agree with charging a fee! I will not come back to Devil's Canyon if there is a fee. I enjoy having a beautiful / peaceful place to go, so close to home!

Comment: I would like to see drastic changes happen to this area. Keep it a "natural beauty".

Comment: Beautiful area--we need to protect it!!

Comment: <answer no to $\$ 5>$ maybe not, there are lots of other places nearby

Comment: Please protect this beautiful area from ranching. ATV's / off-road vehicles and overdevelopment.

Comment: Spent 8 nights and 7 days in the area. I was impressed by the cleanliness of the area and I hiked and rode horse in. There was very little litter. Unfortunately at the beginning of the hiking trail there was a great deal of dog waste. However, If money is extremely tight it wouldn't be worth it to patrol the area. Once we were on the trail a ways the problem

Comment: Make the arches area in Horsetheif canyon more accessible. Put mileage for trails on signs and brochures; describe type of trail and scenery (easymoderate - difficult, elevation climb, etc.)

Comment: There is no advertising about Devils Canyon on $\mathrm{I70}$ at all. It just happens there are a lot of "Colorado Hot spots" where people should not be allowed to camp. And only "picnic" undesignated areas. Devil's Canyon is a great "Colorado Secret"!
Comment: <didn't answer for \$3> I would prefer an annual pass. At $\$ 3$ per visit, I'd have to look for other places to walk. Maybe that would be good for the area, though!

\section{Dinosaur Hill}

Comment: I loved the wilderness and isolation of Dinosaur Hill. I hope you don't spoil it with too much regulation.

Comment: Your USGS Rep. On site was very polite. Most of the trails were well kept.

Comment: I am dismayed by the increased use of recreational lands but recognize a need to develop them in a planned manner.

Comment: Question \#3 is confusing. There isn't an opportunity to participate in choices: 1, 3-11, 13,14 at this location

Comment: I would like to see the signage worked on at dinosaur hill. The brochure was good, but not all \# ed signs were still standing.

Comment: More signs for directions and a cleaner map would be appreciated Thank you. Good luck.

Comment: Trash bins, allow pets or leash

Comment: A lot of people like us, use the hill as a workout location on weekends. I would not mind paying an annual fee, but I would hate to see any more development at this area. It's natural charm is GREAT. Guided tours on weekends twice a day might be good for visitors in the summer. Allow locals who want to work out, to use the hill as early as $7 \mathrm{am}$ and in the evenings until 8 or $9 \mathrm{pm}$ in the summer when the sun sets later. Toilets would be OK. Parking is OK now.

Comment: The old rule applies: If you develop something in nature people will come and they will run it: protect the hill; don't develop. Provide excellent maps and interpretation: keep it natural. Example, the Hill map is terrible. Legibility, interpretation, printing, Look! At the trail map, can't you read

\section{Rabbit Valley}

Comment: The biggest problems I see at R.V. are, \#1, Dirt bikers making their own trails at will. They've trashed countless acres of public and private land. Add to that no visible enforcement of the rules, 
and the problem continues to worsen. \#2, camping in no

Comment: No fees.

Comment: Only charge non-residents.

Comment: Do not open single track trails to ATV's.

Comment: I love how you are getting people involved to help make Rabbit Valley a better place and thanks so much for helping to fix up the camping spot where NATRC met for the ride. The grave limited a lot of the dust. Thanks a ton again.

Comment: I don't know that Rabbit Valley needs law enforcement in general. I did see the BLM had to remove a discarded camper while we were there. That's unfortunate. I would hope that one user group isn't singled out for misuse of the land. I'm a motorcycle

Comment: I hate the noise \& destruction of trail bikes-just being on their own trails help. There should be areas without noise from these bikes. IEKronks Overlooks Campground. Restricting vehicles and RV to designated trails has helped the area a great deal a

Comment: Rabbit Valley is a great area. One reason it is so great is that it is free. I see no reason to charge people to use public lands. Perhaps the groups(Equine, ATV, etc.)that use the area could help with improvements, trail marking, maintenance or clean.

Comment: The restroom needs cleaning, repair and maintenance. Develop separate trail system for motorized vs non-motorized, road needs grading. Keep separate.

Comment: Thank you for asking my opinion. I love visiting the area \& enjoy every moment. Good luck.

Comment: The park attendants did a great job on site areas and pit toilets. The marked trails were easy to read. Easy to stay on and off appropriate trails.

Comment: The large camping lot (NATRC ride) is horrid! The Rock is helping, but need lots more, please.

Comment: It is a lovely area but I do not see it as a high use area that would warrant employees, rules, fees etc.

Comment: Our group (NATRC), both regionally and nationally, has approved trail funds to be spent improving the camp site we use for our once-yearly trail ride in coordination with BLM. We hope this will benefit other groups as well. If individuals would have to $\mathrm{p}$
Comment: Would like to see the BLM use local clubs instead of fees. belong to two of them and we never hear from the BLM unless we are doing something they do not like. There are also grants available for this kind of stuff. Co HVC, parks etc. No

Comment: Only problem I ever find @ areas like this are that approx 1 in 10?-do not clean up their camp areas. I p/u over ten bags of trash every time. How to regulate? Too many rules ruin the exp. Like very regulate NP campgrounds(ugh) So I guess the other 9

Comment: No fees at all

Comment: The ATV/motorbike traffic is noisy \& dusty-so I would like some hiking areas far from the noise \& dust. Thanks.

Comment: I like the idea of a fee for use area if the fees are used directly for the area they are collected. Have a day users fee as well as an annual pass that is affordable and feasible. I believe if the visitor sees improvements in infrastructures then the $f$

Comment: The only Comment: I have is a general one regarding the land use on BLM lands. It is hypocrisy to talk about ( $\mathrm{sp}$ ) crytopsychotic soil and limiting movement on it while allowing cows to walk all over it and crap everywhere. Get cows off these BLM lands.

Comment: There is a real need for maps of the area that can be taken along the trail. We had a real challenge finding the trailhead and almost gave up. Glad we didn't-Ruby Canyon is

Comment: I only come for the ride. There is a lot of dust in some places that is a turn off. It is a great place to do trail rides because it is big and beautiful. I love what you are doing to help the competitive trail rides. The gravel helped a lot-than

Comment: If you don't know where the "Stinking Desert" is, you should not be doing this survey. It is a large area whose history is parallel to that of what's happening in Rabbit Valley: over-use, planning with little study of the consequences, failure of man

Comment: Many people cannot afford to pay to use these lands. How about a voluntary donation \& specify what it is to be used for? Need to work on roads.

Comment: I would like to see BLM outlaw the use of dirt bikes and ATV's at Rabbit Valley. So many times I have seen them, or see their traces off the trails. They are loud, they pollute the air, and they have no regard for the wildlife and nature. 
Comment: Develop campgrounds w/campsite accessible for car camping(not just 4-wheel drive access)or R.V. vehicles

Comment: One of the great options of BLM land is that it's free. But I understand to maintain its cleanliness, its accessibility \& its natural beauty, money is necessary. I hope that if Rabbit Valley does decide to implement a fee, that they do so with prudence

Comment: Rather than having "police" charging money everywhere that is nice-try to use general taxpayer funds to manage the lands. This is a benefit of being a citizen of the USA. Extractive activities such as oil \& gas could also subsidize recreational mgt.

Comment: Nice place to stop \& rest when traveling E. \& W. on I-70

Comment: No fees.

Comment: The motorized vehicle use(dirt bikes \& ATV's are ruining the Rabbit Valley experience with noise $\&$ and destruction of landscape $\&$ trails. It is blatantly obvious, many pictures have been taken for proof. Why can't we change this? It will soon be for mot

Comment: No fees ever

Comment: I don't have any ideas about the fees. Just don't start charging if you don't have to . Please keep what a good thing you have there.

Comment: No fees at all. Seems to me as soon as an area becomes popular, fees get levied!!

Comment: If you pay taxes no fee. If you don't pay taxes, stay off my land, we are supporting you already

Comment: Have scholarships for people--they would be based on merit, knowledge of good practices-outdoors, use of bikes, etc.

Comment: No fees at all.

Comment: No fees period...I less Smart Bomb would do it...

Comment: Keep the fees low. Perhaps lower rates for $60 y e a r s$ and over and/or for families. Those who are willing and able could donate higher amounts.

Comment: Think that the area should remain as it is-mostly undeveloped and no fee

Comment: $\$ 4$ a day isn't too much to charge to make sure the place isn't torn up by dirt bikes, people won't just trash the place (like Lavender Canyon in Utah)
Comment: 55 cents older fee

Comment: A fee is fine, but only if used to preserve the place. Natural-not commercial.

Comment: Get a job!

Comment: Charge a small fee every day

Comment: No fees at all, use your budget!

Comment: Maybe fees for camping only

Comment: Bring a copy of the latest state or federal income tax form. If below certain limit entry is free.

Comment: Please do not make this area a monument or wilderness. Thank you.

Comment: donations

Comment: please do not collect fees

Comment: As long as weekday-free days were open to all

Comment: Maybe offer services with profit marginslike no day-use fees, but have camping and shower fees and maybe sell water or snacks, etc.

Comment: under 18 years of age

Comment: Have an optional fee box with a suggested amount perhaps based on how much you enjoyed the time spent. Let people's conscience decide.

Comment: I enjoy Ravit Valley as it is. It is a beautiful place and part of that beauty is the fact that it is natural setting, no

Comment: People that can pay for a car, and the gas to get them there can pay $\$ 3$. Busloads of welfare recipients can go in free.

Comment: No Fees!

Comment: No fees period

Comment: No Fees

Comment: Disabled and senior citizens free access

Comment: No fees would ever be charged!

Comment: High fee to hunters. Family fee good for a week. Low fee-(car)

Comment: No opinion

Comment: The great attraction is its pure natural feel. Open space-do not make the place a tourist trap or $\mathrm{RV}$ tour attraction. It's rawness makes it special, plus keeps most people away-the less adventurous crowd.

Comment: We usually ride motorcycles and camp when we come down. Try to come more in winter of course. We come for the trail systems and have spent 
time at the rock art and the fossil trail. A few more bathrooms are a out the only "improvements" needed really.

Comment: I go to parks to ride and play all over Colorado and they all have their special appeal. Rabbit Valley is special because of the set up they have with no gates at the part and you can come and go as you please. I can afford fees and would pay if I had $\mathrm{t}$

Comment: I enjoyed my visit and plan on doing it again. Pleas don't try to fix what isn't broken. It seems like a wonderful place just as it is.

Comment: I like seeing it used. I need an area to hike without the noise of motor sports please.

Comment: I think developing car-camping spots with tire grates and shared toilets is the best thing that can be done. They should be pay sights to help cover costs. When people are required to pay even a minimal user fee the stewardship mentality increases

Comment: I am opposed to fees simply for the fact I participate in the OHV program and have since it began. The monies from the program are supposed to pay for maintenance and other expenses to keep trails and recreational areas open, so far all my experience has

Comment: It still ought to be a pay-to-use area.

Comment: $\$ 2.00$ is not too much for organized rec. use.

Comment: No fees for youth groups No fees off season

Comment: Why not just leave things alone?-no fees at all!

Comment: No fees charged ever. We already pay fees to the BLM in the form of taxes to the Federal Government.

Comment: Push congress/president to fully fund our federal land management agencies. Not good to concentrate use merely because you're poor.

Comment: I greatly appreciate being allowed to ride my motorcycle on the trails at Rabbit Valley. I hope the trails will remain designated as single-track; OHV's should be restricted to the designated twotracks. My experiences with the other users;

Comment: If planning to camp-don't charge an entrance fee! Make camping fee reasonable!-charge an entrance fee if not camping!

Comment: Accept National Park Pass and CO State Park Pass.
Comment: No fees at all

Comment: No fees

Comment: Charge non residents

Comment: The season pass should alleviate this

Comment: When you don't charge consistently it's hard for the public to understand

Comment: Find a way with the resources you have

Comment: A moderate fee

Comment: Senior pass?

Comment: Most people @ L.I. Do work, so not chg during week wouldn't help them.

Comment: Senior passes (yearly or life time)

Comment: Don't promote R.V. as a destination site. Hide it. Soft impact use only. Drought, overgrazing and over use by wheeled vehicles $\&$ fire $\&$ wind has changed it dramatically in just a quarter century. Like the "Stinking Desert," it may never recover.

Comment: Have a "free day" or days to have the opportunity to serve lower income users \& take the time to inform \& educate

Comment: Our family strongly supports fee collection and road maintenance. We could not access McDonald Canyon with our vehicle.

Comment: Keep the fee affordable for anyone.

Comment: No fees! It is not a popular stop. I do not see it like a RMNP or other high use area.

Comment: I fully support management of our public lands for multiple beneficial use but strongly oppose additional user fees particularly considering the disproportionate amount of tax I currently pay as an employer and business owner.

Comment: Fees volunteered as donations rather than collected

Comment: Donation or volunteer fee

Comment: \$2.00 isn't enough to keep anyone out-if you can afford to drive out here you can afford $\$ 2.00$ to enjoy the amenities.

Comment: Charge high impact users i.e. motorized users

Comment: How would making these 2 options help people with limited income? How are you to determine who are limited income people?

Comment: One fee/one week stay

Comment: One day a week is free. 


\section{Comment: $\$ 2$ dollars a day}

Comment: Like an easy way to collect the money-or just collect it from all taxpayers-then we don't have to spend resources checking permits \& writing tickets

Comment: I appreciate very much the use of BLM land, however it is the motorized ATV \& motor cross that cause the damage to the environment more than the hikers and mountain bikers. Thank you.

Comment: Rabbit Valley is a beautiful area. It was a pleasant surprise to see an area with no fees. I am content with Rabbit Valley staying the way it is. On busy weekends it may need more camping sites though.

Comment: It would be great if you had motorized trails separate from mechanical or hiking trails! Like the idea of hiking \& horse trails together! Improve the road in spots! I noticed improvement in the drainage! You should charge a reasonable price because of

Comment: I think a fee would be a slow thing to do besides if you charge a person then you would have to police. Fraud flat would drive your costs over what it costs don't be stupid.

\section{Comment: Volunteers}

Comment: No fees at all

Comment: Charge fees for motorized vehicles ie. Motocross, and camping overnight.

Comment: Charging fees to use Rabbit Valley and etc. is a very bad and unworkable idea. It is counterproductive and simply creates animosity between the public and the federal agency. The Forest Service found it did not work at Yankee Boy Basin in the San Juan's
Comment: There should be less roads and small parking areas. One or two big ones with a variety of trails suited for different activities leaving the parking areas would greatly improve the overall experience. Also, whole sections should be restricted to nonmotor

Comment: I have only experienced positive, respectful trail etiquette and yielding from my fellow trail users(I.e. mtn bike, ATV, motocross, cars/trucks) Please don't pave a thing!

Comment: Stagger fees based on their impact on environment(I.e. motorized pay more than $\mathrm{mtn}$. Bikes, mtn bikes pay more than hikers)

Comment: Give them a pass which would allow them to forgo charge.

Comment: Free fees on some holiday weekends.

Comment: It's important to strike a balance between conservation and recreation. Collecting fees is ok to have additional resources to find this balance.

Comment: No fees period.

Comment: Low income pass (based on tax returns)

Comment: No fee for 1 day use. Fee for camping, rafting other special use fee for maps etc ok Big fee for stuck vehicles!!

Comment: Charge commercial users-extractive industries \& guide/outfitter services-particularly commercial rafting

Comment: Charge 3 or 4 dollars every day

Comment: Part of the beauty of the area is lack of people therefore if a fee keep them away as well as underdevelopment then keep it that way please!

Comment: No fees. My tax should pay for all public land use. 


\section{Appendix C}

Attentive Public Survey - Question Summaries 
In this section of the report are the findings and summary statistics for each question that appeared in the survey. Data used in these analyses were collected from the 203 returned, mail back surveys.

1. The BLM would like to know where you spend you time when you visit Colorado Canyons NCA. (Please choose the ONE area where you spent the most time this year. This location will be used to respond to the rest of the questions in this survey.)

\begin{tabular}{l|c|c}
\hline \multicolumn{1}{c|}{ Colorado Canyons NCA Location (n=203) } & N & Percent (\%) \\
\hline Rabbit Valley & 72 & 35 \\
Kokopelli's Loops/Mack Ridge & 27 & 13 \\
Colorado River/Loma Boat Launch & 33 & 16 \\
Devil's Canyon & 27 & 13 \\
Dinosaur Hill & 7 & 3 \\
Pollock Bench & 15 & 7 \\
Other & 12 & 6 \\
No Answer & 10 & 5 \\
\hline
\end{tabular}

2. Is this your first time visiting this location? $(n=198)$

$\begin{array}{ll}9 \% & \text { YES } \\ 86 \% & \text { NO } \\ 5 \% & \text { No Answer }\end{array}$

3. How would you rate your overall experience? $(n=198)$

$\begin{array}{ll}48 \% & \text { Excellent } \\ 40 \% & \text { Good } \\ 6 \% & \text { Fair } \\ 1 \% & \text { Poor } \\ 5 \% & \text { No Answer }\end{array}$

4. Please circle all of the activities you participated in at this location within the past year.

$\begin{array}{llll}73 \% & \text { Day hiking } & 29 \% & \text { Kayaking/rafting/canoeing } \\ 21 \% & \text { Walking/running } & 7 \% & \text { Fishing } \\ 21 \% & \text { Picnicking } & 7 \% & \text { Sunbathing/swimming } \\ 25 \% & \text { Mountain bike riding } & 33 \% & \text { Viewing fossils or rock art } \\ 9 \% & \text { Motorcycle or OHV riding } & 50 \% & \text { Wildlife watching } \\ 16 \% & \text { Backpacking/Backcountry } & 64 \% & \text { Scenery } \\ \% & & 45 \% & \text { Photography } \\ 11 \% & \text { Camping near vehicle } & 4 \% & \text { Motor-boating } \\ 10 \% & \text { Horseback riding } & 4 \% & \text { Hunting camp }\end{array}$


4a. From the list above please rank in order of importance your three main activities at this location within the past year.

\begin{tabular}{cccl}
\hline \multicolumn{5}{c}{ Order of importance (\%) } & \\
\hline 1 st & 2 nd & 3 rd & \\
31 & 21 & 9 & Day hiking \\
2 & 5 & 3 & Walking/running \\
1 & 2 & 1 & Picnicking \\
13 & 4 & 3 & Mountain bike riding \\
7 & 1 & 2 & Motorcycle or OHV riding \\
3 & 4 & - & Backpacking/Backcountry \\
- & 3 & - & Camping near vehicle \\
8 & 2 & 1 & Horseback riding \\
11 & 4 & 3 & Kayaking/rafting/canoeing \\
- & 2 & 1 & Fishing \\
- & 1 & 1 & Sunbathing/swimming \\
4 & 3 & 8 & Viewing fossils or rock art \\
2 & 8 & 12 & Wildlife watching \\
3 & 23 & 21 & Scenery \\
2 & 4 & 12 & Photography \\
2 & 1 & 1 & Motor-boating \\
1 & - & 2 & Hunting camp \\
4 & 9 & 15 & No answer \\
\hline
\end{tabular}

5. Please tell us more about your visitation experience by indicating how important each item was to that experience at this location.

\section{Experiences at this location}

This experience helped me to better understand the environment and the history of the area.

This experience helped me slow down and relax for a while.

I did something here that I have never done before.

I was able to share this experience with my family.

This time allowed me to enjoy a range of physical challenges.

I was able to be in an active and dynamic setting instead of reading about it.

It was intellectually stimulating

I was able to enjoy physical exercise in a natural environment.

This time allowed me to get away from a developed setting to a natural setting.

\begin{tabular}{|c|c|c|c|c|c|c|}
\hline 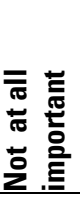 & 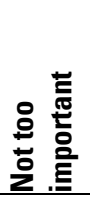 & 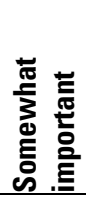 & 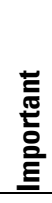 & 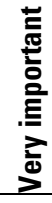 & 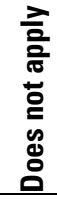 & 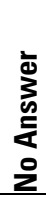 \\
\hline 2 & 5 & 25 & 36 & 20 & 6 & 4 \\
\hline 3 & 7 & 12 & 34 & 37 & 4 & 3 \\
\hline 18 & 10 & 11 & 7 & 5 & 42 & 6 \\
\hline 9 & 4 & 10 & 36 & 19 & 18 & 4 \\
\hline 7 & 8 & 25 & 29 & 23 & 3 & 5 \\
\hline 4 & 6 & 8 & 34 & 37 & 5 & 6 \\
\hline 6 & 12 & 23 & 24 & 15 & 13 & 7 \\
\hline 1 & 3 & 14 & 27 & 49 & 1 & 5 \\
\hline 1 & 3 & 8 & 26 & 56 & 2 & 4 \\
\hline
\end{tabular}


6. Do you plan to return to this location? $(n=202)$

$\begin{array}{ll}95 \% & \text { YES } \\ 4 \% & \text { NO } \\ 1 \% & \text { No Answer }\end{array}$

7. How many visits have you made to this area in the last 12 months $\underline{12.2}$ (Mean \# of visits).

8. How did you learn about this area?

Friends

Recreation Group (OHV club, hiking group, etc.) $17 \%$

BLM Staff

Visitor Brochure

Family

Travel Guidebook

Local Tourism Information Center

BLM Web site

Highway signs

Hotel Staff

Other web site

Magazines

Other

I live in this area, I grew up here, Other media sources, Personal knowledge

9. What was your one-way travel time form your home to this area; long does it generally take for you to get here? $(n=200)$

\begin{tabular}{|c|c|c|c|c|}
\hline 0 to 2 hours & 3 to 5 hours & 6 to 8 hours & 9 to 12 hours & More than 12 hours \\
\hline $49.2 \%$ & $24.6 \%$ & $10.4 \%$ & $8.8 \%$ & $7.3 \%$ \\
\hline
\end{tabular}

10. Including yourself, what was the number of people in your group who traveled with you on this most recent visit to this location? $(\mathrm{n}=198)$
1-5 people
6-10 people
11-20 people
More than 20 people
$6 \%$
No answer $3 \%$

11. What was the amount of time you spent at this location? $(n=198)$

$\begin{array}{ccccccc}\begin{array}{c}\mathbf{1} \text { day } \\ \text { or less }\end{array} & \mathbf{2} \text { days } & \mathbf{3} \text { days } & \mathbf{4} \text { days } & \mathbf{5 - 1 0} \text { days } & \begin{array}{c}\text { More than } \\ \mathbf{1 0} \text { days }\end{array} & \begin{array}{c}\text { No } \\ \text { answer }\end{array} \\ 6 \% & 13 \% & 6 \% & 2 \% & 2 \% & .5 \% & 71 \%\end{array}$


12. Listed below are a few management questions for this location. Please indicate what you think about the following management options? $(n=203)$

\begin{tabular}{|c|c|c|c|c|c|c|}
\hline Management options & 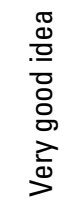 & 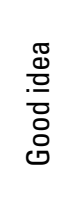 & 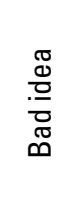 & 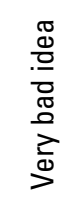 & 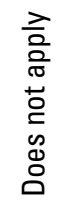 & 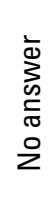 \\
\hline $\begin{array}{l}\text { Developing more recreational experience opportunities at this } \\
\text { location }\end{array}$ & $13 \%$ & $17 \%$ & $30 \%$ & $30 \%$ & $2 \%$ & $8 \%$ \\
\hline $\begin{array}{l}\text { Not developing any facilities, and manage the area for } \\
\text { undeveloped use only. }\end{array}$ & $43 \%$ & $16 \%$ & $16 \%$ & $13 \%$ & $5 \%$ & $7 \%$ \\
\hline $\begin{array}{l}\text { Restricting recreation at this location to limit impact on rare } \\
\text { plants and wildlife species. }\end{array}$ & $27 \%$ & $31 \%$ & $17 \%$ & $11 \%$ & $6 \%$ & $8 \%$ \\
\hline $\begin{array}{l}\text { Developing a series of motorized off-road vehicles trail loop, } \\
\text { managing for all terrain vehicles and motorcycle use. }\end{array}$ & $12 \%$ & $10 \%$ & $17 \%$ & $54 \%$ & $2 \%$ & $5 \%$ \\
\hline Adding day use areas such as picnic areas, etc. & $8 \%$ & $36 \%$ & $23 \%$ & $22 \%$ & $3 \%$ & $9 \%$ \\
\hline
\end{tabular}

13. If fees were collected at the Colorado Canyons NCA, the money could be used in a number of ways. Please indicate the response that best represents what you think. $(n=203)$

\begin{tabular}{|c|c|c|c|c|c|c|}
\hline Money collected from fees at this location should be spent on & 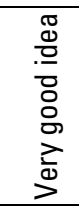 & $\begin{array}{l}\text { 요 } \\
\text { 음 } \\
\text { 옴 }\end{array}$ & 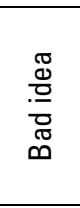 & 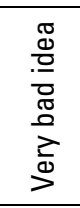 & 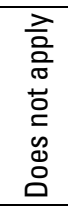 & 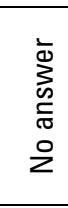 \\
\hline $\begin{array}{l}\text { Educational and interpretive materials such as maps and } \\
\text { brochures }\end{array}$ & $20 \%$ & $49 \%$ & $10 \%$ & $8 \%$ & $.5 \%$ & $12 \%$ \\
\hline Guided tours of the area & $3 \%$ & $21 \%$ & $27 \%$ & $33 \%$ & $5 \%$ & $12 \%$ \\
\hline Toilets and parking & $17 \%$ & $48 \%$ & $16 \%$ & $7 \%$ & $2 \%$ & $10 \%$ \\
\hline Roads and trails & $18 \%$ & $43 \%$ & $12 \%$ & $12 \%$ & $2 \%$ & $13 \%$ \\
\hline Law enforcement & $26 \%$ & $41 \%$ & $8 \%$ & $11 \%$ & $3 \%$ & $10 \%$ \\
\hline Camping areas & $10 \%$ & $31 \%$ & $27 \%$ & $16 \%$ & $3 \%$ & $12 \%$ \\
\hline Wildlife/habitat protection & $47 \%$ & $27 \%$ & $5 \%$ & $1 \%$ & $6 \%$ & $11 \%$ \\
\hline Protection of dinosaur fossil locations & $48 \%$ & $25 \%$ & $6 \%$ & $2 \%$ & $4 \%$ & $14 \%$ \\
\hline
\end{tabular}


14. To what extent would you agree or disagree with the following fee-permitting options for the Colorado Canyons NCA. (For each statement, please circle the number that best represents your level of agreement.) ( $n=203)$

\begin{tabular}{|c|c|c|c|c|c|}
\hline & 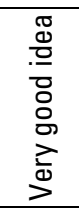 & 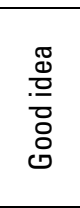 & 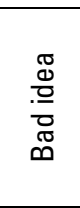 & 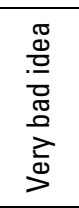 & 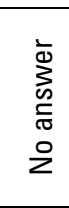 \\
\hline $\begin{array}{l}\text { Different fees for different lengths of recreational stay (for } \\
\text { example, a week versus a day) }\end{array}$ & $19 \%$ & $42 \%$ & $9 \%$ & $13 \%$ & $17 \%$ \\
\hline Different fees for residents versus non-residents & $13 \%$ & $10 \%$ & $37 \%$ & $26 \%$ & $14 \%$ \\
\hline $\begin{array}{l}\text { An annual pass that includes the Colorado National Monument } \\
\text { and the Colorado Canyons National Conservation Area }\end{array}$ & $26 \%$ & $42 \%$ & $7 \%$ & $12 \%$ & $12 \%$ \\
\hline $\begin{array}{l}\text { An entrance fee for high-use periods such as holidays and } \\
\text { weekends. }\end{array}$ & $12 \%$ & $28 \%$ & $24 \%$ & $20 \%$ & $16 \%$ \\
\hline A fee for specific recreation use, such as the use of camping sites & $19 \%$ & $43 \%$ & $13 \%$ & $8 \%$ & $16 \%$ \\
\hline $\begin{array}{l}\text { An annual pass that would allow you to visit all BLM locations as } \\
\text { often as you would like }\end{array}$ & $31 \%$ & $34 \%$ & $10 \%$ & $12 \%$ & $14 \%$ \\
\hline $\begin{array}{l}\text { An annual pass for all the areas within the region managed by } \\
\text { different federal agencies (e.g. U.S. Fish and Wildlife Service, } \\
\text { National Park Service, U.S. Forest Service, and the BLM). }\end{array}$ & $32 \%$ & $28 \%$ & $11 \%$ & $13 \%$ & $15 \%$ \\
\hline
\end{tabular}

15. If the BLM were to charge an entrance fee at the Colorado Canyons NCA, would you have still made this visit today? ( $n=203$ )

\begin{tabular}{c|c|cc}
\hline Entrance fee amount & $\mathbf{N}$ & No & Yes \\
\hline$\$ 1$ & 36 & $16 \%$ & $22 \%$ \\
$\$ 2$ & 28 & $4 \%$ & $22 \%$ \\
$\$ 3$ & 52 & $24 \%$ & $23 \%$ \\
$\$ 4$ & 52 & $28 \%$ & $23 \%$ \\
$\$ 5$ & 35 & $28 \%$ & $9 \%$ \\
\hline
\end{tabular}

16. If NO, why not

$6 \% \quad$ I would pay but not this much

$2 \% \quad$ I cannot afford to pay this amount of money

$3 \% \quad$ It is unfair to expect me to pay for better management of these lands

$17 \%$ I am opposed to paying for the use of public lands for recreational purposes

$3 \% \quad$ I am opposed to paying the government for the maintenance of these public lands

$2 \% \quad$ I come here now because it is free

$12 \% \quad$ Other

17. If the BLM collected a recreation fee (refer to your location in question 1) at this location, how likely would the fee affect your visits to this location in the future?

43\% I would continue to use this location just as frequently in the future

$27 \% \quad$ I would visit this location less often in the future

$1 \%$ I would do some other activity at this location

$20 \%$ I would do the same activity I did today, but at a different location

$2 \% \quad$ I would do a different activity at a different location

$5 \% \quad$ No Answer 
18. If a fee were collected at this location, people with limited income may stop visiting this location. The BLM would like to know which fee option would allow people with a limited income to continue to visit this location. To what extent would you agree or disagree with the following fee permitting options for people with limited income. $(n=203)$

\begin{tabular}{|c|c|c|c|c|c|}
\hline & 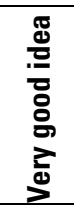 & 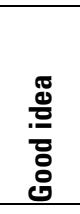 & 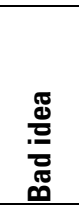 & 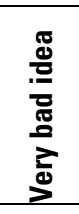 & 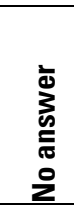 \\
\hline No fees would be charged on weekdays & $21 \%$ & $26 \%$ & $23 \%$ & $9 \%$ & $21 \%$ \\
\hline $\begin{array}{l}\text { An annual pass would be available at a reduced rate that is } \\
\text { reserved for people with a limited income }\end{array}$ & $17 \%$ & $30 \%$ & $20 \%$ & $14 \%$ & $19 \%$ \\
\hline Other & $17 \%$ & $3 \%$ & $1 \%$ & $3 \%$ & $76 \%$ \\
\hline
\end{tabular}

Summary of socio demographic questions.

\begin{tabular}{|c|c|c|c|}
\hline Socio demographic variables & Frequency & Percent & Mean \\
\hline \multicolumn{4}{|l|}{ Gender ( $n=196)$} \\
\hline Male & 145 & 73 & \\
\hline Female & 52 & 27 & \\
\hline Age & & & 53.5 \\
\hline \multicolumn{4}{|l|}{ Education ( $n=196$ ) } \\
\hline High School/GED & 11 & 6 & \\
\hline Some College/ Associate Degree & 41 & 21 & \\
\hline College Graduate & 63 & 32 & \\
\hline Post Graduate degree & 81 & 41 & \\
\hline \multicolumn{4}{|l|}{ Income ( $n=154)$} \\
\hline Less than $\$ 10,000-24,999$ & 12 & 7 & \\
\hline$\$ 25,000-49,999$ & 31 & 20 & \\
\hline$\$ 50,000-74,999$ & 58 & 38 & \\
\hline$\$ 75,000-99,999$ & 38 & 25 & \\
\hline More than $\$ 100,000$ & 15 & 10 & \\
\hline \multicolumn{4}{|l|}{ Occupational Status ( $n=195$ ) } \\
\hline Retired & 62 & 32 & \\
\hline Not Retired & 133 & 68 & \\
\hline \multicolumn{4}{|l|}{ Place of Residency ( $n=191$ ) } \\
\hline Mesa County Resident & 143 & 75 & \\
\hline Non-Resident & 48 & 25 & \\
\hline
\end{tabular}




\begin{tabular}{l|cc}
\hline \multicolumn{1}{c|}{ Total household income $(\mathbf{n = 1 5 4 )}$} & Frequency & Percent \\
\hline$\$ 10,000-14,999$ & 2 & 1.0 \\
$\$ 15,000-24,999$ & 10 & 6 \\
$\$ 25,000-34,999$ & 10 & 6 \\
$\$ 35,000-49,000$ & 21 & 14 \\
$\$ 50,000-74,999$ & 58 & 38 \\
$\$ 75,000-99,999$ & 15 & 10 \\
$\$ 100,000-149,000$ & 30 & 19 \\
over \$150,00 & 8 & 5 \\
& & \\
\hline
\end{tabular}




\section{Appendix D}

Attentive Public Survey - Respondent Comments 
This section of the survey was reserved for openended comments. In most cases these responses have been edited for spelling and formatting only.

Comments: The BLM is a crucial and very important entity in the preservation and protection of our natural lands. It is our increasing perception that the emphasis of the BLM and many lands in Colorado is a bias to development and more intensive and inappropriate uses and activities on these lands. It seems the needs for short term exploitation or inappropriate uses such as off-road vehicles is taking precedent over the need for long term balanced preservation and appropriate human activities on these lands. We are active users of recreational low impact visitation to these lands and it seems most of the citizens of this state would agree with this. Often more local and intrusive users are given too much influence over these decisions. These lands belong to all not just those whom by reason of geography or location may be closer to these areas.

Comments: We see a lot of private parties who do not know "leave no trace" environmental principles or choose to ignore them. We go with a commercial outfitter who teaches us all "leave no trace" camping etc. Oftentimes we end up picking up after private parties. We'd like to see more enforcement (an possibly pre-enforcement) to ensure private parties know the rules and come prepared with necessary equipment for protecting the environment. We'd also like to see the public have the ability to report offenders we see on the river (e.g. DOW operation game thief where hunters can turn in fellow hunters disobeying the law). We strongly do not want motorized vehicles such as jet skis or motorboats on our canyon rivers where we come to get away from the noise. Restrict these motorized vehicles to lake reservoirs rather than our rivers

Comments: You know that you are going to charge to breathe in this area so why the survey! If people want to make a donation let that be - I'd rather give that way. BLM id becoming the National Park Gestapo clones. Let people pack in and out and keep pristine. When you closed Pollock Canyon to 10 years of mountain bike history - that was a clear example! Still irks me.

Comments: People with "limited Income" probably won't pay a lot of taxes to ask me for a user fee would be "double dipping"
Comments: There has been a tremendous growth in the number of official vehicles being used for recreation. There is a need for adequate recreation facilities to provide for recreation (motorized recreation). Now is the time to step up. Please do so.

Comments: I fundamentally dislike fees for most public land use. They (the fees) tend to inhibit spontaneous and short duration uses of the area. They seem to me to generate associated expensive bureaucracies. I feel like this questionnaire is structured to administratively justify the institution of fees whether or not he respondent is for or against them - I hope that I am wrong

Comments: I wouldn't mind a combination "park pass' if I were sure monies stayed in the district and not go to Washington DC! With improved signage, roadside kiosks, vault toilets, enforcement (we the public) need to either pay up or help out. It seem most recreationists don't have (haven't learned) ethics. Some remote small scale (4-5 sites) camp spots with vault toilets and fire grids seem proper. Also requiring approved portable toilets (like PETT) would be a good idea in areas of high impact camping. More enforcement of errant (quad OHV) operators.

Comments: I have been actively mountain biking and hiking in this area for the past 25 years. I pay excessively high taxes and feel strongly that the monies I contribute to the government should cover any and all cost towards using our public lands. The Kokopelli's trail system is a gem but should not cost the public to use it. The decision to close Pollock Bench trail to mountain biking was in my mind one of the worse decisions made regarding the use of our lands in this area . I rode that trail for years, never disturbing any wildlife. I am sure that the number of visitors to the area has decreased. There clearly is a balance between government (BLM, FS) can provide with the resources they are given, but I feel lands in our area do not need high tech infrastructures and should remain open to the public without charge. Pollock really needs to be re-opened to mountain biking - you can ride a horse on the trail and not a bike?

Comments: I am a hiker - using many of the locations mentioned to hike. Of late I hike most often on the K-trail, segments of the Loma area. To me I have no quarrel with the way things are now. However, I do not use these trails on the weekend as I am retired. I have not yet had a conflict with bikers 
(I am also a biker). I usually hike with a hiking group of 20-30 people

Comments: This area was set up to allow all existing users. So don't start restricting activities. At the same time be careful how accessible you make it. Now that it is being promoted you will probably overwhelm the whole area.

Comments: I think that the Pollock Bench Trail system should be re-opened for use by the mountain biking community. I could not believe it when Pollock Bench closed to mountain biking - it was one of my most favorite places to ride my mountain bike - because I could ride my bike from my Fruita home and back, and have a wonderful riding experience.

Comments: In general I dislike the idea of paying of my typical use of public lands - hiking, photography and studying rocks. That said, I don't strongly object to paying something extra for the protection of special plans like the National Parks and Monuments. What I object to is someone sitting at Rabbit Valley wanting my money every time I want to see what's going on at the quarry. I doubt if such an effort pays for stuff. If the money collected stays with the NCA, I would be O.K. with an annual pass, but if it goes back to Washington - I'd say forget it.

Comments: I think fees for public lands are a bad idea in general. Our society should encourage outdoor recreation by keeping it free for all, however, if you insist on fees that should apply equally to all. Creating division creates cheating and ill will among users

Comments: Obviously, I am against fees for the mere use of public lands. I am not against paying for a campground, river launch, etc. But to merely enter an area - that is wrong. I already pay for it in my federal income taxes. The land is MINE. Not the BLM's or USFS. You are on the caretakers. Off-road motor vehicles mist be limited and confined. They are ruining the backcountry. This nemesis is worse than cattle!

Comments: Overall I am ambivalent about applying the fee demo program to the CCNCA at this time. If we have a fee requirement, the most import provision will be to provide frequent users with the opportunity to have a pass for unlimited use for a year. The pass shouldn't cost more than $\$ 50$, which is what Colorado State parks charge for an annual pass. A single use pass should be less than $\$ 5$ and be good for 2 days.
Comments: I really miss the way this area was 10-15 years ago with fewer people and fewer regulations

Comments: On Rabbit Valley - open a few of the trails that you closed. Stop with the Carsonite Forest, spend the money on something useful. Maybe have the people or person taking care of Rabbit Valley be more polite or social. Open more camping areas use the money for this rather than the carsonites.

Comments: Well it is obvious that this survey is about money. My problem is once you start collecting money we the people, who own the "public lands" lose our right to access public lands unless we give money. We have no way of commenting on increases once the user fee is established. However, I do believe the issue of motorized vs. non-motorized recreation is becoming big enough of an issue that the two groups need to be separated! Restricted travel should be established, no more free riding on public lands. Money spent for this purpose would be worth it. It is imperative for a quality backcountry experience - especially on the river corridor. The birds and animals asked me to tell you people this! They seem to have lost their right to exist in the white man's world. I also love my quiet time into his area. Hope we can still find it in the future

Comments: Why are the river corridor and the Loma ramp included in this survey? Both are EXCLUDED from the Colorado Canyons NCA. The ramp is on DOW property. I strongly protest BLM including both as a part of the Colorado Canyons NCA questionnaire.

Comments: It is most important to restore these areas for wildlife habitat. If recreation in any form adversely impacts nature species - it should be restricted. As the Grand Valley grows and these areas are visited more frequently, limiting the number of users is a good idea. The major problem on BLM lands is irresponsible motorized use!

Comments: This is the most beautiful area of the country. We need to preserve and protect it

Comments: Other than wilderness areas and paleo research areas. Locations should be open to rock collecting

Comments: This survey appears to have a real bias. No opportunity was provided to oppose fees on BLM lands. While I understand that more revenue would provide more service - I cannot support fees simply to access public lands. If you like go ahead and make the toilets - "pay as you go." Just keep the fees directly related to the service not the access. 
Comments: Designate overnight campgrounds with fire pits and toilets. Fees for overnight only - use money to pay for campsite and rangers. Better boat ramp for motorboats

Collection of user fees is a good idea, but residents who use the area year round should not have to pay a daily fee. Some type of annual pass would be a better idea. I think a daily fee at the Kokopelli's trail head is a good idea for out of town visitors. Camping would be o.k. too if fees were collected.

Comments: I like to have access to areas with signs so one can find the trailhead. Something is needed to keep people on the trail heads - nothing fancy - very basic things. Also accurate little maps (inexpensive) that provide up-to-date information are helpful. Sell these for a moderate price.

Comments: This area is fantastic! I like the idea of different areas for different user groups (e.g. Mack Ridge for mt bikes; Rabbit Valley for motorized; Black Ridge W.A. for equestrians; Colo River for rafters (non-motorized) ). Keep horses off Mack Ridge. Keep mt bikes out of Black Ridge W.A. Keep jeeps out of Mack Ridge

Comments: The only say from Glade Park to the Colorado Canyon is a rancher's (Gore). The private land-owner should also have a say. The fact is BLM wants an ass kisser.

Comments: I enjoy participating in many outdoor activities. The main reason for this is to get out of town and enjoy nature. I am pleased with your efforts to allow different activities in this area. It is never a good thing when a trail is shut down for any purpose. Please continue to work on plans that share our public lands, will allow users (hikers, bicycles, motorcycles, rafters, kayakers, horses, etc) instead of closing lands to limited use by hikers only. I also know that your resources are limited, but charging fees fro use of public lands is ridiculous and adds unnecessary facilities to outdoor experiences.

Comments: It is good that this splendid area is protected and that a range of activities from $\mathrm{OHV}$ use, bicycle use to back packing and hiking are available. How about getting behind the idea of an NCA including the Dominguez Canyon - Bangs Canyon area? We could develop different area there for similar uses.

Comments: The local BLM's bias in favor of destructive forms of recreation is evident at every turn, but has been particularly evident throughout this RMP revision process. The local manager saw to that there was no committee participation by a member the environmental community (her

"recommendations" as to committee membership was apparently "rubber stamped" at the State BLM level. It is difficult to imagine that the responses to this survey will have any impact on the BLMs management of any area within the Grand Junction BLM area's jurisdiction, since the management policy is predetermines by Ms. Robertson and her selection of only like-minded people

Comments: Over the last 20 years, I have seen many changes made to protect the area (Devil's Canyon), particularly signage and trail designation. It is my assumption that this area is primarily as day-use area. Horses have somewhat dominated the use of the area at this point but it is still used by many for walking, running, and hiking. As it is quite accessible, it does seem important that the area be protected from misuse and vandals. If a fee would assist with this then you might get people like myself to "buy in." If you are going to continue to make improvements such as picnic areas, you will loose support from people like myself

Comments: Do not expand the development. Much of the area encompassed by the NCA is pristine (Knowles Canyon). Encouraging visitation in these areas will ruin them. Fee for up keep of a campsite or a picnic area are acceptable, but overall fees to recreate on public lands are wrong until grazing, logging and mining pay sufficiently for their use. Remove all subsidies, then fees make sense. Guided tours and outfitters use of the NCA except of the river and hiking trails should be banned. The area s are too small and fragile for such use

Comments: From my observations mountain biking is by far the greatest land impact. Establish a fee system to address this use. The rafting community has user fees, the OHV user has registration fees - so how difficult would it be to come up with an equitable fee system using a mix of existing systems to develop a fee structure that would address the impact created by bike use and leave the casual low impact users alone. I certainly think that a program along those lines would be much easier to "sell" than trying to implement a blanket fee program.

Comments: I enjoy the rugged wilderness qualities that the NCA offers. My family and I prefer nonmotorized recreation and value areas where we can experience our public lands without the noise and disturbance that $\mathrm{OHV}$ use produces. Please consider limiting areas with OHVs are permitted and just as importantly, set up buffers between OHV areas and quiet use areas. I strongly support quiet use concept 
in management of the Rabbit Valley and the Mack Ridge areas. I strongly support limiting OHV to existing trails only

Comments: I am a former RAC member, I am very interested in public lands for now and the future. People are confused about what to expect. Keep management simple (KIS). Rules and discounts for seniors are difficult to understand. Keep things simple and be truthful with the public.

Comments: I feel that the demographics of the Colorado Canyons NCA user base is reasonably affluent and that the vast majority of users access CCNCA areas by private vehicles. Since the CCNCA is located within convenient and short driving distance to well established recreational user infrastructure and improvements in the SH 340/Fruita area I would not be a supported of many overnight oriented infrastructure improvements (e.g. camping adjacent to trailhead access points or within close proximity to them). I believe that adequate opportunities exist for private capital to provide needed infrastructure close by to existing settlement roads using tax revenues or user-fee generated monies to make improvement on existing public lands located within the NCA will be both a poor use of public money and impact the ability of private capital and property located in properly planned zoned areas to be developed to serve this group and, possibly of the greatest impact, degrade the quality of this conservation area.

Comments: I oppose any access fee for public lands

Comments: Please prohibit jet skis in the river corridor! Cattle grazing within wilderness needs to be better monitored and allotments reduced if the land cannot sustain the use

Comments: Fee collection is a very bad idea! These are public lands

Comments: Would have been easier to complete the survey if a map of the NCA had been provided. I know exactly what areas are inside the boundaries.

Comments: I am the director of the Canyonlands field institute. We hold BLM permits to conduct river trips Loma - WW. Mostly we work with school groups and other educational groups. Crowding and congestion is BAD at Loma and in Ruby Horsetheif on weekends. Please assign/coordinate campsites and require/limit private boating trips at least on weekends (May through August)

Comments: I live in daily awe of our state. Anything you can do to stem the tides of over use, over development, preservation and conservation will serve us all, who live here now and the many who will come after us.

Comments: Pursue wild and scenic rivers status for Ruby/ Horsetheif Canyons. Prohibit motorized craft and vehicles with in earshot of the river.

Comments: Priority needs to be given to wildlife, plant life and habitat protection. If we as a society should fail in this area recreational uses, whether they are simple walking or more complex modes of recreation will be so greatly diminished the conservation areas will be less likely to be visited and supported. Please preserve the natural beauty by encouraging the balance of nature. So many generations beyond our life-time can enjoy them as we have. BLM needs to be the leader in stewardship on our lands.

Comments: My job is that of habitat management ranch lands for 20 years. The proposed fees are absurd. We must remember that the American people have basically told congress that we do not want to continue to increase spending by the Forest Service and BLM - for land management. This is why we created user fees for areas like Maroon Bell's ext it is government's waylay to circumvent the wishes of the people and continue to increase their funding for development of this area. We would like to see things manage in these areas as they were 20 years ago. Also if you put in a fee all you do is transfer usage times to others.

Comments: Bush and Cheney's push to open scenic and relatively pristine areas stinks. No oil/gas/mining. Keep areas low key, minimal road maintenance away from freeway. "Less is more." BLM needs to act like Forest Service with a mission to preserve, not develop.

Comments: I am interested in your process of selecting wilderness areas. I understand there are many special interest groups who participate in your meeting, bikers, OHVs, backpackers, etc. Do you have a voice for seniors and young families. Our families have enjoyed spring picnics in Main Canyon for several years. The grand children enjoy the streams, tad poles, wildflowers, rocks and wild horses. It is close to the population centers and has been open for years. My concerns is for those who are locking up these areas

Comments: Please don't open he NCA to off-road vehicle use

Comments: Please keep oil/gas exploration out of the NCA. Manage the unit for its wildlife, natural cultural and archeological values as outlined in the 
proclamation/congressional legislation. Preserve the pristine quality of unit. Keep abusive ORV to existing trails. Hire more FTEs to help with visitor safety, information, and monitoring

Comments: Require kitchen tarps of river users.

Comments: I grew up using this area. As more time goes by the area is getting more restrictive - I Don't LIKE IT! Instead of building more interpretive trails, put the funds toward a law enforcement officer to monitor what is currently out there. Leave the area alone - no more trails. Open Pollocks back up to Mt biking. Final thought - NO FEES!

Comments: Restrict the number of motorized conveniences. While mountain bikes are mechanized they are quiet. Put the yahoos either 4-wheelers out at the Go-Kart track east of GJ. Don't let Rabbit Valley be the Yellowstone of ATVs!

Comments: At this area and at all areas, need to examine that is driving up the cost of maintaining the resource. 1) Are there options to the major funding of pot surveillance in Sequoia? 2) are we spending \$2.4 million to monitor Yellowstone snowmobiles? 3)

Does the resulting delayed maintenance cost twice as much? 4) How many energetic and successful BLM employees are told NOT to get things done? 5) Colorado State Parks receive annual fees for off-road machines. New trails are developed with much of this funding. Does State Parks receive regular reports re: damaged trails or illegal trails with requests to be reimbursed?

Comments: Improve access to Rattlesnake Arches by remaining unpaved. Create OHV trails in other parts of the NCA. Create hiking trails (loops) if less distance than current trails.

Comments: I have lived in the Grand Junction area for over 30 years and I am very concerned about the use of our public lands in this area. They are in far worse condition now that when we moved here Rabbit Valley in particular. There are 2 main problems: too many people use and abuse them and most of the abuse is due to wheeled vehicle use. I am very much in favor of a plan that closes of or greatly limits use of areas for long periods of time to allow the land to recover on its own. This would also help break habits of people that caused the destruction of the land. I've seen how well this works in BLM land just behind Kingsview Estates and would like to see it implemented elsewhere, including Rabbit Valley. 5-10 year periods are not unreasonable and then reopen the areas. The only expense would be fencing and maybe seeding.
Comments: Don't let this area be destroyed by users who do not obey the rules.

Comments: Instituting fees is a bad idea! If fees are deemed necessary to provide better management and limit use, let regular mountain bikers trade volunteer services (we do it already) for annual passes. Please do no do anything to improve access to the Black Ridge Wilderness Area.

Comments: Many of my answers were based on past experience, some of them 15-20 years ago. I am now almost 80 years old, but have children and grandchildren who enjoy some areas of the Colorado Canyons NCA. I am pleased that the area will have some sort of management and I think that a modest fee is appropriate. I would be opposed to turning over management to a private company

Comments: Absolutely essential in Mack Ridge area to limit motorized access to BLM management needs and one road access (besides frontage road) probably west on end of Mack Ridge. Grazing permits should be "traded out" or otherwise reduced so area could "come back" biologically. Definitely not transferred or renewed past life-time of current holding. "Local Pass" or Pass exchange for say 2 days a year of working with bonafide trail maintained efforts or trash pick up days. For Mack/Loma/ Fruita and Redlands residents this is part of your backyard. 3-5 remote hike-in only overnight camp spots on a prereserved (extra fee to anyone using) basis for full moons, holiday weekend, etc.

Comments: Jet skis should be banned - they spoil the experience for those of us who appreciate the natural quiet. The Ruby/Horsetheif Canyon Section should be designated Wild and Scenic River to help protect natural values and development in the view shed. Group sizes should be limited and campsites spread out to reduce trampling.

Comments: Rabbit Valley used to be fun, with many trails for ALL people. Stop micro-managing!

Comments: I am a geezer now and limited by emphysema. I hike with oxygen so I am not going very far. We often hear the argument that use must have access for the old, the halt and the lame, that's nonsense. There is a world of stuff by the side of the road all over the west. I saw it when I was young, now I am willing to sit back and give someone else a chance. But let them rough it. Realistically, I suppose we should develop the parks to concentrate people as much as possible and keep them out of the boonies.

Comments: I am extremely opposed to the collection of fees at public land areas. The management of his 
area can be achieved by community volunteer stewardship and in fact those programs are what have developed the recreational opportunities here and are what continue to provide free recreational management services

Comments: I strongly believe that the BLM should not be required to attempt to collect fees as a substitution for tax based funding for the basic management of public lands. Stewardship of these lands and resources is the responsibility of all of the citizens and should continue to be funded through the managing agency budget process- BLM should cooperate with other Federal and State agencies to set up management units where fees can be collected to operate and maintain facilities across administrative boundaries. This is especially recommended where the land ownership pattern is fragmented. BLM should obtain similar agreements with private owners and should seek enabling legislation as necessary.

Comments: I use BLM and USFS for extensive types of recreation. I do not feel user fees are appropriate for extensive use areas. Each year I pay $\$ 60$ for a NPS Pass and \$50 for a Colorado State Parks Pass for the use of their facilities - generally more intensive in nature (i.e. lakes, parking area, visitor center, toilets, etc.) I would not object to one fee pass for all federal - NPS, USFS, BLM, BOR, etc. but I don't think it is appropriate to be "nickel and dimed" at each location and I don't think it is right for BLM (or other federal land management agencies) to contract out work and use that as an excuse for charging user fees as well as taxes for public land management
Comments: Do not allow off road motorized vehicles - Do not allow ATVs

Comments: I have motorcycled in Rabbit Valley since I-70 opened taking many photographs in the whole area, in east Utah also, and thoroughly enjoying it

Comments: Why should I be free because I retired here from Broomfield, $\mathrm{CO}$, but would have to pay if I had not moved here or was a working person whose only time to come to come would be on the weekend?

Comments: Since becoming an NCA I understand that I cannot pick a rock up?! As a longtime (rock hound) mid 60's in N. Eng. I find this to be absurd. I have it in BLM print that I can pick up (even dig) up a rock or mineral in a WSA. This is a new burden on the local Grand Junction Gem and Mineral Club - of which I have been field trip chairperson for many years. Totally unnecessary, and if correct, this is one requirement of the statute that needs to be removed. Perhaps no digging would be more appropriate. 

As the Nation's principal conservation agency, the Department of the Interior has responsibility for most of our nationally owned public lands and natural resources. This responsibility includes fostering the sound use of our lands and water resources; protecting our fish, wildlife, and biological diversity; preserving the environmental and cultural values of our national parks and historical places; and providing for the enjoyment of life through outdoor recreation. The Department assesses our energy and mineral resources and works to ensure that their development is in the best interests of all our people by encouraging stewardship and citizen participation in their care. The Department also has a major responsibility for American Indian reservation communities.
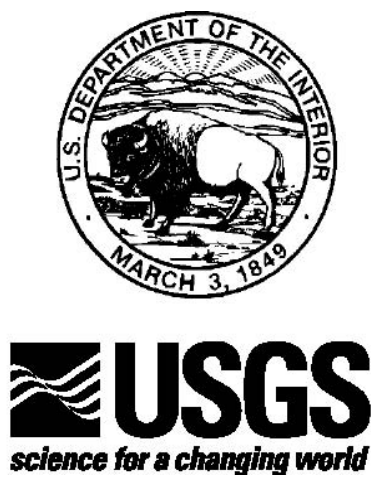